Cochrane Database of Systematic Reviews

\title{
Rocuronium versus succinylcholine for rapid sequence induction intubation (Review)
}

Tran DTT, Newton EK, Mount VAH, Lee JS, Wells GA, Perry JJ

Tran DTT, Newton EK, Mount VAH, Lee JS, Wells GA, Perry JJ.

Rocuronium versus succinylcholine for rapid sequence induction intubation.

Cochrane Database of Systematic Reviews 2015, Issue 10. Art. No.: CD002788.

DOI: 10.1002/14651858.CD002788.pub3.

www.cochranelibrary.com 
TABLE OF CONTENTS

HEADER 1

ABSTRACT

PLAIN LANGUAGE SUMMARY

SUMMARY OF FINDINGS

BACKGROUND

OBJECTIVES

METHODS

RESULTS

Figure 1.

Figure 2.

Figure 3.

Figure 4.

Figure 5.

Figure 6.

DISCUSSION

AUTHORS' CONCLUSIONS

ACKNOWLEDGEMENTS

REFERENCES

CHARACTERISTICS OF STUDIES

DATA AND ANALYSES

Analysis 1.1. Comparison 1 Rocuronium any dose versus succinylcholine, Outcome 1 Excellent versus other intubation conditions.

Analysis 1.2. Comparison 1 Rocuronium any dose versus succinylcholine, Outcome 2 Acceptable versus suboptimal intubation conditions.

Analysis 2.1. Comparison 2 Rocuronium specific dose versus succinylcholine, Outcome 1 Excellent versus other intubation conditions.

Analysis 2.2. Comparison 2 Rocuronium specific dose versus succinylcholine, Outcome 2 Acceptable versus suboptimal intubation conditions.

Analysis 3.1. Comparison 3 Rocuronium versus succinylcholine for induction agent, Outcome 1 Excellent versus other intubation conditions.

Analysis 3.2. Comparison 3 Rocuronium versus succinylcholine for induction agent, Outcome 2 Acceptable versus suboptimal intubation conditions.

Analysis 4.1. Comparison 4 Rocuronium versus succinylcholine with narcotic, Outcome 1 Excellent versus other intubation outcomes.

Analysis 4.2. Comparison 4 Rocuronium versus succinylcholine with narcotic, Outcome 2 Acceptable versus suboptimal intubation conditions.

Analysis 5.1. Comparison 5 Rocuronium versus succinylcholine without narcotic, Outcome 1 Excellent versus other intubation conditions.

Analysis 5.2. Comparison 5 Rocuronium versus succinylcholine without narcotic, Outcome 2 Acceptable versus suboptimal intubation conditions.

Analysis 6.1. Comparison 6 Comparison of children and adults, Outcome 1 Excellent versus other intubation conditions. ....... Analysis 6.2. Comparison 6 Comparison of children and adults, Outcome 2 Acceptable versus suboptimal intubation conditions.

Analysis 7.1. Comparison 7 Rocuronium versus succinylcholine in emergency intubation, Outcome 1 Excellent versus other intubation conditions.

Analysis 7.2. Comparison 7 Rocuronium versus succinylcholine in emergency intubation, Outcome 2 Acceptable versus suboptimal intubation conditions.

Analysis 8.1. Comparison 8 Rocuronium versus succinylcholine by blinding of outcome assessment, Outcome 1 Excellent versus other intubation conditions.

Analysis 8.2. Comparison 8 Rocuronium versus succinylcholine by blinding of outcome assessment, Outcome 2 Acceptable versus suboptimal intubation conditions.

ADDITIONAL TABLES

APPENDICES

1

2

3

4

4

4 
[Intervention Review]

\section{Rocuronium versus succinylcholine for rapid sequence induction intubation}

Diem TT Tran¹, Ethan K Newton ${ }^{1}$, Victoria AH Mount ${ }^{2}$, Jacques S Lee ${ }^{3}$, George A Wells ${ }^{4}$, Jeffrey J Perry 5

1Division of Cardiac Anesthesiology, Department of Anesthesia, The University of Ottawa Heart Institute, Ottawa, Canada. 2The Department of Family Medicine, Queen's University, Kingston, Canada. ${ }^{3}$ Emergency Department, Sunnybrook and Women's College Health Sciences Centre, Toronto, Canada. ${ }^{4}$ Department of Epidemiology and Community Medicine, University of Ottawa, Ottawa, Canada. ${ }^{5}$ Clinical Epidemiology Programme, The Ottawa Hospital, Ottawa, Canada

Contact address: Jeffrey J Perry, Clinical Epidemiology Programme, The Ottawa Hospital, 1053 Carling Avenue, F6 Clinical Epidemiology Programme, Ottawa, ON, K1Y 4E9, Canada. jperry@ohri.ca.

Editorial group: Cochrane Anaesthesia Group.

Publication status and date: New search for studies and content updated (no change to conclusions), published in Issue 10, 2015.

Citation: Tran DTT, Newton EK, Mount VAH, Lee JS, Wells GA, Perry JJ. Rocuronium versus succinylcholine for rapid sequence induction intubation. Cochrane Database of Systematic Reviews 2015, Issue 10. Art. No.: CD002788. DOI: 10.1002/14651858.CD002788.pub3.

Copyright $\odot 2015$ The Cochrane Collaboration. Published by John Wiley \& Sons, Ltd.

\section{A B S T R A C T}

\section{Background}

Patients often require a rapid sequence induction (RSI) endotracheal intubation technique during emergencies or electively to protect against aspiration, increased intracranial pressure, or to facilitate intubation. Traditionally succinylcholine has been the most commonly used muscle relaxant for this purpose because of its fast onset and short duration; unfortunately, it can have serious side effects. Rocuronium has been suggested as an alternative to succinylcholine for intubation. This is an update of our Cochrane review published first in 2003 and then updated in 2008 and now in 2015.

\section{Objectives}

To determine whether rocuronium creates intubating conditions comparable to those of succinylcholine during RSI intubation.

\section{Search methods}

In our initial review we searched all databases until March 2000, followed by an update to June 2007. This latest update included searching the Cochrane Central Register of Controlled Trials (CENTRAL; 2015, Issue 2), MEDLINE (1966 to February Week 2 2015), and EMBASE (1988 to February 142015 ) for randomized controlled trials (RCTs) or controlled clinical trials (CCTs) relating to the use of rocuronium and succinylcholine. We included foreign language journals and handsearched the references of identified studies for additional citations.

\section{Selection criteria}

We included any RCT or CCT that reported intubating conditions in comparing the use of rocuronium and succinylcholine for RSI or modified RSI in any age group or clinical setting. The dose of rocuronium was at least $0.6 \mathrm{mg} / \mathrm{kg}$ and succinylcholine was at least $1 \mathrm{mg} / \mathrm{kg}$.

\section{Data collection and analysis}

Two authors (EN and DT) independently extracted data and assessed methodological quality for the 'Risk of bias' tables. We combined the outcomes in Review Manager 5 using a risk ratio (RR) with a random-effects model.

\section{Main results}

The previous update (2008) had identified 53 potential studies and included 37 combined for meta-analysis. In this latest update we identified a further 13 studies and included 11, summarizing the results of 50 trials including 4151 participants. Overall, succinylcholine was superior to rocuronium for achieving excellent intubating conditions: RR 0.86 ( $95 \%$ confidence interval $(\mathrm{Cl}) 0.81$ to $0.92 ; \mathrm{n}=4151)$ and 
clinically acceptable intubation conditions (RR 0.97, 95\% Cl 0.95 to $0.99 ; n=3992,48$ trials). A high incidence of detection bias amongst the trials coupled with significant heterogeneity provides moderate-quality evidence for these conclusions, which are unchanged from the previous update. Succinylcholine was more likely to produce excellent intubating conditions when using thiopental as the induction agent: RR 0.81 ( $95 \% \mathrm{Cl}: 0.73$ to $0.88 ; n=2302,28$ trials). In the previous update, we had concluded that propofol was the superior induction agent with succinylcholine. There were no reported incidences of severe adverse outcomes. We found no statistical difference in intubation conditions when succinylcholine was compared to $1.2 \mathrm{mg} / \mathrm{kg}$ rocuronium; however, succinylcholine was clinically superior as it has a shorter duration of action.

\section{Authors' conclusions}

Succinylcholine created superior intubation conditions to rocuronium in achieving excellent and clinically acceptable intubating conditions.

\section{PLAIN LANGUAGE SUMMARY}

\section{Comparison of two muscle relaxants, rocuronium and succinylcholine, to facilitate rapid sequence induction intubation}

\section{Review question}

Which drug (rocuronium or succinylcholine) is better at providing excellent conditions to quickly insert breathing tubes into participants of all ages for elective and emergency situations?

\section{Background}

In emergency situations some people need a general anaesthetic with an endotracheal tube (a tube to help them breathe). It is important to have fast-acting medications to allow physicians to complete this procedure quickly and safely. Currently, the medication used most frequently to relax muscles is succinylcholine. Succinylcholine is fast-acting and lasts for only a few minutes, which is very desirable in this setting. However, some people cannot use this medication as it can cause serious salt imbalances or reactions, so an equally effective medication without these side effects would be advantageous. One possible alternative medication is rocuronium, a muscle relaxant with fewer side effects but longer duration of action. This review compares the quality of intubation conditions (the ease with which physicians can quickly and safely pass the endotracheal tube) between rocuronium and succinylcholine in all ages and varying clinical situations.

\section{Study characteristics}

We included in the review controlled trials from 1966 to February 2015 involving participants of all ages needing rapid intubation using rocuronium and succinylcholine. The minimum dose of rocuronium given was $0.6 \mathrm{mg} / \mathrm{kg}$ and succinylcholine was $1 \mathrm{mg} / \mathrm{kg}$. We have combined the results of 50 trials, with a total of 4151 participants, which compared the effectiveness of succinylcholine versus rocuronium on intubation conditions. No major side effects from use of the drugs were reported.

\section{Key results}

We have found that rocuronium is slightly less effective than succinylcholine for creating excellent and acceptable intubation conditions. Rocuronium should therefore only be used as an alternative to succinylcholine when it is known that succinylcholine should not be used and a more prolonged intubation is expected.

\section{Quality of evidence}

The level of evidence is of moderate GRADE due to imperfect study designs and varying techniques used across trials . 
SUMMARY OF FINDINGS

\section{Summary of findings for the main comparison. Rocuronium any dose versus succinylcholine for rapid sequence induction intubation}

\section{Rocuronium any dose versus succinylcholine for rapid sequence induction intubation}

Patient or population: People requiring rapid sequence induction intubation

Settings: Elective Operating Room, Emergency Room or Intensive Care Unit

Intervention: Rocuronium, any dose

Comparison: Succinylcholine

\begin{tabular}{|c|c|c|c|c|c|c|}
\hline \multirow[t]{3}{*}{ Outcomes } & \multicolumn{2}{|c|}{$\begin{array}{l}\text { Illustrative comparative risks }{ }^{\star} \\
(95 \% \mathrm{CI})\end{array}$} & \multirow{3}{*}{$\begin{array}{l}\text { Relative ef- } \\
\text { fect } \\
(95 \% \mathrm{CI})\end{array}$} & \multirow{3}{*}{$\begin{array}{l}\text { No of Partici- } \\
\text { pants } \\
\text { (studies) }\end{array}$} & \multirow{3}{*}{$\begin{array}{l}\text { Quality of the } \\
\text { evidence } \\
\text { (GRADE) }\end{array}$} & \multirow[t]{3}{*}{ Comments } \\
\hline & $\begin{array}{l}\text { Assumed } \\
\text { risk }^{1}\end{array}$ & $\begin{array}{l}\text { Corresponding } \\
\text { risk }\end{array}$ & & & & \\
\hline & $\begin{array}{l}\text { Succinyl- } \\
\text { choline }\end{array}$ & $\begin{array}{l}\text { Rocuronium any } \\
\text { dose } 2\end{array}$ & & & & \\
\hline \multirow{2}{*}{$\begin{array}{l}\text { Excellent ver- } \\
\text { sus other in- } \\
\text { tubation con- } \\
\text { ditions }\end{array}$} & 76 per 100 & 65 per 100 & \multirow{2}{*}{$\begin{array}{l}\text { RR } 0.86 \\
\text { (0.81 to } 0.92)\end{array}$} & \multirow{2}{*}{$\begin{array}{l}4151 \\
\text { (50 RCTs) }\end{array}$} & \multirow{2}{*}{$\begin{array}{l}\oplus \oplus \oplus \odot \\
\text { MODERATE }\end{array}$} & \multirow{2}{*}{$\begin{array}{l}\text { Risk of bias: } 50 \% \text { of the studies were at high risk for detection } \\
\text { bias because the outcome assessor was not blinded to the fas- } \\
\text { ciculations caused by succinylcholine. } \\
\text { Inconsistency: High statistical heterogeneity in the studies } \\
\text { could not be explained by subgroup analyses. However we did } \\
\text { not downgrade because exclusion of trials contributing to het- } \\
\text { erogeneity did not significantly change the direction or size of } \\
\text { effect. }\end{array}$} \\
\hline & & (01 lo 69$)$ & & & & \\
\hline
\end{tabular}

*The basis for the assumed risk (e.g. the median control group risk across studies) is provided in footnotes. The corresponding risk (and its $95 \%$ confidence interval) is based on the assumed risk in the comparison group and the relative effect of the intervention (and its $95 \% \mathrm{Cl}$ ).

CI: Confidence interval; RR: risk ratio; RCT: randomized controlled trial

GRADE Working Group grades of evidence

High quality: Further research is very unlikely to change our confidence in the estimate of effect.

Moderate quality: Further research is likely to have an important impact on our confidence in the estimate of effect and may change the estimate.

Low quality: Further research is very likely to have an important impact on our confidence in the estimate of effect and is likely to change the estimate.

Very low quality: We are very uncertain about the estimate.

1 Assumed risk is the average number of excellent intubations with succinylcholine.

2Rocuronium minimum dose $0.6 \mathrm{mg} / \mathrm{kg}$. Succinylcholine minimal dose is $1 \mathrm{mg} / \mathrm{kg}$. 


\section{B A C K G R O U N D}

\section{Description of the condition}

Patients who need endotracheal intubation in the emergency department or the operating room often require a rapid sequence induction (RSI) technique to protect against aspiration of gastric contents or to facilitate urgent airway protection in cases of imminent airway closure, haemodynamic instability, failing gas exchange and urgent surgical emergencies (Huizinga 1992; McCourt 1998; Stollings 2014).

\section{Description of the intervention}

The RSI technique involves the rapid sequential administration of medications (including a sedative, induction anaesthetic and a muscle relaxant, with or without narcotic) followed by endotracheal intubation within one minute of administering the muscle relaxant. In emergency situations, intubation is often required in unstable situations with the potential of haemodynamic instability. This frequently requires modification of the rapid sequence induction for the individual patient, with the goal of securing a patent airway as safely and quickly as possible.

\section{How the intervention might work}

Succinylcholine, a depolarizing muscle relaxant, is the most common agent used for a RSI technique in both the controlled and emergency settings (Weiss 1997). Succinylcholine has been the preferred muscle relaxant because it has a rapid onset of 40 to 60 seconds and a short duration, lasting only six to 10 minutes (Combs 1994). Succinylcholine's depolarizing action can lead to hyperkalaemia, possibly inducing fatal cardiac arrhythmias (Combs 1994; Schreiber 2005; Sullivan 1994). As a result, It is contraindicated in patients with major burns (beyond 48 hours), major crush injuries (beyond 48 hours), severe abdominal sepsis, denervation syndromes (such as amyotrophic lateral sclerosis or Guillain Barré Syndrome), muscular dystrophy and major nerve or spinal cord injuries (Martyn 2006). It is also contraindicated in patients with known hyperkalaemia, a history of malignant hyperthermia or previous allergic reaction to succinylcholine (Lebowitz 1989). Succinylcholine use has also been associated with variable increases in intracranial pressure (Minton 1986) and to a lesser extent intraocular pressure (Vinik 1999), and should be administered with drugs that help mitigate these side effects.

Alternative agents, among others, include pancuronium, vecuronium, atracurium and cisatracurium; however, none achieve acceptable intubating conditions as rapidly as succinylcholine (Mazurek 1998). Rocuronium is a steroid-based non-depolarizing muscle relaxant, which has been proposed for creating intubating conditions similar to those of succinylcholine. The duration of action is longer, lasting 37 to 72 minutes with standard doses (Magorian 1993). The only absolute contraindication to rocuronium is allergy. Care must be taken with people who have myasthenia gravis or myasthenic syndrome, hepatic disease, neuromuscular disease, carcinomatosis, or severe cachexia, as the duration of action may be profoundly increased (Stollings 2014).

\section{Why it is important to do this review}

There have been many studies looking at the equivalence of rocuronium and succinylcholine, with conflicting outcomes. It has been suggested that inconsistencies in the use of narcotics, the sedative propofol, or the dose of rocuronium administered may have accounted for these differences (Magorian 1993). No previous systematic review comparing the intubation conditions created by rocuronium and succinylcholine had been published prior to our initial review (Perry 2003). This review allows for subgroup analyses to assess for sources of inconsistency between studies. This latest update is important, given that several additional studies have been published since our last update (Perry 2008).

\section{O B J E C T IVES}

To determine whether rocuronium creates intubating conditions comparable to those of succinylcholine during RSI intubation.

\section{METHODS}

\section{Criteria for considering studies for this review}

\section{Types of studies}

We included all randomized clinical trials (RCTs) and controlled clinical trials (CCTs) meeting the following inclusion criteria:

1. the study reported a score of intubation conditions as one of the main outcomes;

2. the study compared rocuronium to succinylcholine;

3. the dose of rocuronium administered was at least $0.6 \mathrm{mg} / \mathrm{kg}$ and the dose of succinylcholine was at least $1 \mathrm{mg} / \mathrm{kg}$ (Danzl 2000).

\section{Types of participants}

We included in the analysis men, women and children of any age who underwent a rapid sequence induction (RSI), or modified RSI, intubation either electively or emergently. We defined a modified RSI as using both a sedative and a muscle relaxant followed by intubation, with either a delay between the administration of the two drugs or a delay of more than 60 seconds between the administration of the muscle relaxant and the intubation attempt, or both.

\section{Types of interventions}

All of the trials we included in this review compared rocuronium to succinylcholine for neuromuscular blockade. The sedative used for induction anaesthesia was thiopental, propofol, benzodiazepines, ketamine or etomidate. We accepted trials with or without narcotic agents. Additional medications allowed in this review were the use of pre-treatment sedatives (e.g. low-dose benzodiazepines).

\section{Types of outcome measures}

We assessed intubating conditions using the Goldberg scale (see Table 1), (Goldberg 1989; Weiss 1997). This is a widely used scale (although not always attributed to Goldberg et al.) that allocates a score for each of: ease of intubation, vocal cord movement, and patient response to intubation (diaphragmatic movement, coughing or bucking). This scale gives a total point value of 12 , in which three represents excellent; four to six represents good; seven to nine represents poor, and 10 to 12 represents impossible or inadequate intubation conditions. Excellent intubation conditions had a score of three which means there must have been good conditions recorded by the operator, open vocal cords that were immobile, and no response by the patient to intubation. We converted trials to this scale if this had not been directly reported, but sufficient detail was available to do so. We compared 
rocuronium with succinylcholine by comparing the proportions of excellent intubation scores and the proportions of clinically acceptable intubation scores (good or excellent).

\section{Primary outcomes}

The primary outcome assessed was excellent intubation conditions created during RSI (or modified RSI) comparing rocuronium with succinylcholine.

\section{Secondary outcomes}

The secondary outcome assessed was clinically acceptable (excellent or good) intubation conditions created during RSI (or modified RSI) comparing rocuronium with succinylcholine.

\section{Search methods for identification of studies}

\section{Electronic searches}

In our initial systematic review (Perry 2003) we searched all databases until March 2000. We reran the search to 2007 in our first update (Perry 2008). For this latest updated version we searched the Cochrane Central Register of Controlled Trials (CENTRAL; 2015, Issue 2), MEDLINE (1966 to February 142015 ), and EMBASE (1988 to February 142015 ) to identify all clinical trials relating to the use of rocuronium and succinylcholine during RSI. We used the validated RCT filter for the search (Haynes 1994).

Please refer to Appendix 1 (MEDLINE), Appendix 2 (EMBASE) and Appendix 3 (CENTRAL) for our search strategies.

The local director of our library services reviewed our search strategy.

\section{Searching other resources}

We handsearched the references of included trials to add any citations missed by the electronic searches. We did not apply any language restrictions to the search.

\section{Data collection and analysis}

We combined all trials using Review Manager 5 software (RevMan 5.3). We produced the 'Summary of findings' table using GRADEpro software (GRADEpro 2015).

\section{Selection of studies}

We retrieved studies by searching by title or abstract. Two independent appraisers (JP, JL, VS, EN or DT) reviewed relevant articles using specific criteria defined in 'Types of studies'. We measured Inter-rater agreement Kappa statistics. We resolved all disagreements by consensus. If we could not reach consensus, then a third author (GW or JP) was available to give a final decision.

\section{Data extraction and management}

Two authors (JP, JL, VS, EN, or DT) independently extracted data using standardized data collection forms. We converted intubation conditions to the Goldberg scale (four levels) if required and if adequate information was provided to do so. Rocuronium was compared to succinylcholine by comparing the proportion of excellent intubation scores to non-excellent scores and the proportion of clinically acceptable scores (good or excellent) to the proportion of non-clinically acceptable scores (poor or impossible). We resolved disagreements by consensus, with both extractors referring to the original text together, or by consulting a third author (JP). All data presented were from published literature only. Exact numbers for intubating conditions were provided by the authors for Sluga 2005.

\section{Assessment of risk of bias in included studies}

In this update, DT and EN reviewed and assessed all trials included in the review using the 'Risk of bias' tool.

\section{Measures of treatment effect}

We calculated dichotomous variables as risk ratios (RRs) for both excellent and acceptable intubation conditions, both with $95 \%$ confidence intervals $(95 \% \mathrm{Cls})$ with a random-effects model.

\section{Unit of analysis issues}

The unit of analysis was the intubation scores provided by each of the included trials. Sometimes the distribution of scores was provided only in graphical format, in which case the authors had to extrapolate from the graphs manually. We converted intubations scores when available to the Goldberg scale.

\section{Dealing with missing data}

We only included trials if they reported intubating conditions as a scale or in components which could be converted to the Goldberg scale. We performed analysis on an intention-to-treat basis. We conducted subgroup analyses for applicable trials and reported details of excluded information in included trials.

\section{Assessment of heterogeneity}

We assessed statistical heterogeneity by using the I statistic with thresholds of $25 \%, 50 \%$ and $75 \%$ to indicate mild, moderate and high degrees of heterogeneity respectively (Higgins 2003). Visual inspection was performed of the graphic representation of the trials with their $95 \% \mathrm{Cls}$. We explored the causes of significant heterogeneity with subgroup analyses and influence analyses.

\section{Assessment of reporting biases}

We performed this by visual inspection of a funnel plot of the included trials, to assess for publication bias.

\section{Data synthesis}

We conducted a meta-analysis for the primary outcome of excellent intubation conditions and the secondary outcome of clinically acceptable conditions (where data were available) using Review Manager 5 software (RevMan 5.3). For trials comparing multiple drugs, we used only data points involving succinylcholine and rocuronium with the same induction agents.

\section{Subgroup analysis and investigation of heterogeneity}

A priori subgroup analysis for the outcome of excellent intubation conditions compared the following groups: simulated RSI (i.e. the neuromuscular-blocking agent is administered immediately following the sedative and conditions evaluated within 60 seconds) versus modified RSI; induction agent; use versus non-use of a narcotic; doses of rocuronium $(0.6,0.9$, or $1.2 \mathrm{mg} / \mathrm{kg}$ ); adult versus paediatric age groups; and emergency intubations (added in the previous update, Perry 2008). 
After we completed the assessment of bias, we conducted subgroup analyses according to categorization of blinding of outcome assessment, to further identify the source of heterogeneity.

\section{Sensitivity analysis}

In order to assess their impact on the effect direction, size and precision of the summary estimate,we conducted analyses excluding trials in turn that:

1. contributed most to heterogeneity;

2. were most heavily weighted;

3. showed marked differences in intubation sequence (such as very short time between delivery of muscle relaxant and intubation).

\section{Summary of findings table}

We imported data from Review Manager 5 into the online GRADEpro software to produce the 'Summary of findings' table. The assumed risk population was set as the average incidence of excellent intubating conditions in the pooled control group. There is one primary outcome for which we assessed the overall quality of evidence using GRADE methodology by starting at a high level of evidence for RCTs and downgrading for serious deficiencies in the categories of study limitations, indirectness, imprecision, inconsistency and publication bias.

\section{RES U L T S}

\section{Description of studies}

\section{Results of the search}

In our previous update (Perry 2008) we identified 53 studies and included 37 . For this update we identified 13 new studies. All the included studies are RCTs, with the exception of one CCT identified for this update (De Almeida 2009).

\section{Included studies}

We include 11 new trials in this review (Abu-Halaweh 2007; Ali 2008; Belyamani 2008; De Almeida 2009; Iqbal 2013; Kulkarni 2010; Kwon 2013; Marsch 2011; Tripathi 2010; Singh 2011; Sorensen 2012; ) (see table Characteristics of included studies). Two articles identified from the previous update were translated and the results incorporated in this update (Mencke 2005; Türkmen 2004) (Figure 1). The revised search identified 66 studies, of which 52 met the inclusion criteria. Two of these were duplicate publications (Dubois 1991a; Mirakhur 1994a) and were therefore included as secondary references. 
Figure 1. Search flow diagram for this update from July 2007 to February 2015

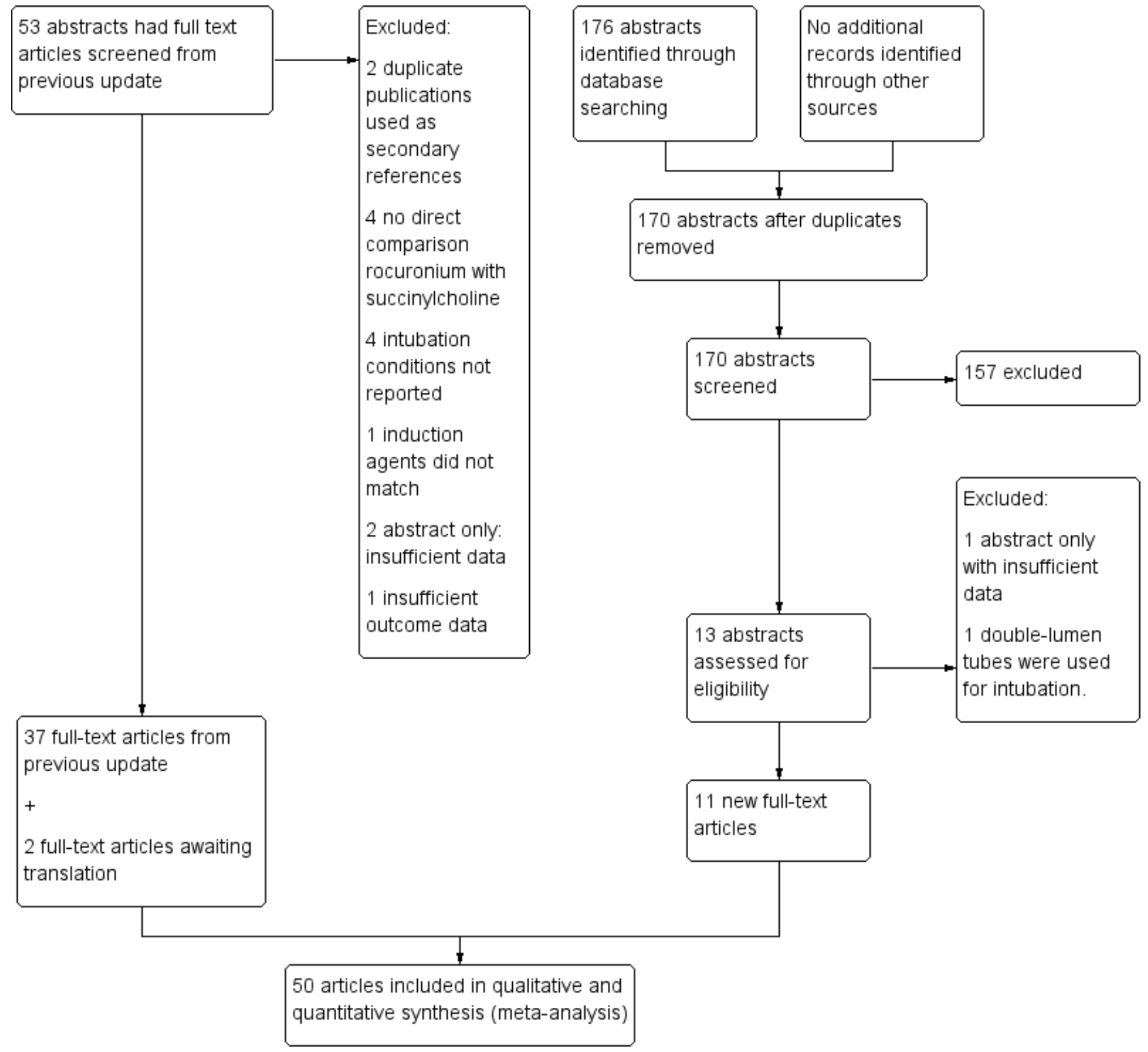

We now include 50 trials incorporating results from 4151 individuals in this updated review.

\section{Rationale for excluded information from included studies}

Andrews 1999 and McCourt 1998 are two of the largest trials conducted to date. Both trials had planned to conduct interim analyses at the halfway mark, and in both cases the steering committees decided to drop the lower dose rocuronium, as it was shown to be inferior to the larger dose (Dubois 1995). Neither trial reported the results of the low-dose control groups. Hence, the data for the low-dose rocuronium are not included in this metaanalysis. In addition, Sparr 1996b used four different treatment groups with only one control group. Only one of the four treatment groups using rocuronium was appropriately controlled for, i.e. the succinylcholine group which used thiopentone without alfentanyl. Hence we have not included the rocuronium groups with propofol or alfentanyl in this meta-analysis (no control group). Belyamani 2008 performed a trial assessing the benefit of ephedrine on intubating conditions when using either succinylcholine or rocuronium. Of the four treatment groups, we used only the data from the two control groups in this analysis. De Almeida 2009 enrolled morbidly obese participants given different doses of muscle relaxant based on ideal body weight versus total body weight. We have included only data for the two groups dosed for total body weight in this analysis, because the ideal body weight groups would have lower drug levels than those specified in the inclusion criteria. The second trial to involve emergency intubations (Marsch 2011), involved either propofol or etomidate as an induction agent. The authors did not provide separate data for the two groups of participants and we therefore did not include this trial in the induction agent analysis. The figures and tables in Türkmen 2004 were unavailable, and we were therefore able to include only data points for excellent intubation conditions. 


\section{Excluded studies}

We excluded two of the 13 new studies identified in this update (Misiolek 2009; Stourac 2013).

We have excluded a total of 14 studies, for the reasons detailed in the Characteristics of excluded studies

\section{Studies awaiting classification}

There are no studies awaiting classification.

\section{Ongoing studies}

There are no ongoing studies

\section{Risk of bias in included studies}

Figure 2 summarizes the findings in the four domains of random sequence generation, allocation concealment, blinding of outcome assessment and completeness of data.

Figure 2. Risk of bias graph: review authors' judgements about each risk of bias item presented as percentages across all included studies

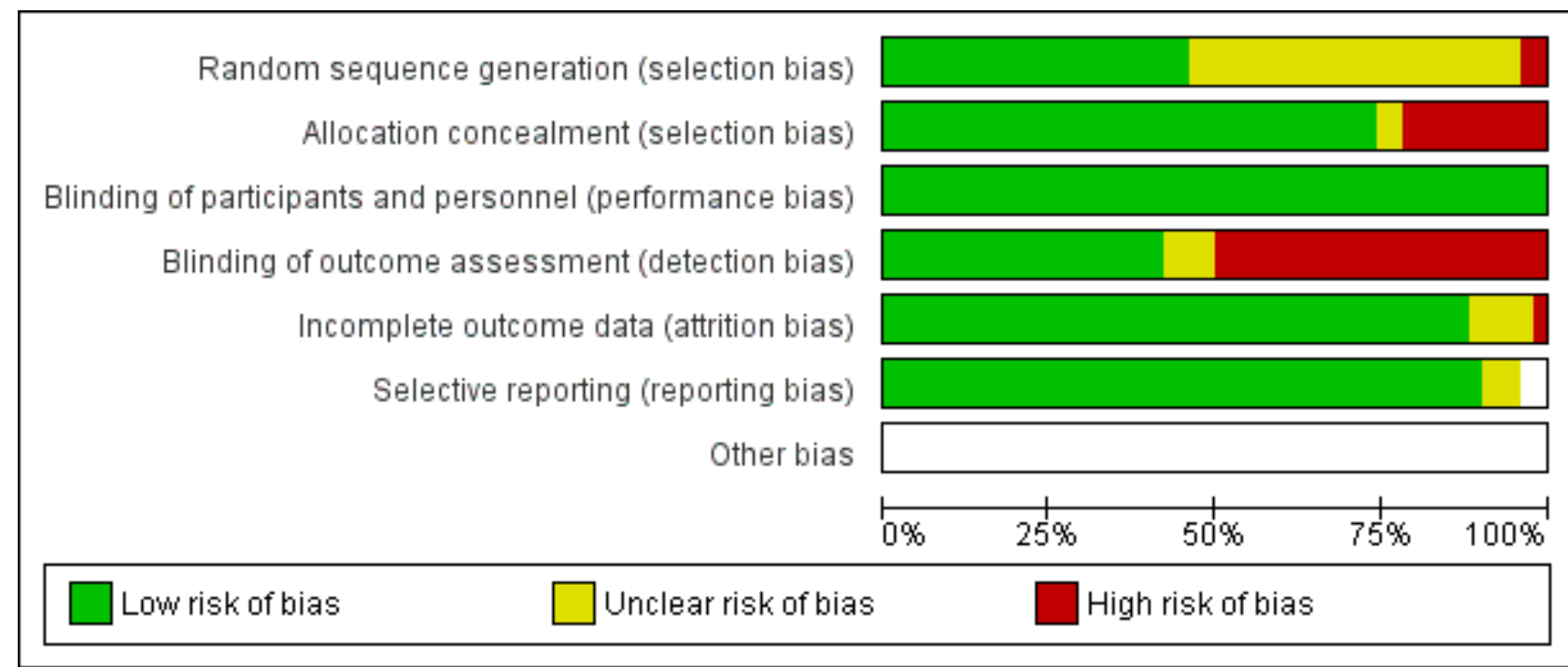

\section{Allocation}

All but one of the trials (De Almeida 2009) was described as a randomized control trial. However, the exact method of randomization was not always described. We rated two of the 50 included trials at high risk of bias for allocation, due to lack of randomization (De Almeida 2009) and randomization by arrival sequence for surgery (Koroglu 2002).

\section{Blinding}

The most prevalent area of high risk of bias was blinding of outcome assessment, resulting in downgrading of the quality of evidence to moderate. Although many investigators blinded the intubator to the medication injected, $50 \%$ did not blind the assessor to the obvious effects of the drugs (Figure 3). Succinylcholine causes very discernible fasciculations (muscle twitches) that can be observed by the intubator, unblinding the study drug and bias assessment of the primary outcome. Please refer to individual 'Risk of bias' tables for specific details of each trial . 
Figure 3. Risk of bias summary: review authors' judgements about each risk of bias item for each included trial

\begin{tabular}{|c|c|c|c|c|c|c|c|}
\hline & 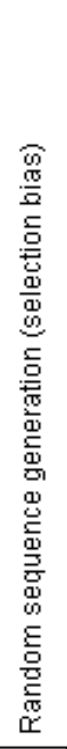 & 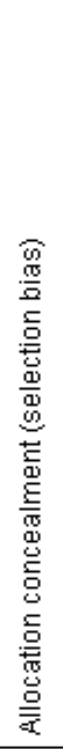 & 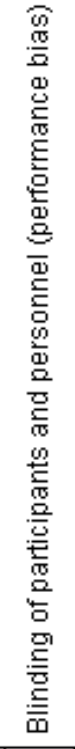 & 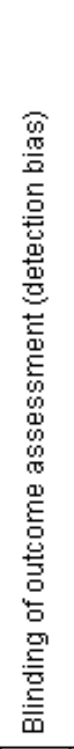 & 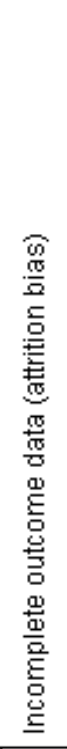 & 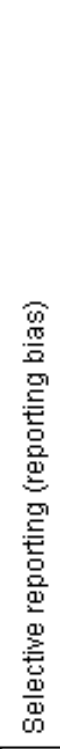 & 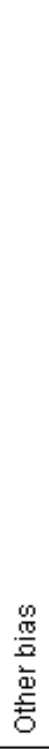 \\
\hline Abdulatif 1996 & $\odot$ & $\odot$ & + & $\odot$ & + & + & \\
\hline Abu-Halaweh 2007 & $\odot$ & $\odot$ & + & + & + & + & \\
\hline Alanoglu 2006 & $\odot$ & $\odot$ & 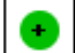 & $?$ & $\odot$ & + & \\
\hline Ali 2008 & $?$ & $?$ & + & + & $?$ & $?$ & \\
\hline Alvarez Rios1997 & $?$ & $\theta$ & + & $\theta$ & + & $\odot$ & \\
\hline Andrews 1999 & + & + & + & + & $\odot$ & $\odot$ & \\
\hline Belyamani 2008 & $\odot$ & + & 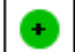 & + & $\odot$ & + & \\
\hline Cheng 2002 & + & + & + & + & + & + & \\
\hline Chiu 1999 & $?$ & + & + & + & + & + & \\
\hline Chung 2001 & $?$ & $\theta$ & + & O & + & + & \\
\hline Cooper 1992 & $?$ & $?$ & + & - & $\odot$ & + & \\
\hline De Almeida 2009 & C & $\theta$ & + & O & + & + & \\
\hline Dubois 1995 & + & + & + & + & $?$ & $?$ & \\
\hline Giudice 1998 & $?$ & - & + & - & + & + & \\
\hline Iqbal 2013 & $?$ & + & + & + & + & + & \\
\hline Koroglu 2002 & $\Theta$ & - & + & O & $?$ & + & \\
\hline Kulkarni 2010 & $?$ & $\theta$ & + & $\theta$ & + & + & \\
\hline Kwon 2013 & $?$ & + & + & $?$ & + & + & \\
\hline Lam 2000 & $\odot$ & + & + & - & $\odot$ & + & \\
\hline Larsen 2005 & $\odot$ & + & 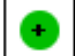 & $\odot$ & $\odot$ & $\odot$ & \\
\hline
\end{tabular}


Figure 3. (Continued)

\begin{tabular}{|c|c|c|c|c|c|c|}
\hline Larsen 2005 & $\odot$ & + & + & + & $\odot$ & $\odot$ \\
\hline Latorre 1996 & $?$ & $\odot$ & $\odot$ & $\odot$ & $\odot$ & $\odot$ \\
\hline Le Corre 1999 & $?$ & + & + & + & $\Theta$ & $?$ \\
\hline Magorian 1993 & $?$ & $\odot$ & + & $\odot$ & $\odot$ & $\odot$ \\
\hline Malik 2004 & $?$ & 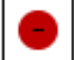 & + & $\odot$ & + & 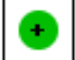 \\
\hline Marsch 2011 & $\odot$ & 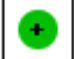 & + & $\odot$ & + & + \\
\hline Mazurek 1998 & + & + & + & + & $\oplus$ & + \\
\hline McCourt 1998 & + & 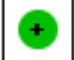 & + & + & + & + \\
\hline Mencke 2005 & + & + & + & $\odot$ & + & + \\
\hline Mencke 2006 & + & 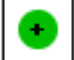 & + & + & + & + \\
\hline Mitra 2001 & $?$ & + & + & + & $\odot$ & + \\
\hline Naguib 1994 & $?$ & + & + & $?$ & + & + \\
\hline Naguib 1997 & $?$ & + & + & $\odot$ & + & + \\
\hline Nelson 1997 & $\odot$ & 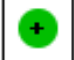 & + & + & $?$ & \\
\hline Patel 1995 & $?$ & $\odot$ & $\odot$ & $\odot$ & $\odot$ & $\odot$ \\
\hline Pühringer 1992 & $\odot$ & $\odot$ & $\odot$ & $\odot$ & $\odot$ & $\odot$ \\
\hline Singh 2011 & $\odot$ & 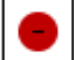 & $\odot$ & 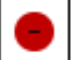 & $\odot$ & $\odot$ \\
\hline Sluga 2005 & $\odot$ & + & + & $\odot$ & + & + \\
\hline Sorensen 2012 & $\odot$ & $\odot$ & + & $\odot$ & $\odot$ & $\odot$ \\
\hline Sparr 1996a & $?$ & 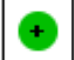 & $\odot$ & $\odot$ & $\odot$ & $\odot$ \\
\hline Sparr 1996b & $?$ & 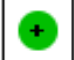 & $\odot$ & + & + & $\odot$ \\
\hline Stevens 1996 & $\odot$ & + & + & $\odot$ & $\odot$ & 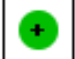 \\
\hline Stoddart 1998 & $\odot$ & $\odot$ & + & $\odot$ & $\odot$ & $\odot$ \\
\hline Tang 1996 & $?$ & $\odot$ & + & + & + & 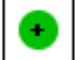 \\
\hline Tripathi 2010 & $?$ & 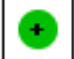 & + & $\odot$ & + & 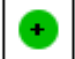 \\
\hline Tryba 1994 & $?$ & + & + & $\odot$ & $\odot$ & $\odot$ \\
\hline Turan 1999 & $?$ & $\odot$ & + & $?$ & + & + \\
\hline Türkmen 2004 & $?$ & + & + & $\odot$ & $?$ & \\
\hline Vinik 1999 & $?$ & $\odot$ & + & $\odot$ & + & + \\
\hline Weiss 1997 & + & + & + & + & $\odot$ & $\odot$ \\
\hline Yorukoglu 2003 & + & + & + & $\odot$ & $\odot$ & $\odot$ \\
\hline
\end{tabular}




\section{Incomplete outcome data}

Completeness of data was almost uniformly low-risk in the included trials, with the majority of them being complete.

\section{Selective reporting}

There were no concerns regarding selective reporting of results, as the outcome data were complete for all randomized participants in all included trials.

\section{Other potential sources of bias}

We assessed publication bias with a funnel plot. Visual inspection revealed an equal number of trials on either side of the effect estimate, although there was more scatter to the left indicating a paucity of trials in the lower right quadrant representing small unpublished trials favouring the use of rocuronium (Figure 4).

Figure 4. Funnel plot of comparison: Rocuronium any dose versus succinylcholine, outcome: Excellent versus other intubation conditions.

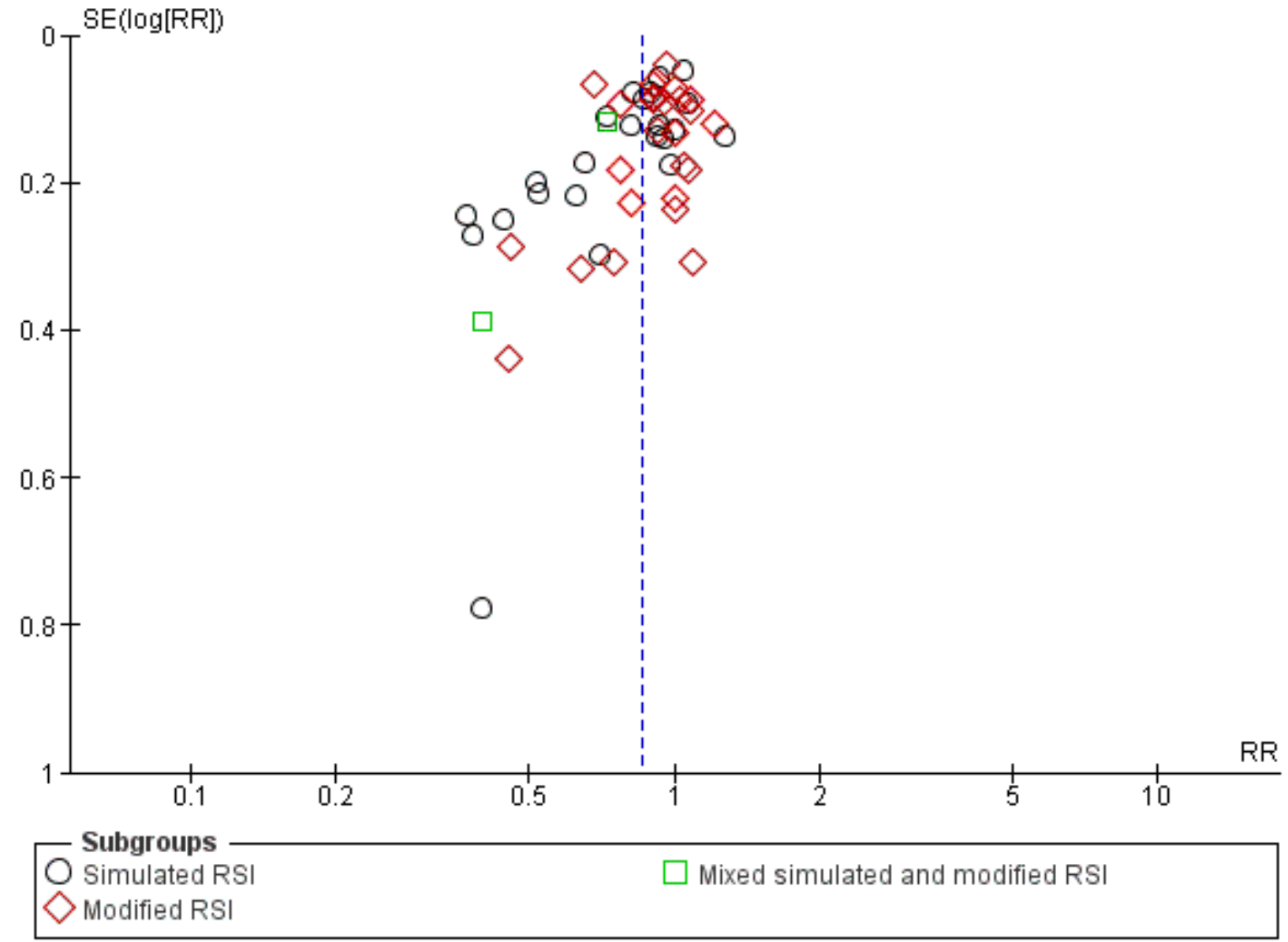

\section{Effects of interventions}

See: Summary of findings for the main comparison Rocuronium any dose versus succinylcholine for rapid sequence induction intubation

\section{Primary outcome of excellent intubation conditions}

There was a statistically significant risk ratio (RR) favouring succinylcholine in the comparison for the primary outcome of excellent intubating conditions, with a RR $0.86(95 \% \mathrm{Cl} 0.81$ to 0.92 ; participants $=4151 ;$ studies $=50 ;\left.\right|^{2}$ statistic $=72 \%$; Analysis 1.1$)$. The number needed to treat for an additional harmful outcome (NNTH) for this outcome was eight ( $95 \% \mathrm{Cl} 12$ to 6$)$. There was heterogeneity present in this comparison, as demonstrated graphically with the $95 \% \mathrm{Cls}$ for each trial. The $\mathrm{Chi}^{2}$ test for heterogeneity was significant (Figure 5). An analysis of the influence on heterogeneity demonstrated that no single trial, regardless of size, significantly altered the $\mathrm{I}^{2}$ statistic, with the exception of Kulkarni 2010 for the subgroup of modified RSI. These assessments and the following subgroup analyses were unable to explain the heterogeneity in the trials. However, this did not result in a downgrading of the quality of the evidence because we decided that the sources of heterogeneity were clinical variables which contributed to the generalizability of these results. 
Figure 5. Forest plot of comparison: 1 Rocuronium any dose versus succinylcholine, outcome: 1.1 Excellent versus other intubation conditions

\begin{tabular}{|c|c|c|c|c|c|c|c|c|}
\hline \multirow{2}{*}{$\frac{\text { Study or Subgroup }}{\text { 1.1.1 Simulated RSI }}$} & \multicolumn{2}{|c|}{ Rocuronium } & \multicolumn{2}{|c|}{ Succinylcholine } & Weight & Risk Ratio & \multicolumn{2}{|c|}{$\begin{array}{c}\text { Risk Ratio } \\
\text { M-H, Random, } 95 \% \mathrm{Cl}\end{array}$} \\
\hline & & & & & & & & \\
\hline Abu-Halaweh 2007 & 20 & 60 & 32 & 60 & $1.4 \%$ & $0.63[0.41,0.96]$ & 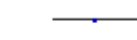 & \\
\hline Alanoglu 2006 & 57 & 60 & 54 & 59 & $3.2 \%$ & $1.04[0.94,1.14]$ & & \\
\hline Andrews 1999 & 88 & 133 & 103 & 139 & $2.9 \%$ & $0.89[0.76,1.04]$ & - & \\
\hline Belyamani 2008 & 2 & 20 & 5 & 20 & $0.2 \%$ & $0.40[0.09,1.83]$ & & \\
\hline Chiu 1999 & 13 & 15 & 14 & 15 & $2.3 \%$ & $0.93[0.73,1.18]$ & $\longrightarrow$ & 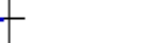 \\
\hline Chung 2001 & 20 & 29 & 19 & 27 & $1.7 \%$ & $0.98[0.69,1.38]$ & — & - \\
\hline De Almeida 2009 & 19 & 20 & 15 & 20 & $2.1 \%$ & $1.27[0.96,1.66]$ & & - \\
\hline Iqbal 2013 & 25 & 30 & 29 & 30 & $2.8 \%$ & $0.86[0.72,1.03]$ & - & \\
\hline Koroglu 2002 & 22 & 30 & 28 & 35 & $2.1 \%$ & $0.92[0.70,1.20]$ & 一 & - \\
\hline Larsen 2005 & 52 & 102 & 67 & 107 & $2.3 \%$ & $0.81[0.64,1.04]$ & & \\
\hline Malik 2004 & 28 & 30 & 30 & 30 & $3.2 \%$ & $0.93[0.83,1.05]$ & & \\
\hline Marsch 2011 & 109 & 201 & 102 & 200 & $2.7 \%$ & $1.06[0.88,1.28]$ & & 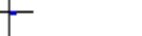 \\
\hline Mazurek 1998 & 7 & 13 & 10 & 13 & $0.9 \%$ & $0.70[0.39,1.26]$ & & - \\
\hline McCourt 1998 & 85 & 130 & 101 & 127 & $2.9 \%$ & $0.82[0.71,0.96]$ & - & \\
\hline Mencke 2005 & 13 & 60 & 34 & 60 & $1.0 \%$ & $0.38[0.23,0.65]$ & & \\
\hline Mencke 2006 & 16 & 76 & 42 & 74 & $1.2 \%$ & $0.37[0.23,0.60]$ & & \\
\hline Naguib 1997 & 17 & 20 & 9 & 10 & $2.1 \%$ & $0.94[0.72,1.25]$ & 一 & \\
\hline Sluga 2005 & 50 & 90 & 69 & 90 & $2.5 \%$ & $0.72[0.58,0.90]$ & 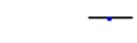 & \\
\hline Sparr 1996a & 15 & 25 & 23 & 25 & $1.8 \%$ & $0.65[0.46,0.92]$ & - & \\
\hline Sparr 1996b & 10 & 25 & 45 & 50 & $1.1 \%$ & $0.44[0.27,0.72]$ & - & \\
\hline Tryba 1994 & 48 & 60 & 16 & 20 & $2.3 \%$ & $1.00[0.78,1.29]$ & - & \\
\hline Weiss 1997 & 15 & 31 & 13 & 14 & $1.5 \%$ & $0.52[0.35,0.77]$ & - & \\
\hline Yorukoglu 2003 & 12 & 25 & 23 & 25 & $1.4 \%$ & $0.52[0.34,0.80]$ & 一 & \\
\hline Subtotal $(95 \% \mathrm{Cl})$ & & 1285 & & 1250 & $45.6 \%$ & $0.80[0.72,0.89]$ & $\bullet$ & \\
\hline Total events & 743 & & 883 & & & & & \\
\hline \multicolumn{9}{|c|}{$\begin{array}{l}\text { Heterogeneity: } \text { Tau }^{2}=0.04 ; \mathrm{Chi}^{2}=96.83, \mathrm{df}=22(\mathrm{P}<0.00001) ;\left.\right|^{2}=77 \% \\
\text { Test for overall effect: } Z=4.00(P<0.0001)\end{array}$} \\
\hline \multicolumn{9}{|l|}{ 1.1.2 Modified RSI } \\
\hline Alvarez Rios1997 & 18 & 20 & 19 & 20 & $2.8 \%$ & $0.95[0.79,1.13]$ & - & \\
\hline Cheng 2002 & 67 & 80 & 37 & 40 & $3.1 \%$ & $0.91[0.79,1.03]$ & 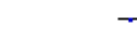 & \\
\hline Cooper 1992 & 30 & 40 & 39 & 40 & $2.7 \%$ & $0.77[0.64,0.93]$ & - & \\
\hline Dubois 1995 & 9 & 12 & 9 & 12 & $1.2 \%$ & $1.00[0.63,1.59]$ & $\longrightarrow$ & \\
\hline Giudice 1998 & 13 & 20 & 6 & 10 & $0.9 \%$ & $1.08[0.59,1.97]$ & & \\
\hline Kulkarni 2010 & 122 & 200 & 90 & 100 & $3.1 \%$ & $0.68[0.60,0.77]$ & - & \\
\hline Kwon 2013 & 5 & 20 & 11 & 20 & $0.5 \%$ & $0.45[0.19,1.07]$ & & \\
\hline Lam 2000 & 7 & 15 & 11 & 15 & $0.8 \%$ & $0.64[0.34,1.18]$ & & \\
\hline Latorre 1996 & 9 & 20 & 12 & 20 & $0.8 \%$ & $0.75[0.41,1.37]$ & & \\
\hline Le Corre 1999 & 28 & 30 & 26 & 30 & $2.8 \%$ & $1.08[0.91,1.28]$ & & - \\
\hline Magorian 1993 & 25 & 30 & 8 & 10 & $1.7 \%$ & $1.04[0.73,1.48]$ & - & \\
\hline Mitra 2001 & 18 & 20 & 20 & 20 & $2.8 \%$ & $0.90[0.76,1.07]$ & - & \\
\hline Naguib 1994 & 13 & 20 & 8 & 10 & $1.3 \%$ & $0.81[0.52,1.27]$ & & \\
\hline Nelson 1997 & 18 & 20 & 22 & 22 & $2.8 \%$ & $0.90[0.76,1.07]$ & - & \\
\hline Patel 1995 & 11 & 15 & 7 & 7 & $1.7 \%$ & $0.77[0.54,1.09]$ & & \\
\hline Pühringer 1992 & 17 & 20 & 8 & 10 & $1.7 \%$ & $1.06[0.74,1.52]$ & & \\
\hline Singh 2011 & 23 & 30 & 25 & 30 & $2.3 \%$ & $0.92[0.71,1.19]$ & & \\
\hline Sorensen 2012 & 27 & 29 & 20 & 26 & $2.4 \%$ & $1.21[0.96,1.53]$ & & - \\
\hline Stevens 1996 & 11 & 30 & 8 & 10 & $0.9 \%$ & $0.46[0.26,0.80]$ & & \\
\hline Stoddart 1998 & 27 & 30 & 25 & 30 & $2.6 \%$ & $1.08[0.88,1.32]$ & & \\
\hline Tang 1996 & 24 & 27 & 42 & 48 & $2.8 \%$ & $1.02[0.86,1.21]$ & & \\
\hline Tripathi 2010 & 47 & 50 & 49 & 50 & $3.3 \%$ & $0.96[0.89,1.04]$ & & \\
\hline Turan 1999 & 17 & 20 & 17 & 20 & $2.2 \%$ & $1.00[0.77,1.30]$ & & - \\
\hline Türkmen 2004 & 19 & 20 & 19 & 20 & $3.0 \%$ & $1.00[0.87,1.15]$ & & \\
\hline Vinik 1999 & 11 & 15 & 11 & 15 & $1.3 \%$ & $1.00[0.65,1.54]$ & & \\
\hline Subtotal (95\% Cl) & & 833 & & 635 & $51.4 \%$ & $0.92[0.85,0.99]$ & 4 & \\
\hline Total events & 616 & & 549 & & & & & \\
\hline \multicolumn{8}{|c|}{$\begin{array}{l}\text { Heterogeneity: } \operatorname{Tau}^{2}=0.02 ; \mathrm{Ch}^{2}=60.54, \mathrm{df}=24(\mathrm{P}<0.0001) ; \mathrm{I}^{2}=60 \% \\
\text { Test for overall effect: } Z=2.26(\mathrm{P}=0.02)\end{array}$} & \\
\hline \multicolumn{8}{|c|}{ 1.1.3 Mixed simulated and modified RSI } & \\
\hline ahdulatif 1996 & ค & 24 & 15 & 34 & $n$ ก\% & ก $\triangle \cap \cap 019 \cap 851$ & & \\
\hline
\end{tabular}




\section{Figure 5. (Continued)}

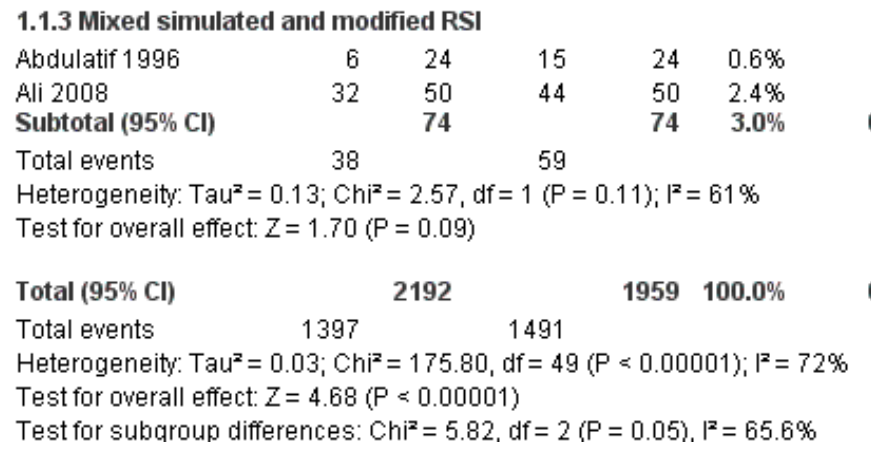

\section{Secondary outcome of clinically acceptable intubations}

We also found a statistically significant difference using the less stringent endpoint of clinically acceptable conditions (excellent or good, excluding poor or failed) with a RR 0.97 (95\% Cl 0.95 to 0.99 ; participants $=3992 ;$ studies $=48 ; 1^{2}$ statistic $=68 \%$; Analysis 1.2 .

\section{Subgroup analysis for the primary outcome of excellent intubation conditions: simulated versus modified RS I}

The subgroup which used a simulated RSI technique had a statistically significant RR favouring succinylcholine (RR 0.80, 95\% $\mathrm{Cl} 0.72$ to 0.89 ; participants $=2535 ;$ studies $=23 ; \mathrm{I}^{2}$ statistic $=$ $77 \%)$. The NNTH for this outcome was eight $(95 \% \mathrm{Cl} 12$ to 6$)$ and there was significant heterogeneity present. The subgroup using modified RSI also had significantly better intubation conditions in the succinylcholine group (RR $0.92,95 \% \mathrm{Cl} 0.85$ to 0.99 ; participants $=1468$; studies $=25 ;\left.\right|^{2}$ statistic $\left.=60 \%\right)$, and an NNTH of eight $(95 \%$ $\mathrm{Cl} 11$ to 5). There was also significant heterogeneity present for this subgroup. The subgroup using mixed simulated and modified RSI now includes two trials with no statistical difference observed.

\section{Subgroup analysis for the primary outcome of excellent intubation conditions: comparing the dose of rocuronium}

The subgroup using a dose of rocuronium of 0.6 to $0.7 \mathrm{mg} /$ $\mathrm{kg}$ had a RR favouring succinylcholine for excellent conditions (RR $0.80,95 \% \mathrm{Cl} 0.72$ to 0.88 ; participants $=2808$; studies $=39$;
$0.40[0.19,0.85]$

$0.73[0.58,0.92]$

$0.59[0.33,1.08]$

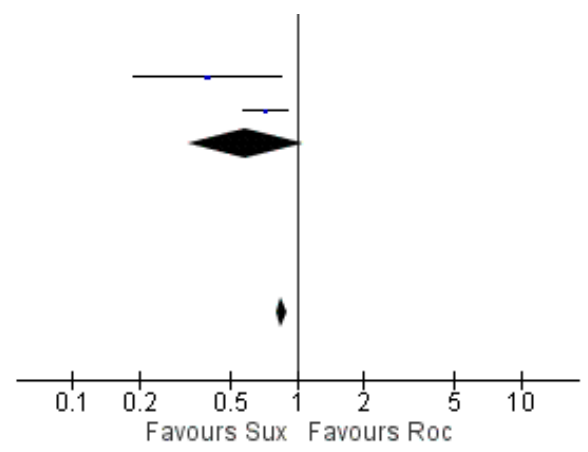

$1^{2}$ statistic $\left.=77 \%\right)$. The NNTH for this subgroup is six $(95 \% \mathrm{Cl}$ 7 to 5). There was significant heterogeneity between the trials. There were no statistical differences for excellent or acceptable intubation conditions in the group that received 0.9 to $1.0 \mathrm{mg} / \mathrm{kg}$ of rocuronium or the group that received $1.2 \mathrm{mg} / \mathrm{kg}$ of rocuronium. (Analysis 2.1)

\section{Subgroup analysis for the primary outcome of excellent intubation conditions: induction agents}

The thiopental subgroup displayed a statistical difference between succinylcholine and rocuronium for the outcome of excellent intubation conditions (RR $0.81,95 \% \mathrm{Cl} 0.73$ to 0.88 ; participants $=2302 ;$ studies $=28 ;\left.\right|^{2}$ statistic $\left.=81 \%\right)($ Figure 6$)$. The NNTH for this outcome was six $\left(95 \% \mathrm{Cl} 7\right.$ to 5). The $\mathrm{Chi}^{2}$ test for heterogeneity was significant. Further analysis of the thiopental subgroup compared the effect of thiopental when used with or without a narcotic. Succinylcholine created significantly better outcomes with narcotics ((RR $0.82,95 \% \mathrm{Cl} 0.73$ to 0.92 ; participants $=1300 ;$ studies $=17 ; 1^{2}$ statistic $=79 \% ;$ Analysis 4.1$)$ or without narcotics (RR 0.80, 95\% Cl 0.69 to 0.94; participants = 1002; studies $=12 ;\left.\right|^{2}$ statistic $=84 \%$; Analysis 5.1) in sequence with thiopental. In a change from our previous update, propofol as an induction agent is no longer associated with better intubating conditions. There were no trials that used benzodiazepines for induction, comparing rocuronium to succinylcholine. 
Figure 6. Forest plot of comparison: 3 Rocuronium versus succinylcholine for induction agent, outcome: 3.1 Excellent versus other intubation conditions

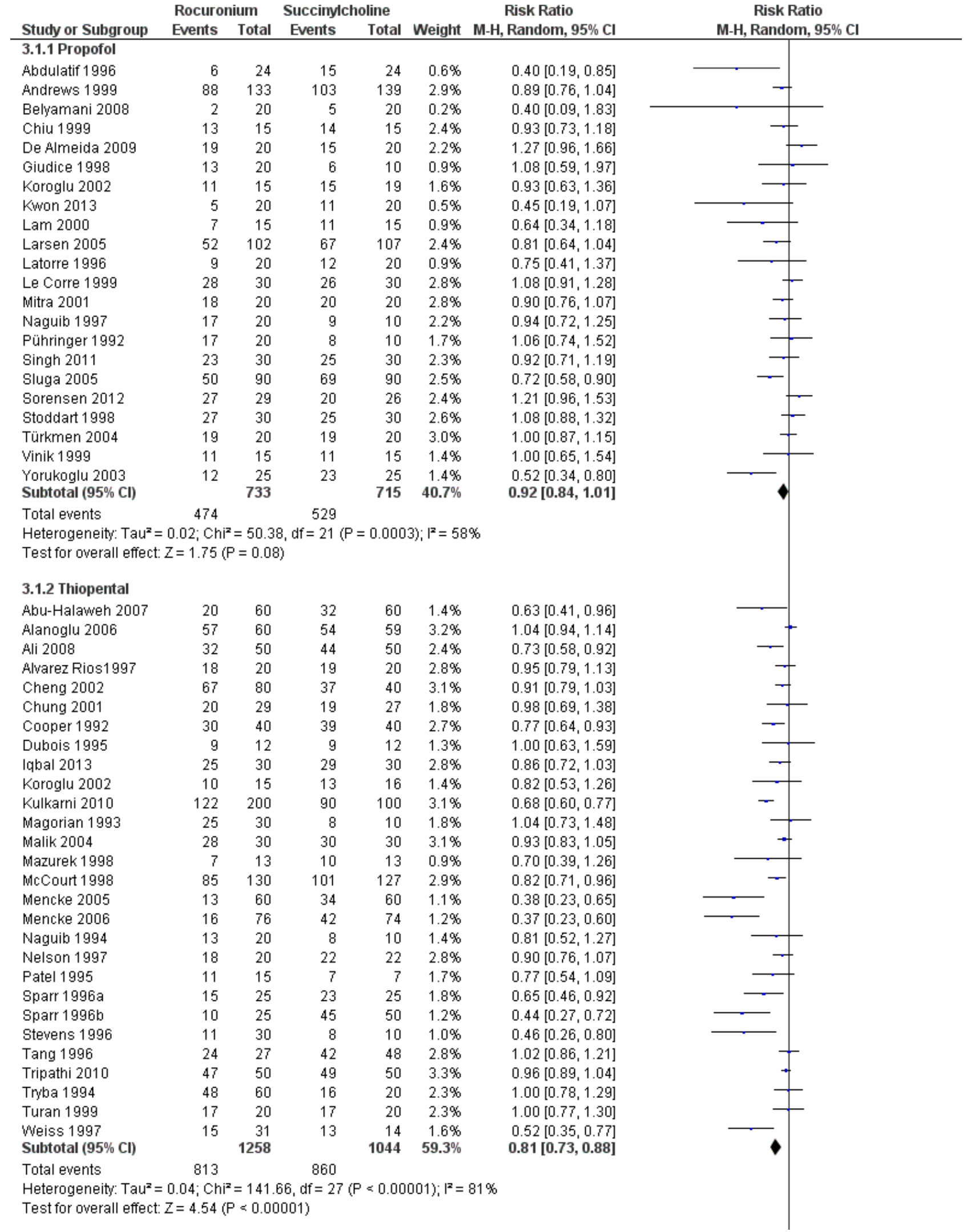


Figure 6. (Continued)

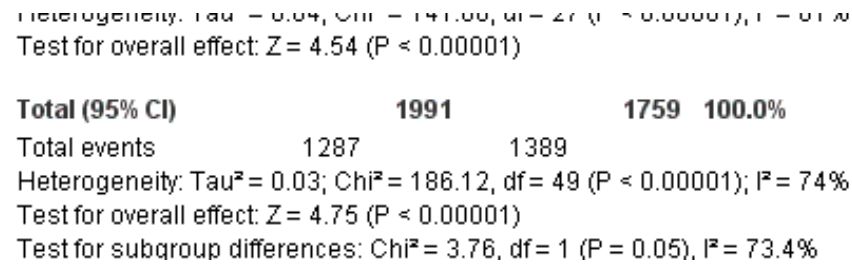

\section{Subgroup analysis for the primary outcome of excellent intubation conditions: use of narcotics}

Succinylcholine provided better intubating conditions with or without opioid use. The subgroup of trials using a narcotic in the sequence favoured the succinylcholine group (RR 0.85, 95\% Cl 0.78 to 0.93 ; participants $=2292$; studies $=34 ; 1^{2}$ statistic $=74 \%$; Analysis 4.1). The NNTH for the subgroup using narcotics was seven $(95 \%$ $\mathrm{Cl} 10$ to 6). The subgroup without a narcotic in sequence also demonstrated a statistically significant difference (RR $0.85,95 \% \mathrm{Cl}$ 0.76 to 0.95 ; participants $=1428$; studies $=16 ;\left.\right|^{2}$ statistic $=76 \%$; Analysis 5.1). The NNTH for this subgroup was six (95\% $\mathrm{Cl} 9$ to 5). There was significant heterogeneity present for both groups.

\section{Subgroup analysis for the primary outcome of excellent intubation conditions: age groups}

The paediatric subgroup demonstrated no statistically significant difference between rocuronium and succinylcholine (RR 0.86, 95\% $\mathrm{Cl} 0.70$ to 1.06 ; participants $=536$; studies $=5 ; 1^{2}$ statistic $=81 \%$ ). There was significant heterogeneity between the five paediatric trials (Figure 6).

\section{Subgroup analysis for the primary outcome of excellent intubation conditions: emergency intubation}

For the subgroup comparing rocuronium and succinylcholine in emergency participants, there was a statistically significant RR favouring succinylcholine (RR $0.84,95 \% \mathrm{Cl} 0.73$ to 0.98 ; participants $=1073$; studies $=5 ;\left.\right|^{2}$ statistic $=53 \%$; Analysis 7.1). The NNTH was $12(95 \% \mathrm{Cl} 38$ to 7$)$ for this subgroup, and there was no significant heterogeneity between trials.

\section{Inter-observer agreement}

In the first version of this review (Perry 2003), there was complete agreement between both evaluators regarding article selection (Kappa statistics 1.0). For this most recent update, the Kappa statistic was 0.9 for the articles.

\section{DISCUSSION}

\section{Summary of main results}

\section{Primary and secondary outcomes}

This review summarizes the results of 50 trials in 41521 participants, demonstrating moderate-quality evidence that succinylcholine creates better intubation conditions than rocuronium for both excellent and clinically acceptable intubation conditions during a rapid sequence induction. This is the same conclusion that we drew in our previous update (Perry 2008). The number of failed intubations was very small, with no clinically or statistically significant difference between rocuronium and succinylcholine.

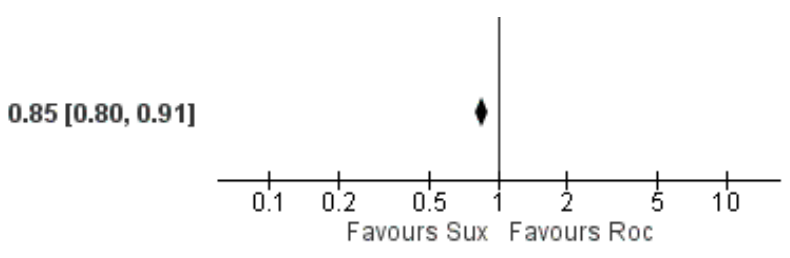

\section{Subgroup analysis}

We have demonstrated that succinylcholine is superior to rocuronium when either a simulated or modified RSI technique is used. There are now two trials $(n=148)$ with mixed simulated RSI and modified RSI demonstrating no difference between the two muscle relaxants.

An interesting finding in this current update is the conclusion regarding an induction agent used with the muscle relaxant. Thiopental was found to provide superior intubating conditions with or without the use of a narcotic. This is contrary to the conclusions of the last update (Perry 2008). This switch in induction agent of choice was the result of the addition of six trials which used thiopental in this update, representing a total of 800 participants (Abu-Halaweh 2007; Ali 2008; Iqbal 2013; Kulkarni 2010; Mencke 2005; Tripathi 2010). Unfortunately, this finding will have limited clinical applicability in North America, where the availability of thiopental has become very limited. When propofol was used as an induction agent, we found no significant difference between the two muscle relaxants with or without narcotics. The failure of narcotics to make a difference to the quality of intubation conditions is contrary to research which has reported significantly improved intubation conditions with the addition of a narcotic to the induction sequence (Sparr 1996b). This suggests that narcotics can safely be omitted in patients for whom they are contraindicated.

The dose of rocuronium has been thought to be important in creating intubation conditions equivalent to succinylcholine. This meta-analysis did not find conclusive evidence that increasing doses of rocuronium led to better intubating conditions. Succinylcholine created significantly more excellent intubation conditions than rocuronium at doses of 0.6 to $0.7 \mathrm{mg} / \mathrm{kg}$. There was no statistically significant difference for the 0.9 to $1.0 \mathrm{mg} /$ $\mathrm{kg}$ or $1.2 \mathrm{mg} / \mathrm{kg}$ groups, reaffirming the dose of rocuronium used in current practice for RSI when succinylcholine is not clinically indicated. It is difficult to draw conclusions regarding the higher doses of rocuronium, as there are relatively few studies which have examined the higher dose $(1.2 \mathrm{mg} / \mathrm{kg}$ ) of rocuronium ( $\mathrm{n}$ $=86$ ). It is possible that there may be a benefit to using an increased dose of rocuronium but this meta-analysis does not support this from the studies conducted to date. However, it should be noted that rocuronium has a longer duration of action compared to succinylcholine, and that increasing the dose of rocuronium increases its duration of action (73 \pm 32 minutes for $1.2 \mathrm{mg} / \mathrm{kg}$ dose, Magorian 1993) which can result in an increased incidence of adverse outcomes (i.e. increased duration of paralysis in a patient who cannot be successfully intubated).

We include a subgroup analysis for participants undergoing emergency intubation from the last updated version of the 
review (Perry 2008). We have demonstrated that succinylcholine is superior to rocuronium in creating excellent intubation conditions. This is consistent with our findings in the less than 60-second time delay subgroup. There was, however, no significant difference between groups for the outcome of clinically acceptable intubation, indicating that in emergency patients for whom succinylcholine is contraindicated, rocuronium can still be used to reliably create acceptable intubating conditions.

The five paediatric trials (Cheng 2002; Kulkarni 2010; Mazurek 1998; Naguib 1997; Stoddart 1998) did not demonstrate a difference in creating excellent intubation conditions between the rocuronium and succinylcholine groups. However, these had very little power to demonstrate any statistically significant difference due to the small sample size (i.e. underpowered for an equivalence trial). In addition, two of the trials (Naguib 1997; Stoddart 1998) used propofol in the sequence, while a third (Mazurek 1998) used a high dose of rocuronium $(1.2 \mathrm{mg} / \mathrm{kg}$ ) which may have confounded the results. This update includes a trial where ketamine was used in addition to a benzodiazepine as a premedication for particularly young children, further confounding the comparison (Kulkarni 2010).

\section{Overall completeness and applicability of evidence}

Although the search parameters were designed to identify any articles that could be pertinent to our research question, it is still possible that we have missed research not included in the databases accessible to the English-speaking community. The inclusion of non-English articles necessitated translation which, if performed poorly, could be a source of error, especially when assessing the specific domains of risk of bias. For the majority of cases, we pooled data presented in the publications for metaanalysis. We obtained data from one trial (Sluga 2005) through correspondence with the authors.

This review has identified trials involving participants from a wide age range (one to 77 years) in a variety of clinical settings, including both elective and emergency intubations in the operating room, emergency department and intensive care unit. The funnel plot of the included trials indicates a lack of trials in the right lower quadrant which may represent small unpublished trials favouring the use of rocuronium (Figure 4). However, the reason for such trials not being reported is not evident. Another reason for the asymmetric funnel plot is heterogeneous study effects that can be seen with varying study sizes, intubation sequences and study populations. More effective intubation conditions can be achieved with larger doses of rocuronium, with the drawback of prolonging muscle paralysis and length of intubation. This adverse outcome was not reported in the included trials, although there is a report of tachycardia and coughing. This review is unable to draw conclusions regarding safety.

\section{Quality of the evidence}

We found a significant amount of heterogeneity in the analysis of the primary outcome, which we tried to explore with subgroup analyses separating by age, emergencies, doses of rocuronium, timing of muscle relaxant, induction agent and opioid use. The $\mathrm{I}^{2}$ statistical value never fell below the $50 \%$ thresholds with these sensitivity analyses, nor did the direction or size of the summary estimate. As a result, we did not downgrade the quality of evidence, because unexplored reasons for heterogeneity include:
1. Different populations (varying from simple elective limb surgery to more complex gastric bypass on morbidly obese patients and emergent intensive care intubations);

2. Varying clinical settings;

3. Different medications in induction sequences;

4. Different timing of intubation.

All of these contribute to the generalizability of our results and to reducing concerns about indirectness.

Assessments of the risk of biases demonstrate that the series of trials included in this review are at low risk of selection and attrition bias . All but one trial was described as a randomized controlled trial, with $11 \%$ of trials being at high risk for lack of allocation concealment. The area of most concern was the high incidence of detection bias due to lack of blinding of the outcome assessor, which led to a downgrading of the quality of evidence to moderate. Succinylcholine will cause significant fasciculations, and intubators who are not blinded to this effect may assign biased scores to the intubating conditions. We conducted a subgroup analysis based on the blinding of the outcome assessor which failed to explain the source of the heterogeneity in the meta-analysis (Analysis 8.1). There were no concerns regarding the precision of the estimate, with more than 4000 participants included in the pooled estimate.

\section{Potential biases in the review process}

Because the original review was published in 2003 (Perry 2003), this update had to retrospectively formulate 'Risk of bias' tables, a 'Summary of findings' table and GRADE the quality of evidence in accordance with updated Cochrane guidelines. This process may have led to loss of details, now regarded as pertinent, involving inclusions/exclusion decisions made in the previous updates.

With the large number of possible sequences used, multiple testing can result in erroneous conclusions just by chance. This effect was minimized with the use of sensitivity analysis in prespecified subgroups. We conducted an additional subgroup analysis post hoc based on detection bias, to try and account for the heterogeneity observed in the results. At the time of inception of this review, doses of $0.6 \mathrm{mg} / \mathrm{kg}$ of rocuronium were being given for RSI, but higher doses of $1 \mathrm{mg} / \mathrm{kg}$ are now favoured, and the subgroup analyses allowed for assessment of these different doses.

\section{Agreements and disagreements with other studies or reviews}

A retrospective review of $327 \mathrm{RSI}$ intubations using etomidate with rocuronium or succinylcholine in the emergency department showed equivalent success at first intubation attempts (Patanwala 2011). Median doses for rocuronium were $1.19 \mathrm{mg} / \mathrm{kg}$ and $1.5 \mathrm{mg} / \mathrm{kg}$ of succinylcholine. Herbstritt 2012 is a short review looking at use of equivalent doses of rocuronium and succinylcholine $(1 \mathrm{mg} / \mathrm{kg})$ for RSI. They included seven papers of varying quality (retrospective review, RCT and meta-analysis), and concluded that there are no differences in intubating conditions between the two. This is consistent with our finding in the 0.9 to $1.0 \mathrm{mg} / \mathrm{kg}$ dose range (RR $0.95,95 \% \mathrm{Cl} 0.89$ to 1.00 ; participants $=1458$; studies $=16 ; 12$ statistic $=44 \%)$. When using doses of $0.6 \mathrm{mg} / \mathrm{kg}$ of rocuronium, Larsen 2005 used alfentanil and propofol as their induction agents and found no difference between rocuronium and succinylcholine $1 \mathrm{mg} / \mathrm{kg}$ in achieving clinically acceptable intubating conditions. These results are also consistent with those reported in this review for the 
secondary outcome (RR 0.99, 95\% $\mathrm{Cl} 0.96$ to 1.02 ; participants = 952; studies $=16 ; 1^{2}$ statistic $\left.=19 \%\right)$.

\section{AUTHORS' CONCLUSIONS}

\section{Implications for practice}

There is moderate-quality evidence to show that succinylcholine creates excellent intubation conditions more reliably than rocuronium and should still be used as a first-line muscle relaxant for rapid sequence induction endotracheal intubations. If an alternative agent is required, rocuronium $1 \mathrm{mg} / \mathrm{kg}$ can be used to create acceptable intubation conditions but should only be used as a second-line treatment because the length of paralysis will be significantly prolonged. The introduction of suggamadex to facilitate reversal of non-depolarizing muscle relaxants may decrease the incidence of this complication, but this drug is not currently widely available (Soto 2015).

\section{Implications for research}

Any further trials comparing succinylcholine should make certain to blind the outcome assessor to the obvious fasciculations triggered by succinylcholine. Most of the included trials assessed intubation conditions using the variables: ease of laryngoscopy, vocal cord motion and diaphragm movement. These measures should be maintained to allow for consistent comparison between trials. Although there are now five trials (Larsen 2005; Marsch 2011; Mazurek 1998; McCourt 1998; McCourt 1998) involving emergency participants, further trials in this patient population may reveal differences in results because etomidate is more often used as an induction agent than in the operating room. There was a lack of reporting of adverse outcomes in the trials, which should be remedied in any trials performed in the future.

\section{ACKNOWLEDGEMENTS}

We would like to thank: Andrew Smith (content editor), Cathal Walsh (statistical editor), and Mary Meyers (consumer referee) for their help and editorial advice during the preparation of this updated systematic review.

We would also like to thank:

Mrs Jessie McGowen who helped generate the initial search strategy.

Dr Gina Neto who assessed foreign language articles.

Mrs Beverly Shea who assisted with methodology of conducting the meta-analysis.

Mrs Verda Toprak who assessed foreign language articles. Dr Altan Sahin who assessed foreign language articles. 
REFE RE N CES

\section{References to studies included in this review}

\section{Abdulatif 1996 \{published data only\}}

Abdulatif M, al-Ghamdi A, el-Sanabary M. Rocuronium priming of atracurium-induced neuromuscular blockade: the use of short priming intervals. Journal of Clinical Anesthesia 1996;8(5):376-81. [MEDLINE: 8832448]

\section{Abu-Halaweh 2007 \{published data only\}}

Abu-Halaweh SA, Massad IM, Abu-Ali HM, Badran IZ, Barazangi BA, Ramsay MA. Rapid sequence induction and intubation with $1 \mathrm{mg} / \mathrm{kg}$ rocuronium bromide in cesarean section, comparison with suxamethonium. Saudi Medical Journal 2007;28(9):1393-6. [CENTRAL: CN-00619147]

\section{Alanoglu 2006 \{published data only\}}

Alanoglu Z, Ates Y, Yilmaz AA, Tuzuner F. Is there an ideal approach for rapid-sequence induction in hypertensive patients?. Journal of Clinical Anesthesia 2006;18(1):34-40. [MEDLINE: 16517330]

\section{Ali 2008 \{published data only\}}

Ali J, Gurckoo SA, Shora A, Qazi S. Intubating conditions of rocuronium bromide and succinylcholine during rapid sequence induction of anaesthesia in unpremedicated adult patients. Journal of Anaesthesiology Clinical Pharmacology 2008;24(3):337-42. [CENTRAL: CN-00708388]

\section{Alvarez Rios1997 \{published data only\}}

Alvarez Rios JJ, Hernandez MV, Baez L, Meza G, Higuera E, Gomez B. Analysis of the effects of rocuronium, mivacurium and succinylcholine for endotracheal intubation. [Analisis del comportamiento de rocuronio, mivacurio y succinilcolina en la intubacion endotraqueal]. Revista Mexicana De Anestesiologia 1997;20:122-6. [EMBASE: 1997330912]

\section{Andrews 1999 \{published data only\}}

Andrews JI, Kumar N, Van den Brom RH, Olkkola KT, Roest GJ, Wright PM. A large simple randomized trial of rocuronium versus succinylcholine in rapid-sequence induction of anaesthesia along with propofol. Acta Anaesthesiologica Scandinavica 1999;43(1):4-8. [PUBMED: 9926179]

\section{Belyamani 2008 \{published data only\}}

Belyamani L, Azendour A, Elhassouni A, Zidouh S, Atmani M, Kamili. Effect of ephedrine on the intubation conditions using rocuronium versus succinylcholine [Effet de l'éphédrine sur les conditions d'intubation après bloc neuromusculaire par le rocuronium versus succinylcholine]. Annales Français d'Anesthésie et de Réanimation 2008;27:292-6.

\section{Cheng 2002 \{published data only\}}

Cheung CA, Aun CS, Gin T. Comparison of rocuronium and suxamethonium for rapid tracheal intubation in children. Paediatric Anaaesthesia 2002;12(2):140-5. [MEDLINE: 11882225]

\section{Chiu 1999 \{published data only\}}

Chiu CL, Jaais F, Wang CY. Effect of rocuronium compared with succinylcholine on intraocular pressure during rapid sequence induction of anaesthesia. British Journal of Anaesthesia 1999;82(5):757-60. [MEDLINE: 10536557]

\section{Chung 2001 \{published data only\}}

Chung YT, Yeh LT. Effectiveness and safety of rocuroniumhypnotic sequence for rapid-sequence induction. Acta Anaesthesiologica Sinica 2001;39(1):3-9. [MEDLINE: 11407293]

\section{Cooper 1992 \{published data only\}}

* Cooper R, Mirakhur RK, Clarke RS, Boules Z. Comparison of intubating conditions after administration of org 9426 (rocuronium) and suxamethonium. British Journal of Anaesthesia 1992;69(3):269-73. [MEDLINE: 1389845]

Mirakhur RK, Cooper AR, Clarke RS. Onset and intubating conditions of rocuronium bromide compared to those of suxamethonium. European Journal of Anesthesiology 1994;11(Suppl. 9):41-3. [EMBASE: 1994232031]

\section{De Almeida 2009 \{published data only\}}

De Almeida MC, Pederneiras SG, Chiaroni S, De Souza L, Locks GF. Evaluation of tracheal intubation conditions in morbidly obese patients: a comparison of succinylcholine and rocuronium [Evaluación de las condiciones de intubación traqueal en pacientes obesos mórbidos: succinilcolina frente a rocuronio]. Revista Española de Anestesiología y Reanimación 2009;56(1):3-8. [CENTRAL: CN-00681643]

Dubois 1995 \{published data only\}

* Dubois M, Lea D, Kataria B, Gadde P, Tran D, Shearrow T. Pharmacodynamics of rocuronium with and without prior administration of succinylcholine. Journal of Clinical Anesthesia 1995;7(1):44-8. [MEDLINE: 7772357]

Dubois MY, Dubois MY, Shearrow T, Tran D, Kataria B, Rever L, Gadde LR. Org 9426 used for endotracheal intubation: a comparison with succinylcholine. Anesthesiology 1991;75(3A):A1066.

\section{Giudice 1998 \{published data only\}}

* Giudice G, Tomassini G, Baggianini A, Sagredini R. Speed and ease of endotracheal intubation with the neuromuscular monitoring guide (TOF) after rocuronium doses of various multiples of ED95 and succinylcholine [Tempi e qualita dell'intubazione sulla guida del monitoraggio neuromuscolare (TOF): confronto tra vari multipli della ED95 del rocuronio e succinilcolina]. Acta Anaesthesiologica Italica 1998;49(3):231-9. [EMBASE: 1999095079]

\section{Iqbal 2013 \{published data only\}}

Iqbal M, Turab SM, Siddiqui MH, Jawad-Us-Salam, Majid U, Ali Baloch A, et al. To compare the efficacy of rocuronium bromide and succinylcholine in elective surgery for endotracheal tube. Medical Forum (Monthly) 2013;24(7):38-41. [EMBASE: 2013630011]

\section{Koroglu 2002 \{published data only\}}

Koroglu N, Iyilikci L, Van Koroglu L, Atay A, Gokel E. Comparison of rocuronium and succinylcholine for rapid sequence intubation cesarean section [Sezaryen Olgularinda Hizli 
Endotrokeal Entubasyonda Rokuronyum ve Suksiniklolinin Karsilastmlmasi]. Turk Anesteziyoloji Ve Reanimasyon Cemiyeti Mecmuasi 2002;30:173-80. [EMBASE: 2002280227]

\section{Kulkarni 2010 \{published data only\}}

Kulkarni K, Patil M, Shirke A. Comparison of intubating conditions of succinylcholine with two doses of rocuronium bromide in children. Journal of Anaesthia Clinical Pharmacology 2010;26(3):323-8. [EMBASE: 2010533834]

Kwon 2013 \{published data only\}

Kwon MA, Song J, Kim J-R. Tracheal intubation with rocuronium using a "modified timing principle". Korean Journal of Anesthesiology 2013;64(3):218-22. [EMBASE: 2013214600]

\section{Lam 2000 \{published data only\}}

Lam AM, Pavlin EG, Visco E, Taraday J. Rocuronium versus succinylcholine-atracurium for tracheal Intubation and maintenance relaxation during propofol anesthesia. Jounal of Clinical Anesthesia 2000;12(6):449-53. [MEDLINE: 11090730]

\section{Larsen 2005 \{published data only\}}

Larsen PB, Hansen EG, Jocobsen LS, Wiis J, Holst P, Rottensten $\mathrm{H}$, et al. Intubation conditions after rocuronium or succinylcholine for rapid sequence induction with alfentanil and propofol in the emergency patient. European Journal of Anesthesiology 2005;22(10):748-53. [MEDLINE: 16211732]

\section{Latorre 1996 \{published data only\}}

Latorre F, Stanek A, Gervais HW, Kleemann PP. Intubation requirements after rocuronium and succinylcholine [Intubations bedingungen nach rocuronium und succinylcholin]. Anästhesiologie, Intensivmedizin, Notfallmedizin, Schmerztherapie: AINS 1996;31(8):470-3. [MEDLINE: 9019175]

\section{Le Corre 1999 \{published data only\}}

Le Corre F, Plaud B, Benhamou E, Debaene B. Visual estimation of onset time at the orbicularis oculi after five muscle relaxants: application to clinical monitoring of tracheal intubation. Anesthesia and Analgesia 1999;89(5):1305-10. [MEDLINE: 10553857]

\section{Magorian 1993 \{published data only\}}

Magorian T, Flannery KB, Miller RD. Comparison of rocuronium, succinylcholine, and vecuronium for rapid-sequence induction of anesthesia in adult patients. Anesthesiology 1993;79(5):913-8. [MEDLINE: 7902034]

\section{Malik 2004 \{published data only\}}

Malik P, Rao S, Malhotra N, Chugh JP, Hooda S. Comparative evaluation of effect of rocuronium and succinylcholine on intraocular pressure. Journal of Anaesthesia and Clinical Pharmacology 2004;20(3):255-61. [EMBASE: 2005146384]

\section{Marsch 2011 \{published data only\}}

Marsch SC, Steiner L, Bucher E, Pargger H, Schumann M, Aebi T, et al. Succinylcholine versus rocuronium for rapid sequence intubation in intensive care: A prospective, randomized controlled trial. Critical Care 2011;15(4):R199. [PUBMED: 21846380]
Mazurek 1998 \{published data only\}

Mazurek AJ, Rae B, Hann S, Kim JI, Castro B, Cote CJ. Rocuronium versus succinylcholine: are they equally effective during rapid-sequence induction of anesthesia?. Anesthesia and Analgesia 1998;87(6):1259-62. [MEDLINE: 9842809]

McCourt 1998 \{published data only\}

McCourt KC, Salmela L, Mirakhur RK, Carroll M, Makinen MT, Kansansho M, et al. Comparison of rocuronium and suxamethonium for use during rapid sequence induction of anaesthesia. Anaesthesia 1998;53(9):867-71. [MEDLINE: 9849280]

Mencke 2005 \{published data only\}

Mencke T, Scherelber J-U, Knoll H, Werth M, Grundmann U, Rensing $\mathrm{H}$. Influence of gender on the intubation conditions with rocuronium [Ein fluss des Ges chlechts auf die Int ub at io nsb ed ing ung en nach Ro cu ro ni um]. Der Anaesthesist 2005;54:884-8.

\section{Mencke 2006 \{published data only\}}

Mencke T, Knoll H, Schreiber JU, Echternach M, Klein S, Noeldge-Schomburg G, et al. Rocuronium is not associated with more vocal cord injuries that succinylcholine after rapidsequence induction: a randomized, prospective, controlled trial. Anesthesia and Analgesia 2006;102(3):943-9. [MEDLINE: 16492856]

\section{Mitra 2001 \{published data only\}}

Mitra S, Gombar KK, Gombar S. The effect of rocuronium on intraocular pressure: a comparison wiht succinylcholine. European Journal of Anaesthesiology 2001;18(12):836-8. [MEDLINE: 11737185]

\section{Naguib 1994 \{published data only\}}

Naguib M. Different priming techniques, including mivacurium, accelerate the onset of rocuronium. Canadian Journal of Anaesthesia 1994;41(10):902-7. [MEDLINE: 8001208]

\section{Naguib 1997 \{published data only\}}

Naguib M, Samarkandi AH, Ammar A, Turkistani A. Comparison of suxamethonium and different combinations of rocuronium and mivacurium for rapid tracheal intubation in children. British Journal of Anaesthesia 1997;79(4):450-5. [PUBMED: 389261 ]

\section{Nelson 1997 \{published data only\}}

Nelson JM, Morell RC, Butterworth JF 4th. Rocuronium versus succinylcholine for rapid-sequence induction using a variation of the timing principle. Journal of Clinical Anesthesia 1997;9(4):317-20. [MEDLINE: 9195356]

Patel 1995 \{published data only\}

Patel N, Smith CE, Pinchak AC. Emergency surgery and rapid sequence intubation: rocuronium vs succinylcholine. Anesthesiology 1995;83(3A):A914.

Pühringer 1992 \{published data only\}

Pühringer FK, Khuenl-Brady KS, Koller J, Mitterschiffthaler G. Evaluation of the endotracheal intubating conditions of rocuronium (org 9426) and succinylcholine in outpatient 
surgery. Anesthesia and Analgesia 1992;75(1):37-40. [MEDLINE: 1616158]

\section{Singh 2011 \{published data only\}}

Ratan Singh N, Thangluai T, Laithangbam PKS, Hemjit Singh T, Chaoba Singh L, Shanti Devi RK. Comparison of intubating conditions of succinylcholine, vecuronium and rocuronium in patients undergoing elective surgery - a study. Journal of Medical Society 2011;25(2):54-8. [EMBASE: 2013558709]

\section{Sluga 2005 \{published data only\}}

Sluga M, Ummenhofer W, Studer W, Siegemund M, Marsch SC. Rocuronium versus succinylcholine for rapid sequence induction of anesthesia and endotracheal intubation: A prospective, randomized trial in emergent cases. Anesthesia and Analgesia 2005;101(5):1356-61. [MEDLINE: 16243994]

\section{Sorensen 2012 \{published data only\}}

Sorensen MK, Bretlau C, Gatke MR, Sorensen AM, Rasmussen LS. Rapid sequence induction and intubation with rocuroniumsugammadex compared with succinylcholine: a randomized trial. British Journal of Anaesthesia 2012;108(4):682-9. [PUBMED: 22315329]

\section{Sparr 1996a \{published data only\}}

Sparr HJ, Luger TJ, Heidegger T, Putensen-Himmer G. Comparison of intubating conditions after rocuronium and suxamethonium following "rapid-sequence induction" with thiopentone in elective cases. Acta Anaesthesiologica Scandinavica 1996;40(4):425-30. [MEDLINE: 8738686]

\section{Sparr 1996b \{published data only\}}

Sparr HJ, Giesinger S, Ulmer H, Hollenstein-Zache M, Luger TJ. Influence of induction technique on intubating conditions after rocuronium in adults: comparison with rapid-sequence induction using thiopentone and suxamethonium. British Journal of Anaesthesia 1996;77(3):339-42. [MEDLINE: 8949806]

\section{Stevens 1996 \{published data only\}}

Stevens JB, Shepherd JM, Vories PA, Walker SC, Vescovo MV. A mixture of mivacurinum and rocuronium is comparable in clinical onset to succinylcholine. Journal of Clinical Anesthesia 1996;8(6):486-90. [MEDLINE: 8872689]

\section{Stoddart 1998 \{published data only\}}

Stoddart PA, Mather SJ. Onset of neuromuscular blockade and intubating conditions one minute after the administration of rocuronium in children. Paediatric Anaesthesia 1998;8(1):37-40. [MEDLINE: 9483596]

\section{Tang 1996 \{published data only\}}

Tang J, Joshi GP, White PF. Comparison of rocuronium and mivacurium to succinylcholine during outpatient laparoscopic surgery. Anesthesia and Analgesia 1996;82(5):994-8. [MEDLINE: 8610912]

\section{Tripathi 2010 \{published data only\}}

Tripathi D, Trivedi L, Doshi S, Shah C, Sheth P. Evaluation of onset of action and endotracheal intubating conditions after suxamethonium chloride and rocuronium bromide in adults. Journal of Anaesthesiology Clinical Pharmacology 2010;26(3):350-4. [EMBASE: 2010533839]

Tryba 1994 \{published data only\}

Tryba M, Zorn A, Thole H, Zenz, M. Rapid-sequence orotracheal intubation with rocuronium: a randomized double-blind comparison with suxamethonium-preliminary communication. European Journal of Anaesthesiology 1994;11(suppl. 9):44-8. [MEDLINE: 7925207]

Turan 1999 \{published data only\}

Turan G, Ozgultekin A, Bafali M, Kasikci M, Senel NA. Is rocuronium an alternative to succinylcholine?. Türk Anesteziyoloji ve Reanimasyon Derne 1999;27(4):193-7. [EMBASE: 1999190725]

\section{Türkmen 2004 \{published data only\}}

Türkmen A, Altan A, Turgut N, Uluç A, Kutlu F, Üstün H, Kamalı S. Mivacurium in balanced anesthesia, intubation with succinylcholine rocuronium and conditions and clinical effects comparison of time [Dengeli Anestezide Mivakuryumun, Rokuronyum ve Süksinilkolin İle Entübasyon Koşulları ve Klinik Etki Süresi Açısından Karşılaştırılması]. Türk Anesteziyoloji ve Reanimasyon 2004;322:85-90.

\section{Vinik 1999 \{published data only\}}

Vinik HR. Intraocular pressure changes during rapid sequence induction and intubation: a comparison of rocuronium, atracurium and succinylcholine. Journal of Clinical Anesthesia 1999;11(2):95-100. [MEDLINE: 10386278]

\section{Weiss 1997 \{published data only\}}

Weiss JH, Gratz I, Goldberg ME, Afshar M, Insinga F, Larijani G. Double-blind comparison of two doses of rocuronium and succinylcholine for rapid-sequence intubation. Journal of Clinical Anesthesia 1997;9(5):379-82. [MEDLINE: 9257203]

\section{Yorukoglu 2003 \{published data only\}}

Yorukoglu D, Asik Y, Okten F. Rocuronium combined with i.v. lidocaine for rapid tracheal intubation. Acta Anaesthesiologica Scandinavica 2003;47(5):583-7. [MEDLINE: 12699517]

\section{References to studies excluded from this review}

Dobson 1999 \{published data only\}

Dobson AP, McCluskey A, Meakin G, Baker RD. Effective time to satisfactory intubation conditions after administration of rocuronium in adults. Comparison of propofol and thiopentone for rapid sequence induction of anaesthesia. Anaesthesia 1999;54(2):172-6. [MEDLINE: 10215713]

Dubois 1992 \{published data only\}

Dubois MY, Lapeyre G, Lea D, Tran DQ, Kateria BK. Pharmacodynamic effects of three doses of ORG 9426 used for endotracheal intubation in humans. Journal of Clinical Anesthesia 1992;4(6):472-5. [MEDLINE: 1457115]

\section{Hemmerling 2000 \{published data only\}}

Hemmerling TM, Schmidt J, Wolf T, Klein P, Jacobi K. Comparison of succinylcholine with two doses of rocuronium using a new method of monitoring neuromuscular block at 
the laryngeal muscles by surface laryngeal electromyography. British Journal of Anaesthesia 2000;85(2):251-5. [PUBMED: 10992834 ]

\section{Huizinga 1992 \{published data only\}}

Huizinga AC, Vandenbrom RH, Wierda JM, Hommes FD, Hennis PJ. Intubating conditions and onset of neuromuscular block of rocuronium (org 9426); a comparison with suxamethonium. Acta Anaesthesiologica Scandinavica 1992;36(5):463-8. [MEDLINE: 1321542]

Lam 1997 \{published data only\}

Lam AM, Pavlin EG. Rocuronium versus succinylcholineatracurium for tracheal intubation and maintenance relaxation. European Journal of Anaesthesiology 1997;14(Suppl. 16):13. [CENTRAL: CN-00330684]

\section{Martin 1998 \{published data only\}}

Martin R, Carrier J, Pirlet M, Claprood Y, Tetrault JP. Rocuronium is the best non-depolarizing relaxant to prevent succinylcholine fasciculations and myalgia. Canadian Journal of Anaesthesia 1998;45(6):521-5. [MEDLINE: 9669004]

Misiolek 2009 \{published data only\}

Misiolek H, Tombarkiewicz M, Zajaczkowska-Druzba K, Rutkowska K. Rocuronium vs atracurium vs suxamethonium for double-lumen endobronchial tube intubation. Anestezjologia Intensywna Terapia 2009;41(2):68-72. [CENTRAL: CN-00719576]

\section{Naguib 1994b \{published data only\}}

Naguib M. Neuromuscular effects of rocuronium bromide and mivacurium chloride administered alone and in combination. Anesthesiology 1994;81(2):388-95. [MEDLINE: 8053589]

\section{Ortiz-Gómez 2005 \{published data only\}}

Ortiz-Gómez JR, Carrascosa F, Pérez-Cajaraville JJ, PercazBados JA, Añez C. Comparative study of intubating conditions at the first minute with suxamethonium, rocuronium and different priming techniques of rocuronium. European Journal of Anesthesiology 2005;22(4):263-8. [MEDLINE: 15892403]

\section{Robertson 2004 \{published data only\}}

Robertson EN, Driessen JJ, Booij LH. Suxamethonium administration prolongs the duration of action of subsequent rocuronium. European Journal of Anaesthesiology 2004;21(9):734-7. [MEDLINE: 15595587]

\section{Stourac 2013 \{published data only\}}

Stourac P, Adamus M, Seidlova D, Krikava I, Kosinova M, Hejduk K. Use of rocuronium and active reversal of neuromuscular blockade with sugammedex does not shorten operating time during caesarean section in compare to suxamethonium, rocuronium and negostigmine: prospective randomised interventional multicentre trial. European Journal of Anesthesiology 2013;Supplement 51:179-80.

\section{Vianna 1997 \{published data only\}}

Vianna PT, Castiglia YM, Ganem EM, Takata IH, Braz JR, Curi PR. Onset time and intubating conditions of rocuronium and succinylcholine. Revista Brasileira de Anestesiologia 1997;47(5):401-7. [EMBASE: 1997304088]
Vincent 1996 \{published data only\}

Vincent MO, Schippers HC, De Lange JJ. Rocuronium versus succinylcholine versus vecuronium. Nederland Tijdschrift voor Aneshesiologie 1996;9:132. [CENTRAL: CN-00251009]

Woolf 1997 \{published data only\}

Woolf RL, Crawford MW, Choo SM. Dose-response of rocuronium bromide in children anesthetized with propofol a comparison with succinylcholine. Anesthesiology 1997;87(6):1368-72. [MEDLINE: 9416722]

\section{Additional references \\ Danzl 2000}

Danzl DF. Tracheal intubation and mechanical ventilation. In: Tintinalli JE, Kelen GD, Stapczynski JS editor(s). Emergency Medicine - A comprehensive study guide. Toronto: McGraw-Hill, 2000:85-96

\section{Goldberg 1989}

Goldberg ME, Larijani GE, Azad SS, Sosis M, Seltzer JL, Ascher J, et al. Comparison of tracheal intubating conditions and neuromuscular blocking profiles after intubating doses of mivacurium chloride or succinylcholine in surgical outpatients. Anesthesia and Analgesia 1989;69(1):93-9. [MEDLINE: 2525886]

\section{GRADEpro 2015 [Computer program]}

McMaster Univeristy. GRADEpro. Hamilton: McMaster Univeristy, 2015.

\section{Haynes 1994}

Haynes RB, Wilczynski N, McKibbon KA, Walker CJ, Sinclair JC. Developing optimal search strategies for detecting clinically sound studies in MEDLINE. Journal of the American Medical Informatics Association 1994;1(6):447-58. [MEDLINE: 7850570]

\section{Herbstritt 2012}

Herbstritt A, Amarakone K. Towards evidence-based emergency medicine: best BETs from the Manchester Royal Infirmary. BET 3: is rocuronium as effective as succinylcholine at facilitating laryngoscopy during rapid sequence intubation?. Emergency Medicine Journal 2012;29(3):256-8. [PUBMED: 22337834]

\section{Higgins 2003}

Higgins JPT, Thompson SG, Deeks JJ, Altman DG. Measuring inconsistency in meta-analyses [Measuring inconsistency in meta-analyses]. British Medical Journal 2003;327:557-560.

\section{Lebowitz 1989}

Lebowitz PW, Ramsey FM. Muscle relaxants. Clinical Anesthesia 1989;1:344-6.

\section{Martyn 2006}

Martyn JA, Richtsfel M. Succinylcholine-induced hyperkalemia in acquired pathologic states: etiologic factors and molecular mechanisms. Anesthesiology 2006;104(1):158-69. [PUBMED: 16394702] 


\section{Minton 1986}

Minton MD, Grosslight K, Stirt JA, Bedford RF. Increases in intracranial pressure from succinylcholine: prevention by prior nondepolarizing blockade. Anesthesiology 1986;65(2):165-9.

\section{Patanwala 2011}

Patanwala AE, Stahle SA, Erstad BL. Comparison of succinylcholine and rocuronium for first-attempt intubation success in the emergency department. Academic Emergency Medicine 2011;18(1):10-4. [PUBMED: 21182564]

\section{RevMan 5.3 [Computer program]}

The Cochrane Collaboration. Review Manager (RevMan). Version 5.3. Copenhagen: The Nordic Cochrane Centre: The Cochrane Collaboration, 2014.

\section{Schreiber 2005}

Schreiber JU, Lysakowski C, Fuchs-Buder T, Tramer MR. Prevention of succinylcholine-induced fasciculation and myalgia: a meta-analysis of randomized trials. Anesthesiology 2005;103(4):877-84. [PUBMED: 16192781]

\section{Soto 2015}

Soto R, Jahr JS, Pavlin J, Sabo D, Philip BK, Egan TD, et al. Safety and efficacy of rocuronium with sugammadex reversal versus succinylcholine in outpatient surgery - a multicenter, randomized, saftey assessor-blnded trial. American Journal of Therapeutics 2015;NA:epub ahead of print.

\section{Stollings 2014}

Stollings JL, Diedrich DA, Oyen LJ, Brown DR. Rapid sequence intubation: A review of the process and considerations

\section{CHARACTERISTICS OF STUDIES}

Characteristics of included studies [ordered by study ID] when choosing medications. Annals of Pharmacotherapy 2014;48(1):62-76.

\section{Sullivan 1994}

Sullivan M, Thompson WK, Hill GS. Succinylcholine induced cardiac arrest in children with undiagnosed myopathy. Canadian Journal of Anaesthesia 1994;41(6):497-501. [MEDLINE: 8069990]

\section{References to other published versions of this review Perry 2002}

Perry JJ, Lee J, Wells G. Are intubation conditions using rocuronium equivalent to those using succinylcholine? Academic Emergency Medicine 2002;9(8):813-32.

\section{Perry 2003}

Perry J, Lee J, Wells G. Rocuronium versus succinylcholine for rapid sequence induction intubation. Cochrane Database of Systematic Reviews 2003, Issue 1. [DOI: 10.1002/14651858.CD002788]

\section{Perry 2008}

Perry JJ, Lee JS, Silberg VAH, Wells GA. Rocuronium versus succinylcholine for rapid sequence induction intubation. Cochrane Database of Systematic Reviews 2008, Issue 2. [DOI: 10.1002/14651858.CD002788.pub2]

* Indicates the major publication for the study

Abdulatif 1996

\begin{tabular}{ll}
\hline Methods & RCT \\
& Mixed simulated and modified RSI \\
& $\mathrm{N}=144$
\end{tabular}


Abdulatif 1996 (Continued)

\section{Adductor pollicis response to TOF stimulation}

\begin{tabular}{|c|c|c|}
\hline Adverse events & \multicolumn{2}{|l|}{ None reported } \\
\hline Time \& Place & \multicolumn{2}{|c|}{ Study dates not reported. Article accepted November 1995.} \\
\hline & \multicolumn{2}{|c|}{ King Fahad University Hospital, Al-Khobar, Saudi Arabia. } \\
\hline Funding and declarations & \multicolumn{2}{|c|}{ Funding source: none declared } \\
\hline & \multicolumn{2}{|c|}{ Declarations of interest: none declared } \\
\hline Notes & \multicolumn{2}{|l|}{ Efficacy analysis } \\
\hline \multicolumn{3}{|l|}{ Risk of bias } \\
\hline Bias & Authors' judgement & Support for judgement \\
\hline $\begin{array}{l}\text { Random sequence genera- } \\
\text { tion (selection bias) }\end{array}$ & Low risk & Sealed envelopes \\
\hline $\begin{array}{l}\text { Allocation concealment } \\
\text { (selection bias) }\end{array}$ & Low risk & Participants were randomly allocated via closed envelope \\
\hline $\begin{array}{l}\text { Blinding of participants } \\
\text { and personnel (perfor- } \\
\text { mance bias) } \\
\text { All outcomes }\end{array}$ & Low risk & $\begin{array}{l}\text { Participant asleep and personnel performance does not affect intubating con- } \\
\text { ditions }\end{array}$ \\
\hline $\begin{array}{l}\text { Blinding of outcome as- } \\
\text { sessment (detection bias) } \\
\text { All outcomes }\end{array}$ & High risk & No mention of blinding \\
\hline $\begin{array}{l}\text { Incomplete outcome data } \\
\text { (attrition bias) } \\
\text { All outcomes }\end{array}$ & Low risk & Data for all participants reported \\
\hline $\begin{array}{l}\text { Selective reporting (re- } \\
\text { porting bias) }\end{array}$ & Low risk & All outcomes reported \\
\hline
\end{tabular}

\section{Abu-Halaweh 2007}

\begin{tabular}{ll}
\hline Methods & RCT \\
& Elective and emergency caesarean section \\
& $\mathrm{N}=120$ \\
\hline Participants & ASA I - II \\
Pregnant women & Mean age 32 \\
Mean weight $78 \mathrm{~kg}$
\end{tabular}

Interventions

1, Rocuronium $1 \mathrm{mg} / \mathrm{kg}(\mathrm{n}=60)$ 
Abu-Halaweh 2007 (Continued)

$$
\text { 2, Succinylcholine } 1 \mathrm{mg} / \mathrm{kg}(\mathrm{n}=60)
$$

Sequence with: thiopental $5 \mathrm{mg} / \mathrm{kg}$

\begin{tabular}{ll}
\hline Outcomes & $\begin{array}{l}\text { 1. Intubating conditions by senior anaesthetist } 60 \text { s after muscle relaxant. Reported as excellent, good } \\
\text { and poor, as modified Viby-Mogenson Grading system. Features included jaw relaxation, vocal cord po- } \\
\text { sition and diaphragmatic activity }\end{array}$
\end{tabular}

\begin{tabular}{ll}
\hline Adverse events & Slight increase in heart rate after 5 mins with rocuronium use. \\
\hline Time \& Place & December 2005 to May 2006 \\
& Jordan University Hospital, Jordan \\
\hline
\end{tabular}

Funding and declarations Funding source: none declared

Declarations of interest: none declared

\section{Notes}

\section{Risk of bias}

\begin{tabular}{|c|c|c|}
\hline Bias & Authors' judgement & Support for judgement \\
\hline $\begin{array}{l}\text { Random sequence genera- } \\
\text { tion (selection bias) }\end{array}$ & Low risk & Randomly shuffled envelopes, probably adequate \\
\hline $\begin{array}{l}\text { Allocation concealment } \\
\text { (selection bias) }\end{array}$ & Low risk & $\begin{array}{l}\text { Randomly shuffled sealed envelopes indicating the type of the muscle relaxant } \\
\text { to be used for intubation }\end{array}$ \\
\hline $\begin{array}{l}\text { Blinding of participants } \\
\text { and personnel (perfor- } \\
\text { mance bias) } \\
\text { All outcomes }\end{array}$ & Low risk & $\begin{array}{l}\text { Participant asleep and personnel performance does not affect intubating con- } \\
\text { ditions }\end{array}$ \\
\hline $\begin{array}{l}\text { Blinding of outcome as- } \\
\text { sessment (detection bias) } \\
\text { All outcomes }\end{array}$ & Low risk & $\begin{array}{l}\text { The intubator who was blinded to the type of administered muscle relaxant } \\
\text { was called to the theatre } 40 \text { s after the relaxant administration }\end{array}$ \\
\hline $\begin{array}{l}\text { Incomplete outcome data } \\
\text { (attrition bias) } \\
\text { All outcomes }\end{array}$ & Low risk & Data for all participants reported \\
\hline $\begin{array}{l}\text { Selective reporting (re- } \\
\text { porting bias) }\end{array}$ & Low risk & All outcomes reported \\
\hline
\end{tabular}

Alanoglu 2006

\begin{tabular}{ll}
\hline Methods & RCT \\
& $\begin{array}{l}\text { Modified RSI } \\
\mathrm{N}=119\end{array}$ \\
\hline Participants & $\begin{array}{l}\text { ASA II - III } \\
\text { Adult } \\
\text { Controlled hypertensive }\end{array}$ \\
\hline Interventions & 1. Succinylcholine $1.0 \mathrm{mg} / \mathrm{kg}$ with lidocaine $(\mathrm{n}=30)$
\end{tabular}


Alanoglu 2006 (Continued)

2. Rocuronium $1 \mathrm{mg} / \mathrm{kg}$ with lidocaine $(\mathrm{n}=30)$

3. Succinylcholine $1.0 \mathrm{mg} / \mathrm{kg}$ with remifentanil $(n=29)$

4. Rocuronium $1.0 \mathrm{mg} / \mathrm{kg}$ with remifentanil $(\mathrm{n}=30)$

Sequences with opiate (remifentanil) or no opiate and thiopental

Outcomes Intubating conditions 60 s after muscle relaxant. Reported as excellent, good, poor based on 6 vari-
ables (jaw relaxation, resistance to blade, vocal cord position and movement, movement of limbs and
coughing) with table of definitions
2. Haemodynamics before inductio, after induction and at intubation

\begin{tabular}{ll}
\hline Adverse events & Mild muscle rigidity in 6 participants with the use of remifentanil. \\
\hline Time \& Place & Study dates not reported. Article accepted June 2005 \\
& Ankara University, Ankara, Turkey \\
\hline Funding and declarations & Funding source: none declared \\
& Declarations of interest: none declared \\
\hline Notes & ITT analysis
\end{tabular}

\section{Risk of bias}

\begin{tabular}{|c|c|c|}
\hline Bias & Authors' judgement & Support for judgement \\
\hline $\begin{array}{l}\text { Random sequence genera- } \\
\text { tion (selection bias) }\end{array}$ & Low risk & Sealed envelope \\
\hline $\begin{array}{l}\text { Allocation concealment } \\
\text { (selection bias) }\end{array}$ & Low risk & Allocated to 4 groups at random by sealed envelope technique \\
\hline $\begin{array}{l}\text { Blinding of participants } \\
\text { and personnel (perfor- } \\
\text { mance bias) } \\
\text { All outcomes }\end{array}$ & Low risk & $\begin{array}{l}\text { Participant asleep and personnel performance does not affect intubating con- } \\
\text { ditions }\end{array}$ \\
\hline $\begin{array}{l}\text { Blinding of outcome as- } \\
\text { sessment (detection bias) } \\
\text { All outcomes }\end{array}$ & Unclear risk & $\begin{array}{l}\text { "Authors performing the intubation and scoring intubation conditions were } \\
\text { blinded to the study medications." Unclear if blinded allocation or drug ad- } \\
\text { ministration }\end{array}$ \\
\hline $\begin{array}{l}\text { Incomplete outcome data } \\
\text { (attrition bias) } \\
\text { All outcomes }\end{array}$ & Low risk & Adequately described in detail \\
\hline $\begin{array}{l}\text { Selective reporting (re- } \\
\text { porting bias) }\end{array}$ & Low risk & All outcomes reported \\
\hline
\end{tabular}

Ali 2008

\begin{tabular}{ll}
\hline Methods & RCT \\
& Mixed simulated and modified RSI \\
& $\mathrm{N}=100$ \\
\hline Participants & ASA I - II
\end{tabular}


Ali 2008 (Continued)

\section{Age 18 - 60 \\ Elective OR}

\begin{tabular}{ll}
\hline Interventions & 1. Rocuronium $0.6 \mathrm{mg} / \mathrm{kg}$ at $60 \mathrm{~s}(\mathrm{n}=25)$ \\
2. Rocuronium $0.6 \mathrm{mg} / \mathrm{kg}$ at $90 \mathrm{~s}(\mathrm{n}=25)$ \\
3. Succinylcholine $1.5 \mathrm{mg} / \mathrm{kg}$ at $60 \mathrm{~s}(\mathrm{n}=25)$ \\
4. Succinylcholine $1.5 \mathrm{mg} / \mathrm{kg}$ at $90 \mathrm{~s}(\mathrm{n}=25)$ \\
Sequence with thiopental $5 \mathrm{mg} / \mathrm{kg}$
\end{tabular}

Adverse events None reported

Time \& Place Study dates not reported. Article published 2008.

Sheri Kashmir Institute of Medical Sciences, Soura, Srinagar, India

\begin{tabular}{ll}
\hline Funding and declarations & $\begin{array}{l}\text { Funding source: none declared } \\
\text { Declarations of interest: none declared }\end{array}$
\end{tabular}

Notes Did not provide results of individuals groups. Used aggregate data, classified as modified RSI

\section{Risk of bias}

\begin{tabular}{|c|c|c|}
\hline Bias & Authors' judgement & Support for judgement \\
\hline $\begin{array}{l}\text { Random sequence genera- } \\
\text { tion (selection bias) }\end{array}$ & Unclear risk & "randomized" but did not elaborate \\
\hline $\begin{array}{l}\text { Allocation concealment } \\
\text { (selection bias) }\end{array}$ & Unclear risk & Used "double-blind" fashion \\
\hline $\begin{array}{l}\text { Blinding of participants } \\
\text { and personnel (perfor- } \\
\text { mance bias) } \\
\text { All outcomes }\end{array}$ & Low risk & $\begin{array}{l}\text { Participant asleep and personnel performance does not affect intubating con- } \\
\text { ditions }\end{array}$ \\
\hline $\begin{array}{l}\text { Blinding of outcome as- } \\
\text { sessment (detection bias) } \\
\text { All outcomes }\end{array}$ & Low risk & $\begin{array}{l}\text { Same fully-trained anaesthetist (Intubator) performed all the intubations, who } \\
\text { was called in the study room } 45 \mathrm{~s} \text { after the administration of the neuromus- } \\
\text { cular blocker in group A participants and after } 75 \mathrm{~s} \text { in group B participants (to } \\
\text { eliminate possible bias because of fasciculations induced by succinylcholine) } \\
\text { and intubation was attempted } 15 \mathrm{~s} \text { later }\end{array}$ \\
\hline $\begin{array}{l}\text { Incomplete outcome data } \\
\text { (attrition bias) } \\
\text { All outcomes }\end{array}$ & Unclear risk & Data were not presented for all 4 groups, aggregated into 2 groups \\
\hline $\begin{array}{l}\text { Selective reporting (re- } \\
\text { porting bias) }\end{array}$ & Unclear risk & Only aggregate data presented \\
\hline
\end{tabular}


Alvarez Rios1997

\begin{tabular}{|c|c|c|}
\hline Methods & \multicolumn{2}{|l|}{$\begin{array}{l}\mathrm{RCT} \\
\text { Modified RSI } \\
\mathrm{N}=60\end{array}$} \\
\hline Participants & \multicolumn{2}{|l|}{$\begin{array}{l}\text { ASA I - II } \\
\text { Elective OR } \\
\text { Mean age } 28.5 \\
\text { Mean weight } 62.5 \mathrm{~kg}\end{array}$} \\
\hline Interventions & \multicolumn{2}{|c|}{$\begin{array}{l}\text { 1. Rocuronium } 0.6 \mathrm{mg} / \mathrm{kg}(\mathrm{n}=20) \\
\text { 2. Mivacurium } 0.25 \mathrm{mg} / \mathrm{kg}(\mathrm{n}=20)^{\star} \\
\text { 3. Succinylcholine } 1 \mathrm{mg} / \mathrm{kg}(\mathrm{n}=20) \\
\text { Premedication: } \\
\text { midazolam } 2 \mathrm{mg}\end{array}$} \\
\hline Outcomes & \multicolumn{2}{|c|}{$\begin{array}{l}\text { 1. Intubating conditions } 90 \text { s after muscle relaxant. Reported as excellent, good, poor with definitions } \\
\text { described for madibular relaxation, vocal cords and participant movement }\end{array}$} \\
\hline Adverse events & \multicolumn{2}{|l|}{ None reported. } \\
\hline Time \& Place & $\begin{array}{l}\text { Study dates were not } r \\
\text { Mexico }\end{array}$ & 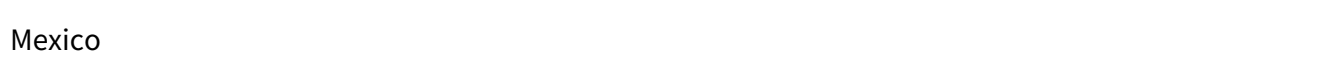 \\
\hline Funding and declarations & \multicolumn{2}{|c|}{ Declarations of interest: none declared } \\
\hline Notes & \multicolumn{2}{|l|}{ Efficacy analysis } \\
\hline \multicolumn{3}{|l|}{ Risk of bias } \\
\hline Bias & Authors' judgement & Support for judgement \\
\hline $\begin{array}{l}\text { Random sequence genera- } \\
\text { tion (selection bias) }\end{array}$ & Unclear risk & Established groups were formed randomly, but does not state how \\
\hline $\begin{array}{l}\text { Allocation concealment } \\
\text { (selection bias) }\end{array}$ & High risk & No comment made \\
\hline $\begin{array}{l}\text { Blinding of participants } \\
\text { and personnel (perfor- } \\
\text { mance bias) } \\
\text { All outcomes }\end{array}$ & Low risk & $\begin{array}{l}\text { Participant asleep and personnel performance does not affect intubating con- } \\
\text { ditions }\end{array}$ \\
\hline $\begin{array}{l}\text { Blinding of outcome as- } \\
\text { sessment (detection bias) } \\
\text { All outcomes }\end{array}$ & High risk & No statement regarding blinding \\
\hline $\begin{array}{l}\text { Incomplete outcome data } \\
\text { (attrition bias) } \\
\text { All outcomes }\end{array}$ & Low risk & Data on all participants reported \\
\hline
\end{tabular}


Alvarez Rios1997 (Continued)

Selective reporting (re- Low risk All outcomes reported
porting bias)

Andrews 1999

\begin{tabular}{ll}
\hline Methods & RCT \\
& Simulated RSI \\
& $\mathrm{N}=366$
\end{tabular}

\begin{tabular}{|c|c|}
\hline Outcomes & $\begin{array}{l}\text { 1. Intubating conditions } 50 \text { s after muscle relaxant. Reported as excellent, good, poor based on } 6 \text { vari- } \\
\text { ables (jaw relaxation, resistance to laryngoscope, vocal cord position and movement, limb movement } \\
\text { and diaphragmatic activity) with definitions described }\end{array}$ \\
\hline
\end{tabular}

Adverse events None reported.

Time \& Place Study dates not reported. Article accepted September 1998.

University of Newcastle-upon-Tyne, Turnhout, Belgium

\section{Funding and declarations Funding source: Organon Teknika}

Declarations of interest: none declared

Notes Efficacy analysis

\section{Risk of bias}

\begin{tabular}{lll}
\hline Bias & Authors' judgement & Support for judgement \\
\hline $\begin{array}{l}\text { Random sequence genera- } \\
\text { tion (selection bias) }\end{array}$ & Low risk & States randomly without replacement and stratified for centre \\
\hline $\begin{array}{l}\text { Allocation concealment } \\
\text { (selection bias) }\end{array}$ & Low risk & Allocation concealed from investigator performing the randomization \\
\hline $\begin{array}{l}\text { Blinding of participants } \\
\text { and personnel (perfor- } \\
\text { mance bias) }\end{array}$ & Low risk & $\begin{array}{l}\text { Participant asleep and personnel performance does not affect intubating con- } \\
\text { ditions }\end{array}$ \\
\hline
\end{tabular}

\begin{tabular}{|c|c|c|}
\hline $\begin{array}{l}\text { Blinding of outcome as- } \\
\text { sessment (detection bias) } \\
\text { All outcomes }\end{array}$ & Low risk & $\begin{array}{l}\text { "blinding was achieved by concealing patient from the investigator until im- } \\
\text { mediately before laryngoscopy." }\end{array}$ \\
\hline
\end{tabular}


Andrews 1999 (Continued)
Incomplete outcome data
Low risk
All participants accounted for
(attrition bias)

All outcomes

Selective reporting (re- Low risk $\quad$ All outcomes reported
porting bias)

\section{Belyamani 2008}

\begin{tabular}{ll}
\hline Methods & RCT \\
Simulated RSI \\
$\mathrm{N}=80$ \\
\hline
\end{tabular}

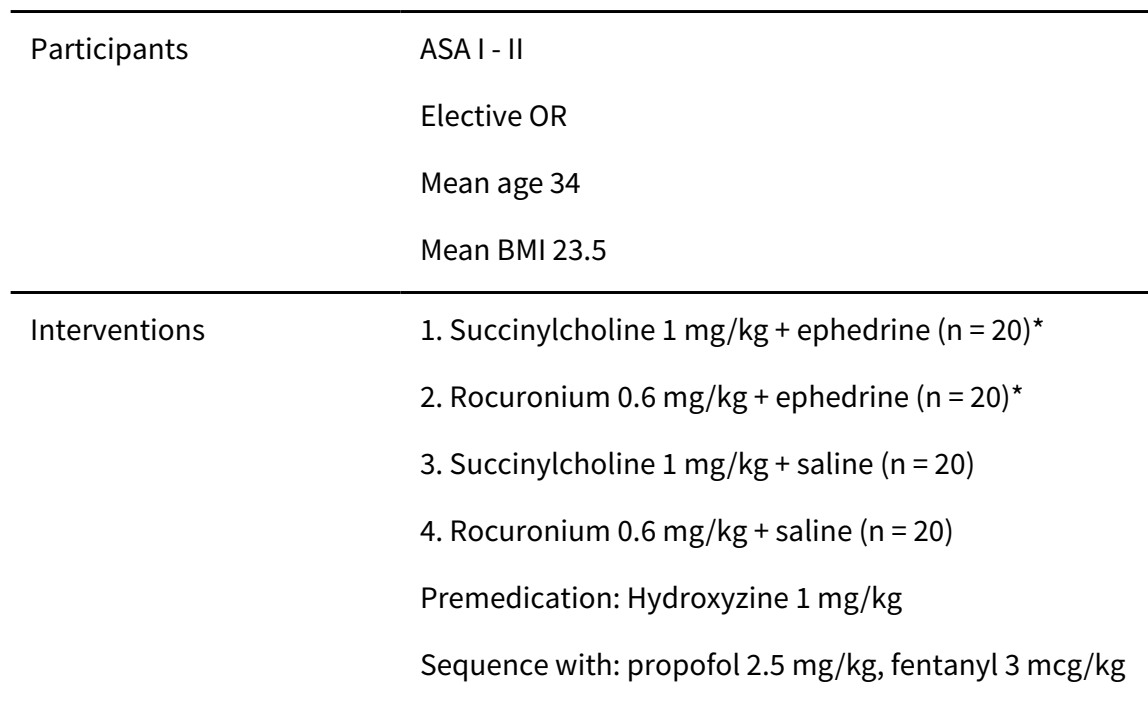

Outcomes $\quad$ 1. Intubation conditions 30 s after muscle relaxant. Reported as excellent, good, poor based on criteria from the Copenhagen conference. No definitions provided

2. Heart rate, blood pressure

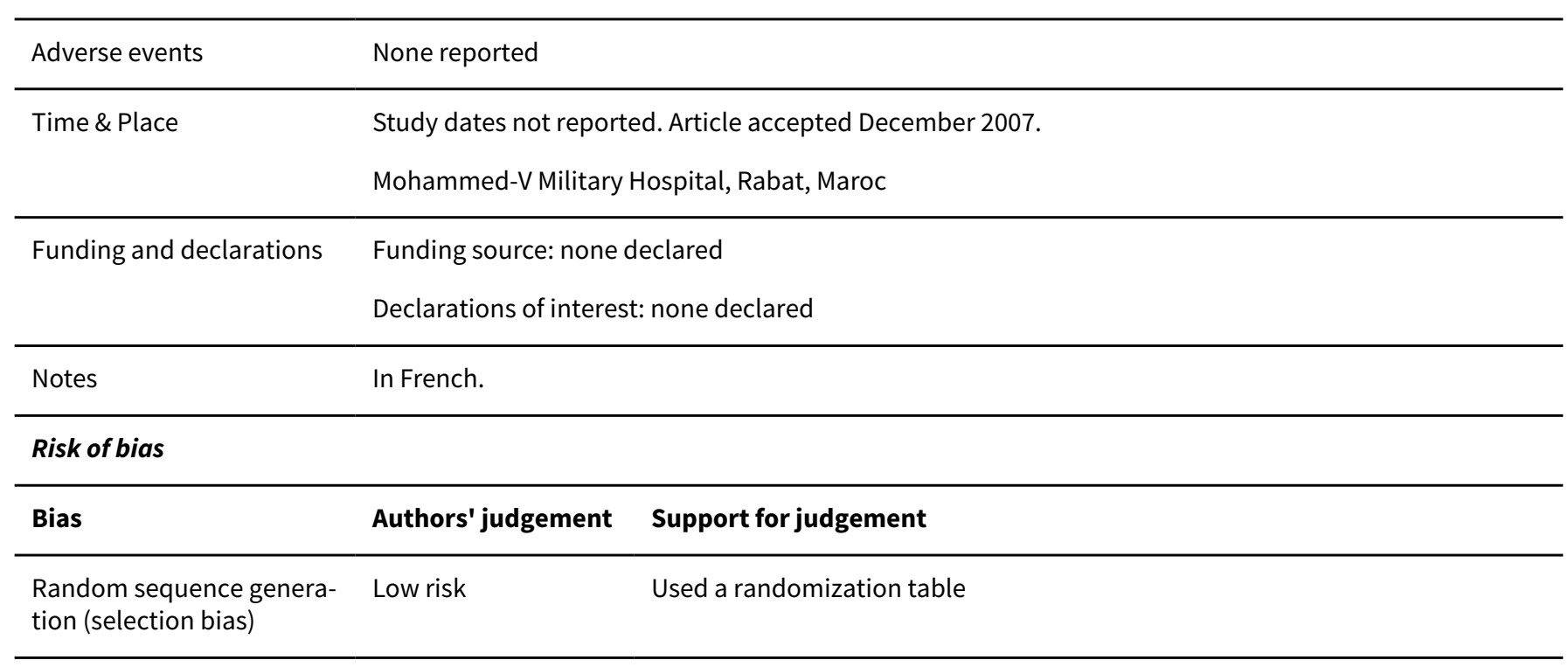


Belyamani 2008 (Continued)

$\begin{array}{ll}\begin{array}{l}\text { Allocation concealment } \\ \text { (selection bias) }\end{array} & \begin{array}{l}\text { The participant and the anaesthesiologist were not informed of the contents } \\ \text { of the syringes (prepared by a separate individual) }\end{array}\end{array}$

Blinding of participants Low risk
and personnel (performance bias)

All outcomes

Participant asleep and personnel performance does not affect intubating conditions

\begin{tabular}{lll}
\hline $\begin{array}{l}\text { Blinding of outcome as- } \\
\text { sessment (detection bias) } \\
\text { All outcomes }\end{array}$ & Low risk & $\begin{array}{l}\text { 30s after injection of the muscle relaxant, another blinded staff anaesthetist } \\
\text { performed intubation of the participant }\end{array}$ \\
\hline $\begin{array}{l}\text { Incomplete outcome data } \\
\begin{array}{l}\text { (attrition bias) } \\
\text { All outcomes }\end{array}\end{array}$ & Low risk & All cases reported \\
\hline $\begin{array}{l}\text { Selective reporting (re- } \\
\text { porting bias) }\end{array}$ & Low risk & All outcomes reported \\
\hline
\end{tabular}

\section{Cheng 2002}

\begin{tabular}{ll}
\hline Methods & RCT \\
& Modified RSI \\
& $\mathrm{N}=120$ \\
\hline Participants & ASA I \\
& $1-10$ years \\
& Elective OR \\
\hline Interventions & 1. Rocuronium $0.6 \mathrm{mg} / \mathrm{kg}(\mathrm{n}=40)$ \\
& 2. Rocuronium $0.9 \mathrm{mg} / \mathrm{kg}(\mathrm{n}=40)$ \\
& 3. Succinylcholine $1.5 \mathrm{mg} / \mathrm{kg}(\mathrm{n}=40)$ \\
& Sequence with: alfentanil $10 \mathrm{mcg} / \mathrm{kg}$, thiopentone $5 \mathrm{mg} / \mathrm{kg}$
\end{tabular}

\begin{tabular}{ll}
\hline Outcomes & $\begin{array}{l}\text { 1. Intubating conditions } 30 \text { s after muscle relaxant. Reported as excellent, good, poor and impossible } \\
\text { with table of definitions. Clinical features included: vocal cord movement, participant response to intu- } \\
\text { bation and jaw relaxation }\end{array}$
\end{tabular}

Adverse events $\quad$ One participant developed bronchospasm during intubation after receiving rocuronium $0.9 \mathrm{mg} / \mathrm{kg}$.
This resolved spontaneously.

Time \& Place Study dates not reported. Article published 2002.

Prince of Wales Hospital, New Territories, Hong Kong

Funding and declarations $\quad$ Funding source: Organon Teknika China Ltd provided rocuronium for study.

Declarations of interest: none declared

\begin{tabular}{ll}
\hline Notes & ITT analysis \\
\hline Risk of bias & \\
\hline Bias & Authors' judgement Support for judgement \\
\hline
\end{tabular}


Cheng 2002 (Continued)

\begin{tabular}{l}
$\begin{array}{l}\text { Random sequence genera- } \\
\text { tion (selection bias) }\end{array}$ Low risk Randomized by sealed envelopes \\
\hline
\end{tabular}

Allocation concealment Low risk "children were randomly assigned by means of opaque, sealed envelopes"
(selection bias)

(selection bias)

\begin{tabular}{lll}
\hline $\begin{array}{l}\text { Blinding of participants } \\
\text { and personnel (perfor- }\end{array}$ & Low risk & $\begin{array}{l}\text { Participant asleep and personnel performance does not affect intubating con- } \\
\text { ditions }\end{array}$
\end{tabular}

mance bias)

All outcomes

\begin{tabular}{|c|c|c|}
\hline $\begin{array}{l}\text { Blinding of outcome as- } \\
\text { sessment (detection bias) } \\
\text { All outcomes }\end{array}$ & Low risk & $\begin{array}{l}\text { "observer had her back turned to the patient during the } 30 \text { s before attempting } \\
\text { to intubate" }\end{array}$ \\
\hline $\begin{array}{l}\text { Incomplete outcome data } \\
\text { (attrition bias) } \\
\text { All outcomes }\end{array}$ & Low risk & All cases reported \\
\hline $\begin{array}{l}\text { Selective reporting (re- } \\
\text { porting bias) }\end{array}$ & Low risk & All outcomes reported \\
\hline
\end{tabular}

Chiu 1999

\begin{tabular}{|c|c|}
\hline Methods & $\begin{array}{l}\mathrm{RCT} \\
\text { Simulated RSI } \\
\mathrm{N}=30\end{array}$ \\
\hline Participants & $\begin{array}{l}\text { ASA I } \\
18 \text { - } 50 \text { years } \\
\text { Elective OR } \\
\text { Mean age } 32.4 \\
\text { Mean weight } 55.6 \mathrm{~kg}\end{array}$ \\
\hline Interventions & $\begin{array}{l}\text { 1. Rocuronium } 0.9 \mathrm{mg} / \mathrm{kg}(\mathrm{n}=15) \\
\text { 2. Succinylcholine } 1 \mathrm{mg} / \mathrm{kg}(\mathrm{n}=15) \\
\text { Premedication: midazolam } 0.15 \mathrm{mg} / \mathrm{kg} \text { po } \\
\text { Sequence with: fentanyl } 2 \mathrm{mcg} / \mathrm{kg} \text {, propofol } 2 \mathrm{mg} / \mathrm{kg}\end{array}$ \\
\hline Outcomes & $\begin{array}{l}\text { 1. Intraocular pressure, mean arterial pressure, heart rate measured before induction, immediately af- } \\
\text { ter induction and every minute after intubation for } 5 \text { mins } \\
\text { 2. Intubating conditions } 60 \text { s after muscle relaxant. Reported as a score }(1-4) \text { described in Methods sec- } \\
\text { tion. Clinical variables included jaw relaxation, vocal cord movement, diaphragm movement }\end{array}$ \\
\hline Adverse events & None reported. \\
\hline Time \& Place & $\begin{array}{l}\text { Study dates not reported. Article accepted January } 1999 . \\
\text { Univeristy of Malaya, Kuala Lumpur, Malaysia }\end{array}$ \\
\hline Funding and declarations & $\begin{array}{l}\text { Funding source: Organon Teknika (Malaysia) supplied rocuronium. Kemajuan Abadi Optomedic } \\
\text { (Malaysia) supplied Keeler Pulsair air pulse tonometer. } \\
\text { Declarations of interest: none declared }\end{array}$ \\
\hline
\end{tabular}


Chiu 1999 (Continued)
Notes
Efficacy analysis

\section{Risk of bias}

\begin{tabular}{|c|c|c|}
\hline Bias & Authors' judgement & Support for judgement \\
\hline $\begin{array}{l}\text { Random sequence genera- } \\
\text { tion (selection bias) }\end{array}$ & Unclear risk & "randomized, double-blind, controlled study", but does not elaborate \\
\hline $\begin{array}{l}\text { Allocation concealment } \\
\text { (selection bias) }\end{array}$ & Low risk & $\begin{array}{l}\text { "drugs were administered ...by one anaesthetist (CYW) who was unaware of } \\
\text { the drugs administered" }\end{array}$ \\
\hline $\begin{array}{l}\text { Blinding of participants } \\
\text { and personnel (perfor- } \\
\text { mance bias) } \\
\text { All outcomes }\end{array}$ & Low risk & $\begin{array}{l}\text { Participant asleep and personnel performance does not affect intubating con- } \\
\text { ditions }\end{array}$ \\
\hline $\begin{array}{l}\text { Blinding of outcome as- } \\
\text { sessment (detection bias) } \\
\text { All outcomes }\end{array}$ & Low risk & $\begin{array}{l}\text { "the intubating anesthetist were not allowed to observe injection of the neu- } \\
\text { romuscular blocking drug or the presence of any fasciculations, by standing } \\
\text { initially with their back to the patient. They were then asked to turn round to } \\
\text { face the patient, } 45 \mathrm{~s} \text { after injection of either succinylcholine or rocuronium; by } \\
\text { then the fasciculations had subsided" }\end{array}$ \\
\hline $\begin{array}{l}\text { Incomplete outcome data } \\
\text { (attrition bias) } \\
\text { All outcomes }\end{array}$ & Low risk & All cases reported \\
\hline $\begin{array}{l}\text { Selective reporting (re- } \\
\text { porting bias) }\end{array}$ & Low risk & All outcomes reported \\
\hline
\end{tabular}

\section{Chung 2001}

\begin{tabular}{ll}
\hline Methods & $\begin{array}{l}\text { RCT } \\
\text { Simulated RSI } \\
\mathrm{N}=84\end{array}$ \\
\hline Participants & $\begin{array}{l}\text { ASA I - II } \\
\text { Edult } \\
\text { Mective OR }\end{array}$ \\
\hline Interventions & $\begin{array}{l}\text { 1. Rocuronium } 0.6 \mathrm{mg} / \mathrm{kg} \text { and then thiopental } 5 \mathrm{mg} / \mathrm{kg}(\mathrm{n}=28)^{\star} \\
\text { 2. Thiopental } 5 \mathrm{mg} / \mathrm{kg} \text { and then succinylcholine } 1 \mathrm{mg} / \mathrm{kg}(\mathrm{n}=29)\end{array}$ \\
$\begin{array}{l}\text { 3. Thiopental } 5 \mathrm{mg} / \mathrm{kg} \text { and then rocuronium } 0.6 \mathrm{mg} / \mathrm{kg}(\mathrm{n}=27) \\
\text { Sequence with: fentanyl } 2 \mathrm{mcg} / \mathrm{kg} \text {, lidocaine } 20 \mathrm{mg}\end{array}$ \\
$\begin{array}{l}\text { 1. Intubating conditions } 60 \mathrm{~s} \text { after muscle relaxant. } \mathrm{Reported} \text { as excellent, good and poor from a score }(0 \\
\text { - 9) (from Cooper et al ) based on } 3 \text { variables (ease of laryngoscopy, condition of vocal cords, response } \\
\text { to intubation) and defined in a table }\end{array}$ \\
$\begin{array}{l}\text { 2. Apnea time before laryngoscopy } \\
\text { 3. Intubation time } \\
\text { 4. Total apnoea time }\end{array}$
\end{tabular}


Chung 2001 (Continued)

$\begin{array}{ll}\text { Adverse events } & 5 \text { participants in Group } 1 \text { and } 1 \text { in Group } 2 \text { had pain in injection. } 3 \text { in Group } 1 \text { had diminished breathing } \\ \text { during induction. } 1 \text { in Group } 1 \text { had mild desaturation. }\end{array}$
during induction. 1 in Group 1 had mild desaturation.

Time \& Place

Study dates not reported. Article accepted September 2000.

Changhua Christian Hospital, Changhau, Taiwan

$\begin{array}{ll}\text { Funding and declarations } & \begin{array}{l}\text { Funding source: none declared } \\ \text { Declarations of interest: none declared }\end{array}\end{array}$

Notes Efficacy analysis

\section{Risk of bias}

\begin{tabular}{|c|c|c|}
\hline Bias & Authors' judgement & Support for judgement \\
\hline $\begin{array}{l}\text { Random sequence genera- } \\
\text { tion (selection bias) }\end{array}$ & Unclear risk & "patients were randomly allocated", but did not elaborate \\
\hline $\begin{array}{l}\text { Allocation concealment } \\
\text { (selection bias) }\end{array}$ & High risk & Not mentioned \\
\hline $\begin{array}{l}\text { Blinding of participants } \\
\text { and personnel (perfor- } \\
\text { mance bias) } \\
\text { All outcomes }\end{array}$ & Low risk & $\begin{array}{l}\text { Participant asleep and personnel performance does not affect intubating con- } \\
\text { ditions }\end{array}$ \\
\hline $\begin{array}{l}\text { Blinding of outcome as- } \\
\text { sessment (detection bias) } \\
\text { All outcomes }\end{array}$ & High risk & Not mentioned \\
\hline $\begin{array}{l}\text { Incomplete outcome data } \\
\text { (attrition bias) } \\
\text { All outcomes }\end{array}$ & Low risk & $\begin{array}{l}\text { All participants accounted for, } 6 / 90 \text { participants excluded due to "invisible vo- } \\
\text { cal cords after several attempts" }\end{array}$ \\
\hline $\begin{array}{l}\text { Selective reporting (re- } \\
\text { porting bias) }\end{array}$ & Low risk & All outcomes reported \\
\hline
\end{tabular}

\section{Cooper 1992}

\begin{tabular}{ll}
\hline Methods & RCT \\
& Modified RSI \\
& $\mathrm{N}=80$ \\
\hline Participants & ASA I - II \\
& $18-65$ years \\
& Elective OR \\
& Mean age 34.5 \\
& Mean weight $66.3 \mathrm{~kg}$ \\
\hline Interventions & 1. Rocuronium $0.6 \mathrm{mg} / \mathrm{kg}(\mathrm{n}=40)$ \\
& 2. Succinylcholine $1 \mathrm{mg} / \mathrm{kg}(\mathrm{n}=40)$ \\
& Premedication: temazepam $10-20 \mathrm{mg}$ po \\
& Sequence with: fentanyl $1-3 \mathrm{mcg} / \mathrm{kg}$, thiopentone $3-5 \mathrm{mg} / \mathrm{kg}$ \\
\hline
\end{tabular}


Cooper 1992 (Continued)

Outcomes $\quad$ 1. Intubating conditions 60 and 90 s after muscle relaxant. Reported as excellent, good and poor from a score ( 0 - 9 ) based on 3 variables (jaw relaxation, vocal cords, response to intubation), defined in table

\begin{tabular}{|c|c|c|}
\hline Adverse events & \multicolumn{2}{|l|}{ None reported. } \\
\hline Time \& Place & \multicolumn{2}{|c|}{$\begin{array}{l}\text { Study dates not reported. Article accepted March } 1992 . \\
\text { Queen's University, Belfast, Britain }\end{array}$} \\
\hline Funding and declarations & \multicolumn{2}{|c|}{$\begin{array}{l}\text { Funding source: rocuronium supplied by Organon Teknika, Belgium } \\
\text { Declarations of interest: none declared }\end{array}$} \\
\hline Notes & \multicolumn{2}{|l|}{ Efficacy analysis } \\
\hline \multicolumn{3}{|l|}{ Risk of bias } \\
\hline Bias & Authors' judgement & Support for judgement \\
\hline $\begin{array}{l}\text { Random sequence genera- } \\
\text { tion (selection bias) }\end{array}$ & Unclear risk & "patients were allocated randomly" \\
\hline $\begin{array}{l}\text { Allocation concealment } \\
\text { (selection bias) }\end{array}$ & Unclear risk & "patients were allocated randomly" \\
\hline $\begin{array}{l}\text { Blinding of participants } \\
\text { and personnel (perfor- } \\
\text { mance bias) } \\
\text { All outcomes }\end{array}$ & Low risk & $\begin{array}{l}\text { Participant asleep and personnel performance does not affect intubating con- } \\
\text { ditions }\end{array}$ \\
\hline $\begin{array}{l}\text { Blinding of outcome as- } \\
\text { sessment (detection bias) } \\
\text { All outcomes }\end{array}$ & High risk & No comment on blinding \\
\hline $\begin{array}{l}\text { Incomplete outcome data } \\
\text { (attrition bias) } \\
\text { All outcomes }\end{array}$ & Low risk & All cases reported \\
\hline $\begin{array}{l}\text { Selective reporting (re- } \\
\text { porting bias) }\end{array}$ & Low risk & All outcomes reported \\
\hline
\end{tabular}

De Almeida 2009

\begin{tabular}{ll}
\hline Methods & Controlled Trial \\
& Simulated RSI \\
& $\mathrm{N}=80$ \\
\hline Participants & ASA I - III \\
& Elective bariatric surgery \\
& Morbidly obese participants BMI $\geq 40$ \\
& 18 - 65 yrs \\
Mean age 39
\end{tabular}


De Almeida 2009 (Continued)

Mean weight $128 \mathrm{~kg}$

Interventions Succinylcholine $1 \mathrm{mg} / \mathrm{kg}$ ideal body weight $(\mathrm{n}=20)^{*}$
2. Succinylcholine $1 \mathrm{mg} / \mathrm{kg}$ total body weight $(\mathrm{n}=20)$
3. Rocuronium $0.6 \mathrm{mg} / \mathrm{kg}$ ideal body weight $(\mathrm{n}=20)^{*}$
4. Rocuronium $0.6 \mathrm{mg} / \mathrm{kg}$ total body weight $(\mathrm{n}=20)$
Premedication: midazolam $7.5 \mathrm{mg}$
Sequence with: propofol $2 \mathrm{mg} / \mathrm{kg}$, fentanyl $2 \mathrm{mcg} / \mathrm{kg}$

Outcomes Intubation conditions 60s after intubation. Reported as excellent, good, poor based on 5 variables (laryngoscopy, vocal cord position, vocal cord movement, reaction to tube insertion, limb movement with tube insertion) described in a table

\begin{tabular}{ll}
\hline Adverse events & None reported. \\
\hline Time \& Place & March 2005 to March 2007. \\
& Federal University of Santa Catarina, Santa Catarina, Brazil \\
\hline Funding and declarations & Funding source: none declared \\
& Declarations of interest: none declared \\
\hline Notes & Paper written in Spanish.
\end{tabular}

\section{Risk of bias}

\begin{tabular}{|c|c|c|}
\hline Bias & Authors' judgement & Support for judgement \\
\hline $\begin{array}{l}\text { Random sequence genera- } \\
\text { tion (selection bias) }\end{array}$ & High risk & No mention of randomization \\
\hline $\begin{array}{l}\text { Allocation concealment } \\
\text { (selection bias) }\end{array}$ & High risk & No comment made \\
\hline $\begin{array}{l}\text { Blinding of participants } \\
\text { and personnel (perfor- } \\
\text { mance bias) } \\
\text { All outcomes }\end{array}$ & Low risk & $\begin{array}{l}\text { Participant asleep and personnel performance does not affect intubating con- } \\
\text { ditions. }\end{array}$ \\
\hline $\begin{array}{l}\text { Blinding of outcome as- } \\
\text { sessment (detection bias) } \\
\text { All outcomes }\end{array}$ & High risk & No description or comment on blinding \\
\hline $\begin{array}{l}\text { Incomplete outcome data } \\
\text { (attrition bias) } \\
\text { All outcomes }\end{array}$ & Low risk & All cases reported \\
\hline $\begin{array}{l}\text { Selective reporting (re- } \\
\text { porting bias) }\end{array}$ & Low risk & All outcomes reported \\
\hline
\end{tabular}


Dubois 1995

\begin{tabular}{|c|c|}
\hline Methods & $\begin{array}{l}\text { RCT } \\
\text { Modified RSI } \\
\mathrm{N}=24\end{array}$ \\
\hline Participants & $\begin{array}{l}\text { ASA I - II } \\
18 \text { - } 65 \text { years } \\
\text { Elective OR } \\
\text { Baseline information not provided (told groups tested and no difference) }\end{array}$ \\
\hline Interventions & $\begin{array}{l}\text { 1. Rocuronium } 0.6 \mathrm{mg} / \mathrm{kg}(\mathrm{n}=12) \\
\text { 2. Succinylcholine } 1 \mathrm{mg} / \mathrm{kg}(\mathrm{n}=12) \\
\text { Premedication: midazolam } 2-5 \mathrm{mg} \text { iv and/or droperidol } 1.25 \text { - } 5 \mathrm{mg} \text { iv } \\
\text { Sequence with: fentanyl } 1-10 \mathrm{mcg} / \mathrm{kg} \text {, thiopentone } 3-5 \mathrm{mg} / \mathrm{kg}\end{array}$ \\
\hline Outcomes & $\begin{array}{l}\text { 1. Intubating conditions after } 80 \% \text { first twitch depression of TOF. Reported as excellent good, poor and } \\
\text { inadequate based } 3 \text { variables (jaw relaxation, vocal cord movement, diaphragm) described in Methods } \\
\text { section } \\
\text { 2. Heart rate and blood pressure } \\
\text { 2. Onset time of muscle relaxant }\end{array}$ \\
\hline
\end{tabular}

\begin{tabular}{ll}
\hline Adverse events & 5 participants had fasciculations. 2 had skin rash and one experienced hypersalivation. \\
\hline Time \& Place & Study dates not reported. Article accepted March 1994. \\
& Georgetown University Medical Center, Washington, DC, USA. \\
\hline Funding and declarations & Funding source: Support of Clinical Project Director Organon Inc. \\
& Declarations of interest: none declared \\
\hline Notes & Efficacy analysis \\
\hline
\end{tabular}

\section{Risk of bias}

\begin{tabular}{|c|c|c|}
\hline Bias & Authors' judgement & Support for judgement \\
\hline $\begin{array}{l}\text { Random sequence genera- } \\
\text { tion (selection bias) }\end{array}$ & Low risk & Randomly assigned via computer generation \\
\hline $\begin{array}{l}\text { Allocation concealment } \\
\text { (selection bias) }\end{array}$ & Low risk & "either R or S in a coded syringe prepared by the pharmacist was given" \\
\hline $\begin{array}{l}\text { Blinding of participants } \\
\text { and personnel (perfor- } \\
\text { mance bias) } \\
\text { All outcomes }\end{array}$ & Low risk & $\begin{array}{l}\text { Participant asleep and personnel performance does not affect intubating con- } \\
\text { ditions }\end{array}$ \\
\hline $\begin{array}{l}\text { Blinding of outcome as- } \\
\text { sessment (detection bias) } \\
\text { All outcomes }\end{array}$ & Low risk & $\begin{array}{l}\text { "the investigator intubator was blinded to the muscle relaxant randomization } \\
\text { scheme and not in the operating room for drug administration" }\end{array}$ \\
\hline $\begin{array}{l}\text { Incomplete outcome data } \\
\text { (attrition bias) } \\
\text { All outcomes }\end{array}$ & Unclear risk & $\begin{array}{l}\text { "The other } 6 \text { patients were dropped because of incomplete data retrieval". Did } \\
\text { not say why data were missing }\end{array}$ \\
\hline
\end{tabular}


Dubois 1995 (Continued)

Selective reporting (re- Unclear risk $\quad$ Outcomes for excluded participants not reported
porting bias)
porting bias)

Giudice 1998

\begin{tabular}{ll}
\hline Methods & RCT \\
& Modified RSI \\
& N $=40$ \\
\hline Participants & ASA I - II \\
& Age 18 - 56 \\
& Mean age uncertain but told groups homogeneous \\
& Mean weight also homogeneous
\end{tabular}

Interventions
2. Rocuronium $0.3 \mathrm{mg} / \mathrm{kg}(\mathrm{n}=10)^{\star}$
3. Rocuronium $0.6 \mathrm{mg} / \mathrm{kg}(\mathrm{n}=10)$
4. Succinylcholine $1 \mathrm{mg} / \mathrm{kg}(\mathrm{kg}=10)$
Premedication: lorazepam $1 \mathrm{mg}$ po 1 hour prior, atropine $0.08 \mathrm{mg} / \mathrm{kg}$ few minutes prior
Sequence with: fentanyl prn, propofol $1.5 \mathrm{mg} / \mathrm{kg}$

\begin{tabular}{|c|c|}
\hline \multirow[t]{4}{*}{ Outcomes } & $\begin{array}{l}\text { 1. Intubating conditions when T1 of TOF } \leq 5 \% \text {. Reported as a score }(0-6) \text {. Variables not presented for } \\
\text { score assessment }\end{array}$ \\
\hline & 2. Recovery of $\mathrm{T} 1$ to $25 \%$ \\
\hline & 3. Intubating time \\
\hline & 4. Recovery time \\
\hline
\end{tabular}

Adverse events None reported.

\begin{tabular}{ll}
\hline Time \& Place & Study dates not reported. Article accepted August 1998. \\
& Italy \\
\hline Funding and declarations & $\begin{array}{l}\text { Funding source: none declared } \\
\text { Declarations of interest: none declared }\end{array}$ \\
\hline Notes & Italian \\
\hline
\end{tabular}

\section{Risk of bias}

\begin{tabular}{lll}
\hline Bias & Authors' judgement & Support for judgement \\
\hline $\begin{array}{l}\text { Random sequence genera- } \\
\text { tion (selection bias) }\end{array}$ & Unclear risk & "patients were randomly allocated into four groups" \\
\hline $\begin{array}{l}\text { Allocation concealment } \\
\text { (selection bias) }\end{array}$ & High risk & Not mentioned \\
\hline $\begin{array}{l}\text { Blinding of participants } \\
\text { and personnel (perfor- } \\
\text { mance bias) }\end{array}$ & Low risk & Participant asleep and personnel performance does not affect intubating con- \\
$\begin{array}{l}\text { All outcomes } \\
\text { ditions }\end{array}$ &
\end{tabular}


Giudice 1998 (Continued)

\begin{tabular}{lll}
$\begin{array}{l}\text { Blinding of outcome as- } \\
\text { sessment (detection bias) } \\
\text { All outcomes }\end{array}$ & High risk & No comment \\
\hline $\begin{array}{l}\text { Incomplete outcome data } \\
\begin{array}{l}\text { (attrition bias) } \\
\text { All outcomes }\end{array}\end{array}$ & Low risk & All cases reported \\
\hline $\begin{array}{l}\text { Selective reporting (re- } \\
\text { porting bias) }\end{array}$ & Low risk & All outcomes reported \\
\hline
\end{tabular}

\section{Iqbal 2013}

\begin{tabular}{ll}
\hline Methods & RCT \\
& Simulated RSI \\
& $\mathrm{N}=60$ \\
\hline Participants & ASA I - II \\
& Adult elective surgery \\
& Age 20 - 60 yrs \\
\hline
\end{tabular}

Interventions Rocuronium $0.9 \mathrm{mg} / \mathrm{kg}(\mathrm{n}=30)$
2. Succinylcholine $1.5 \mathrm{mg} / \mathrm{kg}(\mathrm{n}=30)$
Sequence with: thiopental $5 \mathrm{mg} / \mathrm{kg}$
No premeds

$\begin{array}{ll}\text { Outcomes } & \text { Intubating conditions 60s after induction drugs. Reported as excellent, good, poor and not possible } \\ \text { based on } 3 \text { variables (jaw relaxation, vocal cords and response to tube) from modification of Goldberg } \\ \text { et and Krieg et al. }\end{array}$

\begin{tabular}{ll}
\hline Adverse events & None reported. \\
\hline Time \& Place & January to August 2009. \\
& Civil Hospital Karachi, Karachi, Pakistan \\
\hline
\end{tabular}

$\begin{array}{ll}\text { Funding and declarations } & \text { Funding source: none declared } \\ & \text { Declarations of interest: none declared }\end{array}$

\section{Notes}

\section{Risk of bias}

\section{Bias}

Authors' judgement Support for judgement

Random sequence genera- Unclear risk "randomized", did not elaborate


Iqbal 2013 (Continued)

\begin{tabular}{|c|c|c|}
\hline $\begin{array}{l}\text { Allocation concealment } \\
\text { (selection bias) }\end{array}$ & Low risk & "double-blind manner" \\
\hline $\begin{array}{l}\text { Blinding of participants } \\
\text { and personnel (perfor- } \\
\text { mance bias) } \\
\text { All outcomes }\end{array}$ & Low risk & $\begin{array}{l}\text { Participant asleep and personnel performance does not affect intubating con- } \\
\text { ditions }\end{array}$ \\
\hline $\begin{array}{l}\text { Blinding of outcome as- } \\
\text { sessment (detection bias) } \\
\text { All outcomes }\end{array}$ & Low risk & $\begin{array}{l}\text { "endotracheal intubation was done blinded by standing with the back to the } \\
\text { patient." }\end{array}$ \\
\hline $\begin{array}{l}\text { Incomplete outcome data } \\
\text { (attrition bias) } \\
\text { All outcomes }\end{array}$ & Low risk & All cases reported \\
\hline $\begin{array}{l}\text { Selective reporting (re- } \\
\text { porting bias) }\end{array}$ & Low risk & All outcomes reported \\
\hline
\end{tabular}

\section{Koroglu 2002}

\begin{tabular}{|c|c|}
\hline Methods & $\begin{array}{l}\text { RCT } \\
\text { Simulated RSI } \\
\mathrm{N}=80\end{array}$ \\
\hline Participants & $\begin{array}{l}\text { ASA I - II } \\
\text { Adult women } \\
\text { Pregnant }\end{array}$ \\
\hline Interventions & $\begin{array}{l}\text { 1. Rocuronium } 0.6 \mathrm{mg} / \mathrm{kg} \text { and propofol } 2 \mathrm{mg} / \mathrm{kg}(\mathrm{n}=20) \\
\text { 2. Succinylcholine } 1.5 \mathrm{mg} / \mathrm{kg} \text { and propofol } 2 \mathrm{mg} / \mathrm{kg}(\mathrm{n}=20) \\
\text { 3. Rocuronium } 0.6 \mathrm{mg} / \mathrm{kg} \text { and thiopentone } 5 \mathrm{mg} / \mathrm{kg}(\mathrm{n}=20) \\
\text { 4. Succinylcholine } 1.5 \mathrm{mg} / \mathrm{kg} \text { and thiopentone } 5 \mathrm{mg} / \mathrm{kg}(\mathrm{n}=20)\end{array}$ \\
\hline
\end{tabular}

Outcomes $\begin{aligned} & \text { 1. Intubations conditions. Started intubation 20s after muscle relaxant, intubated according to clinical } \\ & \text { conditions. Reported as excellent, good, poor based on } 3 \text { variables (jaw relaxation, vocal cord move- } \\ & \text { ment, reaction to tube) and score }(0-9) \text { from Cooper et al. } \\ & \text { 2. Time to intubations } \\ & \text { 3. Neuromuscular conduction in musculus adductor pollicis by TOF } \\ & \text { 3. Umbilical arterial and venous blood gas values }\end{aligned}$

\begin{tabular}{ll}
\hline Adverse events & None reported. \\
\hline Time \& Place & Study dates not reported. Article published 2002. \\
& Dokuz Eylul University, Turkey \\
\hline Funding and declarations & $\begin{array}{l}\text { Funding source: none declared } \\
\text { Declarations of interest: none declared }\end{array}$ \\
\hline Notes & $\begin{array}{l}\text { Efficacy analysis } \\
\text { In Turkish }\end{array}$ \\
\hline
\end{tabular}


Koroglu 2002 (Continued)

Risk of bias

\begin{tabular}{|c|c|c|}
\hline Bias & Authors' judgement & Support for judgement \\
\hline $\begin{array}{l}\text { Random sequence genera- } \\
\text { tion (selection bias) }\end{array}$ & High risk & "patients were numbered according to their order of arrival to the surgery" \\
\hline $\begin{array}{l}\text { Allocation concealment } \\
\text { (selection bias) }\end{array}$ & High risk & No comment made \\
\hline $\begin{array}{l}\text { Blinding of participants } \\
\text { and personnel (perfor- } \\
\text { mance bias) } \\
\text { All outcomes }\end{array}$ & Low risk & $\begin{array}{l}\text { Participant asleep and personnel performance does not affect intubating con- } \\
\text { ditions }\end{array}$ \\
\hline $\begin{array}{l}\text { Blinding of outcome as- } \\
\text { sessment (detection bias) } \\
\text { All outcomes }\end{array}$ & High risk & No comment made \\
\hline $\begin{array}{l}\text { Incomplete outcome data } \\
\text { (attrition bias) } \\
\text { All outcomes }\end{array}$ & Unclear risk & All cases were accounted for \\
\hline $\begin{array}{l}\text { Selective reporting (re- } \\
\text { porting bias) }\end{array}$ & Low risk & All outcomes reported \\
\hline
\end{tabular}

Kulkarni 2010

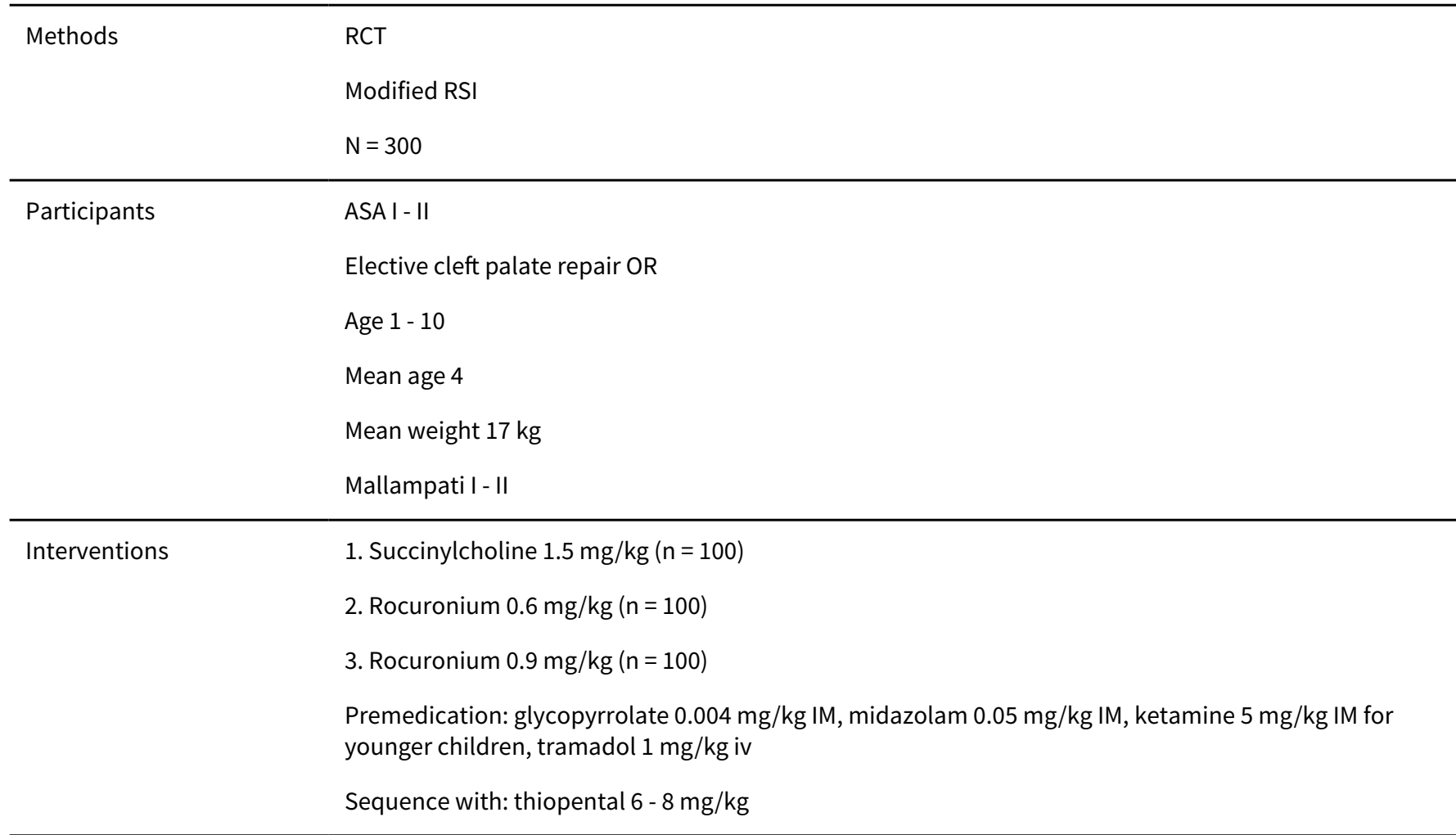


Kulkarni 2010 (Continued)

Outcomes $\quad 1$ Intubation conditions at 60 s after muscle relaxant. Reported as excellent, good, poor, inadequate according to intubation scoring system as per Mangorian et al. Based on 3 clinical variables: jaw relaxation, vocal cord movement and diaphragmatic movements

2. Intubation time

3. Duration of muscle relaxation with TOF monitoring

4. Clinical recovery

\begin{tabular}{ll}
\hline Adverse events & Tachycardia in all three groups $(58-66 \%)$ \\
\hline Time \& Place & October 2003 to September 2008. \\
& Lotus Hospital \& Research Center, Kolhapur, Maharashtra, India
\end{tabular}

Funding and declarations Funding source: none declared

Declarations of interest: none declared

Notes used oral RAE tubes

\section{Risk of bias}

\begin{tabular}{|c|c|c|}
\hline Bias & Authors' judgement & Support for judgement \\
\hline $\begin{array}{l}\text { Random sequence genera- } \\
\text { tion (selection bias) }\end{array}$ & Unclear risk & "randomly divided in three groups" \\
\hline $\begin{array}{l}\text { Allocation concealment } \\
\text { (selection bias) }\end{array}$ & High risk & No comment made \\
\hline $\begin{array}{l}\text { Blinding of participants } \\
\text { and personnel (perfor- } \\
\text { mance bias) } \\
\text { All outcomes }\end{array}$ & Low risk & $\begin{array}{l}\text { Participant asleep and personnel performance does not affect intubating con- } \\
\text { ditions }\end{array}$ \\
\hline $\begin{array}{l}\text { Blinding of outcome as- } \\
\text { sessment (detection bias) } \\
\text { All outcomes }\end{array}$ & High risk & No comment made \\
\hline $\begin{array}{l}\text { Incomplete outcome data } \\
\text { (attrition bias) } \\
\text { All outcomes }\end{array}$ & Low risk & All cases presented \\
\hline $\begin{array}{l}\text { Selective reporting (re- } \\
\text { porting bias) }\end{array}$ & Low risk & All outcomes reported \\
\hline
\end{tabular}

\section{Kwon 2013}

\begin{tabular}{ll}
\hline Methods & RCT \\
& Modified RSI \\
& $\mathrm{N}=40$ \\
\hline Participants & ASA I - II \\
\hline
\end{tabular}


Kwon 2013 (Continued)

\section{Elective OR}

Mean age 43

Mean weight $61 \mathrm{~kg}$

\begin{tabular}{ll}
\hline Interventions & $\begin{array}{l}\text { 1. Succinylcholine } 1.5 \mathrm{mg} / \mathrm{kg}(\mathrm{n}=20) \\
\text { 2. Rocuronium } 0.6 \mathrm{mg} / \mathrm{kg}(\mathrm{n}=20) \\
\text { Sequence with: lidocaine } 60 \mathrm{mg}, \text { fentanyl } 1.5 \mathrm{mcg} / \mathrm{kg}, \text { propofol } 1.5 \mathrm{mg} / \mathrm{kg}\end{array}$ \\
\hline Outcomes & $\begin{array}{l}\text { 1. Intubating conditions (with loss of consciousness for rocuronium group and } 60 \mathrm{~s} \text { after succinyl- } \\
\text { choline). Reported as excellent, acceptable and poor based on a score. Variables included: mandibular } \\
\text { relaxation, resistance to blade insertion, vocal cord position and movement, limb response, coughing }\end{array}$ \\
& $\begin{array}{l}\text { 2. Timing of events } \\
\text { 3. Complications of intubation: awareness, respiratory difficulty postoperatively }\end{array}$ \\
\hline Adverse events & S participants who received rocuronium complained of injection pain. \\
\hline Time \& Place & Dankook University, Cheonan, Korea \\
\hline
\end{tabular}

Funding and declarations Funding source: none declared

Declarations of interest: none declared

\section{Notes}

\section{Risk of bias}

\begin{tabular}{|c|c|c|}
\hline Bias & Authors' judgement & Support for judgement \\
\hline $\begin{array}{l}\text { Random sequence genera- } \\
\text { tion (selection bias) }\end{array}$ & Unclear risk & "patients were randomly assigned" \\
\hline $\begin{array}{l}\text { Allocation concealment } \\
\text { (selection bias) }\end{array}$ & Low risk & $\begin{array}{l}\text { "tracheal intubation were performed...by an experienced anesthesiologist } \\
\text { who was blinded to the anesthetic drug" }\end{array}$ \\
\hline $\begin{array}{l}\text { Blinding of participants } \\
\text { and personnel (perfor- } \\
\text { mance bias) } \\
\text { All outcomes }\end{array}$ & Low risk & $\begin{array}{l}\text { Participant asleep and personnel performance does not affect intubating con- } \\
\text { ditions }\end{array}$ \\
\hline $\begin{array}{l}\text { Blinding of outcome as- } \\
\text { sessment (detection bias) } \\
\text { All outcomes }\end{array}$ & Unclear risk & No blinding mentioned \\
\hline $\begin{array}{l}\text { Incomplete outcome data } \\
\text { (attrition bias) } \\
\text { All outcomes }\end{array}$ & Low risk & All cases were reported \\
\hline $\begin{array}{l}\text { Selective reporting (re- } \\
\text { porting bias) }\end{array}$ & Low risk & All outcomes reported \\
\hline
\end{tabular}


Lam 2000

\begin{tabular}{ll}
\hline Methods & RCT \\
& Modified RSI \\
& $\mathrm{N}=30$ \\
\hline Participants & ASA I - II \\
& $\begin{array}{l}\text { } 18 \text { - } 65 \text { years } \\
\text { Elective OR }\end{array}$ \\
\hline Interventions & 1. Rocuronium $0.6 \mathrm{mg} / \mathrm{kg}(\mathrm{n}=15)$ \\
& $\begin{array}{l}\text { 2. Succinylcholine } 1 \mathrm{mg} / \mathrm{kg}(\mathrm{n}=15) \\
\text { Premedication: } \mathrm{midazolam} 2 \mathrm{mg}\end{array}$ \\
& Sequence with: fentanyl $2 \mathrm{mcg} / \mathrm{kg}$, propofol $2.5 \mathrm{mg} / \mathrm{kg}$
\end{tabular}

Outcomes
blinded individual as excellent, good, poor and inadequate based on jaw relaxation, vocal cord position
and movement, and diaphragm movement
2. Onset muscle relaxation with TOF
3. Offset muscle relaxation with TOF

\begin{tabular}{ll}
\hline Adverse events & None reported. \\
\hline Time \& Place & Study dates not reported. Article accepted August 2000. \\
& University of Washington, Seattle, USA \\
\hline
\end{tabular}

\section{Funding and declarations Funding source: Organon West Orange, New Jersey}

Declarations of interest: none declared

\begin{tabular}{ll}
\hline Notes & Efficacy analysis \\
\hline Risk of bias &
\end{tabular}

\section{Risk of bias}

\begin{tabular}{|c|c|c|}
\hline Bias & Authors' judgement & Support for judgement \\
\hline $\begin{array}{l}\text { Random sequence genera- } \\
\text { tion (selection bias) }\end{array}$ & Low risk & Computer generated \\
\hline $\begin{array}{l}\text { Allocation concealment } \\
\text { (selection bias) }\end{array}$ & Low risk & Intubator unaware of drug \\
\hline $\begin{array}{l}\text { Blinding of participants } \\
\text { and personnel (perfor- } \\
\text { mance bias) } \\
\text { All outcomes }\end{array}$ & Low risk & $\begin{array}{l}\text { Participant asleep and personnel performance does not affect intubating con- } \\
\text { ditions }\end{array}$ \\
\hline $\begin{array}{l}\text { Blinding of outcome as- } \\
\text { sessment (detection bias) } \\
\text { All outcomes }\end{array}$ & High risk & "there were no attempts made to blind the individual" \\
\hline $\begin{array}{l}\text { Incomplete outcome data } \\
\text { (attrition bias) } \\
\text { All outcomes }\end{array}$ & Low risk & Complete data set \\
\hline $\begin{array}{l}\text { Selective reporting (re- } \\
\text { porting bias) }\end{array}$ & Low risk & All outcomes reported \\
\hline
\end{tabular}


Larsen 2005

\begin{tabular}{ll} 
Methods & $\begin{array}{l}\text { RCT } \\
\text { Simulated RSI } \\
\mathrm{N}=209\end{array}$ \\
\hline Participants & $\begin{array}{l}\text { ASA I - III } \\
\text { Emergency OR }\end{array}$ \\
\hline Interventions & $\begin{array}{l}\text { 1. Rocuronium } 0.6 \mathrm{mg} / \mathrm{kg}(\mathrm{n}=102) \\
\text { 2. Succinylcholine } 1 \mathrm{mg} / \mathrm{kg}(\mathrm{n}=107) \\
\text { Premedication: i.m morphine } 30 \text { mins prior } \\
\text { Sequence with: alfentanil } 10-20 \text { ug/kg, propofol } 2 \text { - } 3 \mathrm{mg} / \mathrm{kg}\end{array}$ \\
\hline Outcomes & $\begin{array}{l}\text { 1. Intubating conditions } 60 \mathrm{~s} \text { after muscle relaxant by senior anaesthesiologist. Intubations not } \\
\text { achieved in } 30 \text { s were recorded as failed. Reported as excellent, good, poor and first attempt failed. } \\
\text { Based on } 5 \text { variables: ease of laryngoscopy, position of vocal cords, movement of vocal cords, move- } \\
\text { ment of limbs and coughing during tracheal intubation } \\
\text { 2. Heart rate and blood pressure }\end{array}$
\end{tabular}

$\begin{array}{ll}\text { Adverse events } & 1 \text { participant in Group } 2 \text { had atrial fibrillation requiring treatment verapamil and sotalol. Hypotension } \\ \text { requiring treatment with ephedrine occurred in } 18 \text { Group2 and } 17 \text { Group } 1 \text {. Five participants in Grp } 2 \\ \text { and } 2 \text { in Group1 reported postoperative muscle pain. }\end{array}$

Time \& Place Study dates not reported. Article accepted June 2005.

University of Copenhagen, Glostrup, Denmark

Funding and declarations Funding source: none declared

Declarations of interest: none declared

Notes Efficacy analysis

\section{Risk of bias}

\begin{tabular}{lll}
\hline Bias & Authors' judgement & Support for judgement \\
\hline $\begin{array}{l}\text { Random sequence genera- } \\
\text { tion (selection bias) }\end{array}$ & Low risk & Sealed envelopes \\
\hline $\begin{array}{l}\text { Allocation concealment } \\
\text { (selection bias) }\end{array}$ & Low risk & The participant was allocated by the concealed envelope method \\
\hline $\begin{array}{l}\text { Blinding of participants } \\
\text { and personnel (perfor- } \\
\text { mance bias) }\end{array}$ & Low risk & $\begin{array}{l}\text { Participant asleep and personnel performance does not affect intubating con- } \\
\text { ditions }\end{array}$ \\
\hline $\begin{array}{l}\text { Blinding of outcome as- } \\
\text { sessment (detection bias) }\end{array}$ & Low risk & $\begin{array}{l}\text { "anaesthesiologist (a senior member of the study group) blinded to the muscle } \\
\text { relaxant and concealed in a room next to the operation theatre until } 40 \text { secs af- } \\
\text { ter its administration, hereby preventing him from seeing fasciculations after } \\
\text { succinylcholine" }\end{array}$ \\
\hline
\end{tabular}

$\begin{aligned} & \text { Incomplete outcome data } \\ & \text { (attrition bias) }\end{aligned}$ Low risk cases accounted for


Larsen 2005 (Continued)

All outcomes

Selective reporting (re- Low risk $\quad$ All outcomes reported
porting bias)

Selective reporting (re-

\section{Latorre 1996}

\begin{tabular}{ll}
\hline Methods & $\begin{array}{l}\text { RCT } \\
\text { Modified RSI } \\
\mathrm{N}=40\end{array}$ \\
\hline Participants & ASA I - III \\
& $\begin{array}{l}\text { Age } 18-62, \text { mean } 44.5 \\
\text { Mean weight } 73.5 \mathrm{~kg}\end{array}$ \\
\hline Interventions & 1. Rocuronium $0.6 \mathrm{mg} / \mathrm{kg}(\mathrm{n}=20)$ \\
& 2. Succinylcholine $1 \mathrm{mg} / \mathrm{kg}(\mathrm{n}=20)$ \\
& Sequence with: fentanyl $2-3 \mathrm{mcg} / \mathrm{kg}$, propofol $1.5-2.0 \mathrm{mg} / \mathrm{kg}$
\end{tabular}

\begin{tabular}{|c|c|}
\hline \multirow[t]{2}{*}{ Outcomes } & $\begin{array}{l}\text { 1. Intubating conditions } 60 \text { s after muscle relaxant. Reported as score based on clinical variables: laryn- } \\
\text { goscopy, vocal cord movement and coughing } \\
\text { 2. Onset time } \\
\text { 3. Clinical duration of muscle block with EMG recordings on adductor pollicis } \\
\text { 4. \% blocked at time of intubation }\end{array}$ \\
\hline & 5. Heart rate, blood pressure and arterial oxygen saturation \\
\hline
\end{tabular}

\begin{tabular}{ll}
\hline Adverse events & None reported. \\
\hline Time \& Place & Study dates not reported. \\
& University of Johannes-Gutenberg, Mainz, Germany \\
\hline
\end{tabular}

Funding and declarations Funding source: none declared

Declarations of interest: none declared

Notes In German

\section{Risk of bias}

\begin{tabular}{lll}
\hline Bias & Authors' judgement & Support for judgement \\
\hline $\begin{array}{l}\text { Random sequence genera- } \\
\text { tion (selection bias) }\end{array}$ & Unclear risk & "patients were allocated randomly" \\
\hline $\begin{array}{l}\text { Allocation concealment } \\
\text { (selection bias) }\end{array}$ & Low risk & Examiner did not know which drug was injected \\
\hline $\begin{array}{l}\text { Blinding of participants } \\
\text { and personnel (perfor- } \\
\text { mance bias) } \\
\text { All outcomes }\end{array}$ & Low risk & $\begin{array}{l}\text { Participant asleep and personnel performance does not affect intubating con- } \\
\text { ditions }\end{array}$ \\
\hline
\end{tabular}

\begin{tabular}{lll}
\hline $\begin{array}{l}\text { Blinding of outcome as- } \\
\text { sessment (detection bias) }\end{array}$ & High risk & No comment
\end{tabular}


Latorre 1996 (Continued)

All outcomes

Incomplete outcome data Low risk $\quad$ All cases accounted for
(attrition bias)

(attrition bias)

All outcomes

Selective reporting (re- Low risk $\quad$ All outcomes reported
porting bias)

porting bias)

\section{Le Corre 1999}

\begin{tabular}{ll}
\hline Methods & RCT \\
& Modified RSI \\
& $\mathrm{N}=150$ \\
\hline Participants & ASA I - II \\
& 18 - 75 years \\
& Elective OR \\
& Mean age 47.5 \\
& Mean weight $61.5 \mathrm{~kg}$ \\
\hline Interventions & 1. Rocuronium $0.6 \mathrm{mg} / \mathrm{kg}(\mathrm{n}=30)$ \\
& 2. Succinylcholine $1 \mathrm{mg} / \mathrm{kg}(\mathrm{n}=30)$ \\
& 3. Atracurium $0.5 \mathrm{mg} / \mathrm{kg}(\mathrm{n}=30)^{*}$ \\
& 4. Mivacurium $0.2 \mathrm{mg} / \mathrm{kg}(\mathrm{n}=30)^{*}$ \\
& 5. Vecuronium $0.08 \mathrm{mg} / \mathrm{kg}(\mathrm{n}=30)^{*}$ \\
& Premedication: alprazolam $0.5 \mathrm{mg} / \mathrm{kg}$ po \\
& Sequence with: fentanyl $3 \mathrm{mcg} / \mathrm{kg}, \mathrm{propofol} 2.5 \mathrm{mg} / \mathrm{kg}$
\end{tabular}

\begin{tabular}{ll}
\hline Outcomes & 1. Time to complete disappearance of response to orbicularis oculi after TOF stimulation \\
2. Intubation conditions reported as excellent, good, poor and impossible. Scale variables were vocal \\
cord movement and ease of laryngoscopy.
\end{tabular}

Adverse events None reported.

\begin{tabular}{ll}
\hline Time \& Place & Study dates not reported. Article accepted June 1999. \\
& Jean Bernard Hospital, Poitiers, France \\
\hline
\end{tabular}

Funding and declarations Funding source: none declared

Declarations of interest: none declared

Notes Efficacy analysis

\section{Risk of bias}

\begin{tabular}{lll}
\hline Bias & Authors' judgement & Support for judgement \\
\hline $\begin{array}{l}\text { Random sequence genera- } \\
\text { tion (selection bias) }\end{array}$ & Unclear risk & "random allocation" \\
\hline $\begin{array}{l}\text { Allocation concealment } \\
\text { (selection bias) }\end{array}$ & Low risk & $\begin{array}{l}\text { "intubation was performed by another physician unaware of muscle relaxant } \\
\text { injected" }\end{array}$ \\
\hline
\end{tabular}


Le Corre 1999 (Continued)

Blinding of participants and personnel (perfor-

Low risk mance bias)

All outcomes
Participant asleep and personnel performance does not affect intubating conditions

\begin{tabular}{|c|c|c|}
\hline $\begin{array}{l}\text { Blinding of outcome as- } \\
\text { sessment (detection bias) } \\
\text { All outcomes }\end{array}$ & Low risk & $\begin{array}{l}\text { "onset time of neuromuscular blockade ...was estimated by a blinded physi- } \\
\text { cian who was not involved in the intubating procedure. When the orbicularis } \\
\text { oculi was completely blocked, intubation was performed by another physician } \\
\text { " }\end{array}$ \\
\hline
\end{tabular}

Incomplete outcome data High risk (attrition bias)

All outcomes
Participants were excluded from the final analysis in 2 cases: 1 ) when the vocal cords were not completely visualized during the laryngoscopy and 2) when onset time was longer than 300s.

In participants not fully paralysed after 300 s after the administration of the muscle relaxant, intubation was performed after giving a supplemental dose of muscle relaxant

Selective reporting (re- Unclear risk due to incomplete outcome data, difficult to assess.

porting bias)

\section{Magorian 1993}

\begin{tabular}{ll}
\hline Methods & RCT \\
& Modified RSI \\
& $\mathrm{N}=50$ \\
\hline Participants & ASA I III \\
& 18 - 70 years \\
& uncertain location \\
& Mean age 36 \\
& Mean weight $68 \mathrm{~kg}$ \\
& Mallampati 1 or 2 airway and no contraindication to RSI \\
\hline
\end{tabular}

Interventions
$\begin{aligned} & \text { 1. Rocuronium } 0.6 \mathrm{mg} / \mathrm{kg}(\mathrm{n}=10) \\ & \text { 3. Rocuronium } 0.9 \mathrm{mg} / \mathrm{kg}(\mathrm{n}=10) \\ & \text { 4. Vecuronium } 1.2 \mathrm{mg} / \mathrm{kg}(\mathrm{n}=10) \\ & \text { 5. Succinylcholine } 1 \mathrm{mg} / \mathrm{kg}(\mathrm{n}=10) \\ & \text { Premedication: midazolam } 0.02-0.05 \mathrm{mg} / \mathrm{kg} \\ & \text { Sequence with: fentanyl (?dose), thiopental } 2-7 \mathrm{mg} / \mathrm{kg} \\ & \text { Outcomes }\end{aligned}$
$\begin{aligned} & \text { 1. Ablation of T1 (onset) } \\ & \text { 2. Return of T1 to } 25 \% \text { of duration } \\ & \text { 3. Intubation conditions } 60 \mathrm{~s} \text { after muscle relaxant. Reported as excellent, good, poor, inadequate } \\ & \text { based on jaw relaxation, vocal cord movement and diaphragm movement } \\ & \text { 4. Presence of fasciculations }\end{aligned}$

Adverse events None reported.

Time \& Place

Study dates not reported. Article accepted June 1993

University of California, San Franscisco, USA.

\section{Funding and declarations Funding source: none declared}


Magorian 1993 (Continued)

Declarations of interest: none declared

\begin{tabular}{|c|c|c|}
\hline Notes & Efficacy analysis & \\
\hline \multicolumn{3}{|l|}{ Risk of bias } \\
\hline Bias & Authors' judgement & Support for judgement \\
\hline $\begin{array}{l}\text { Random sequence genera- } \\
\text { tion (selection bias) }\end{array}$ & Unclear risk & "randomly designated" \\
\hline $\begin{array}{l}\text { Allocation concealment } \\
\text { (selection bias) }\end{array}$ & Low risk & $\begin{array}{l}\text { "intubation of trachea was attempted by a clinician who was blinded to the } \\
\text { muscle relaxant administered" }\end{array}$ \\
\hline $\begin{array}{l}\text { Blinding of participants } \\
\text { and personnel (perfor- } \\
\text { mance bias) } \\
\text { All outcomes }\end{array}$ & Low risk & $\begin{array}{l}\text { Participant asleep and personnel performance does not affect intubating con- } \\
\text { ditions }\end{array}$ \\
\hline $\begin{array}{l}\text { Blinding of outcome as- } \\
\text { sessment (detection bias) } \\
\text { All outcomes }\end{array}$ & High risk & $\begin{array}{l}\text { "Intubating conditions were judged by each clinician, and the presence or ab- } \\
\text { sence of fasciculations was noted" }\end{array}$ \\
\hline $\begin{array}{l}\text { Incomplete outcome data } \\
\text { (attrition bias) } \\
\text { All outcomes }\end{array}$ & Low risk & All cases reported \\
\hline $\begin{array}{l}\text { Selective reporting (re- } \\
\text { porting bias) }\end{array}$ & Low risk & All outcomes reported \\
\hline
\end{tabular}

Malik 2004

\begin{tabular}{ll}
\hline Methods & RCT \\
& Simulated RSI \\
& $\mathrm{N}=60$
\end{tabular}

\section{Funding and declarations Funding source: none declared}


Malik 2004 (Continued)

Declarations of interest: none declared

\begin{tabular}{|c|c|c|}
\hline Notes & Efficacy analysis & \\
\hline \multicolumn{3}{|l|}{ Risk of bias } \\
\hline Bias & Authors' judgement & Support for judgement \\
\hline $\begin{array}{l}\text { Random sequence genera- } \\
\text { tion (selection bias) }\end{array}$ & Unclear risk & "randomly allocated" \\
\hline $\begin{array}{l}\text { Allocation concealment } \\
\text { (selection bias) }\end{array}$ & High risk & No comment made \\
\hline $\begin{array}{l}\text { Blinding of participants } \\
\text { and personnel (perfor- } \\
\text { mance bias) } \\
\text { All outcomes }\end{array}$ & Low risk & $\begin{array}{l}\text { Participant asleep and personnel performance does not affect intubating con- } \\
\text { ditions }\end{array}$ \\
\hline $\begin{array}{l}\text { Blinding of outcome as- } \\
\text { sessment (detection bias) } \\
\text { All outcomes }\end{array}$ & High risk & No comment made \\
\hline $\begin{array}{l}\text { Incomplete outcome data } \\
\text { (attrition bias) } \\
\text { All outcomes }\end{array}$ & Low risk & All cases reported \\
\hline $\begin{array}{l}\text { Selective reporting (re- } \\
\text { porting bias) }\end{array}$ & Low risk & All outcomes reported \\
\hline
\end{tabular}

Marsch 2011

\begin{tabular}{ll}
\hline Methods & RCT \\
Simulated RSI & $\mathrm{N}=401$ \\
\hline Participants & Emergency ICU \\
& Age $\geq 18$ yrs \\
& Mean age 62 \\
& Mean weight $73 \mathrm{~kg}$ \\
\hline 1. Rocuronium $0.6 \mathrm{mg} / \mathrm{kg}(\mathrm{n}=201)$ \\
2. Succinylcholine $1 \mathrm{mg} / \mathrm{kg}(\mathrm{n}=200)$ \\
Sequence with: fentanyl $1 \mathrm{mcg} / \mathrm{kg}$, propofol $1 \mathrm{mg} / \mathrm{kg}$ or etomidate $0.2 \mathrm{mg} / \mathrm{kg}$ \\
\hline $\begin{array}{l}\text { 1. Incidence of desaturation } \geq 5 \% \text { by pulse oximetry } \\
\text { 2. Duration of intubation sequence } \\
\text { 3. Incidence of failed first intubation }\end{array}$
\end{tabular}


4. Intubation conditions after fasciculations stopped or 60 s from muscle relaxant injection. Reported as excellent, good and poor based on a score from 6 clinical variables (laryngoscopy, vocal cords position, vocal cord movement and intubation response with regard to coughing and limb movement).

\section{Haemodynamic consequences}

\begin{tabular}{ll}
\hline Adverse events & None reported \\
\hline Time \& Place & August 2006 to June 2010 \\
& University Hospital of Basel, Basel, Switzerland.
\end{tabular}

Funding and declarations Funding source: none declared

Declarations of interest: none declared

\section{Notes}

\section{Risk of bias}

\begin{tabular}{lll}
\hline Bias & Authors' judgement & Support for judgement \\
\hline $\begin{array}{l}\text { Random sequence genera- } \\
\text { tion (selection bias) }\end{array}$ & Low risk & $\begin{array}{l}\text { Stratified randomization by gender was used to ensure a similar distribution of } \\
\text { gender in both groups }\end{array}$ \\
\hline $\begin{array}{l}\text { Allocation concealment } \\
\text { (selection bias) }\end{array}$ & Low risk & $\begin{array}{l}\text { Using sealed envelopes, participants were randomly allocated by the study } \\
\text { physician }\end{array}$ \\
\hline $\begin{array}{l}\text { Blinding of participants } \\
\text { and personnel (perfor- } \\
\text { mance bias) }\end{array}$ & Low risk & $\begin{array}{l}\text { Participant asleep and personnel performance does not affect intubating con- } \\
\text { ditions }\end{array}$ \\
\hline $\begin{array}{l}\text { Blinding of outcome as- } \\
\text { sessment (detection bias) } \\
\text { All outcomes }\end{array}$ & High risk & Outcome assessor was unblinded \\
\hline $\begin{array}{l}\text { Incomplete outcome data } \\
\begin{array}{l}\text { (attrition bias) } \\
\text { All outcomes }\end{array}\end{array}$ & Low risk & All cases accounted for \\
\hline $\begin{array}{l}\text { Selective reporting (re- } \\
\text { porting bias) }\end{array}$ & Low risk & All outcomes reported \\
\hline
\end{tabular}

\section{Mazurek 1998}

\begin{tabular}{ll}
\hline Methods & RCT \\
& Simulated RSI \\
& $\mathrm{N}=26$ \\
\hline Participants & ASA I - III \\
& $2-15$ years \\
& Emergency OR \\
& Mean age 6.6 \\
& Mean weight $28 \mathrm{~kg}$ \\
\hline Interventions & 1. Rocuronium $1.2 \mathrm{mg} / \mathrm{kg}(\mathrm{n}=13)$ \\
\hline
\end{tabular}


Mazurek 1998 (Continued)

2. Succinylcholine $1.5 \mathrm{mg} / \mathrm{kg}(\mathrm{n}=13)$

Sequence with: atropine $0.01 \mathrm{mg} / \mathrm{kg}$, thiopental $5 \mathrm{mg} / \mathrm{kg}$

Outcomes $\begin{aligned} & \text { 1. Onset and quality of muscle paralysis with TOF } \\ & \text { 2. Intubation conditions } 30 \text { s after muscle relaxant. Reported excellent, good, fair and poor from a score } \\ & \text { based on jaw relaxation, vocal cords and response to tube. }\end{aligned}$
$\begin{aligned} & \text { 3. Onset of apnoea }\end{aligned}$

\begin{tabular}{ll}
\hline Adverse events & Precipitation of thiopental and rocuronium during induction in one case. \\
\hline Time \& Place & Study dates not reported. Article accepted for publication September 1998 \\
& Chicago, USA. \\
\hline Funding and declarations & Funding source: none declared \\
& Declarations of interest: none declared \\
\hline Notes & Efficacy analysis \\
\hline
\end{tabular}

\section{Risk of bias}

\begin{tabular}{|c|c|c|}
\hline Bias & Authors' judgement & Support for judgement \\
\hline $\begin{array}{l}\text { Random sequence genera- } \\
\text { tion (selection bias) }\end{array}$ & Low risk & Participants were randomized using a random numbers table \\
\hline $\begin{array}{l}\text { Allocation concealment } \\
\text { (selection bias) }\end{array}$ & Low risk & $\begin{array}{l}\text { "all investigators except the one designated to dispense the study drug were } \\
\text { blinded to choice of muscle relaxant" }\end{array}$ \\
\hline $\begin{array}{l}\text { Blinding of participants } \\
\text { and personnel (perfor- } \\
\text { mance bias) } \\
\text { All outcomes }\end{array}$ & Low risk & $\begin{array}{l}\text { Participant asleep and personnel performance does not affect intubating con- } \\
\text { ditions }\end{array}$ \\
\hline $\begin{array}{l}\text { Blinding of outcome as- } \\
\text { sessment (detection bias) } \\
\text { All outcomes }\end{array}$ & Low risk & $\begin{array}{l}\text { "The investigators performed the laryngoscopies but were blinded to the re- } \\
\text { laxant by standing with their back to the patient during the induction so that } \\
\text { they could not detect fasciculations." }\end{array}$ \\
\hline $\begin{array}{l}\text { Incomplete outcome data } \\
\text { (attrition bias) } \\
\text { All outcomes }\end{array}$ & Low risk & No missing data \\
\hline $\begin{array}{l}\text { Selective reporting (re- } \\
\text { porting bias) }\end{array}$ & Low risk & All outcomes reported \\
\hline
\end{tabular}

\section{McCourt 1998}

\begin{tabular}{ll}
\hline Methods & RCT \\
& Simulated RSI \\
& $\mathrm{N}=318$ \\
\hline Participants & ASA I - IV \\
& $18-75$ years \\
& Emergency and elective participants in OR \\
& Mean age 41.5 \\
\hline
\end{tabular}


McCourt 1998 (Continued)

Mean weight $71 \mathrm{~kg}$

$\begin{array}{ll}\text { Interventions } & \text { Rocuronium } 0.6 \mathrm{mg} / \mathrm{kg}(n=61) \\ \text { 2. Rocuronium } 1.0 \mathrm{mg} / \mathrm{kg}(n=130) \\ \text { 3. Succinylcholine } 1 \mathrm{mg} / \mathrm{kg}(\mathrm{n}=127) \\ \text { Sequence with: fentanyl } 1-2 \mathrm{mcg} / \mathrm{kg} \text {, thiopentone } 5 \mathrm{mg} / \mathrm{kg}\end{array}$

Outcomes

1. Intubation conditions 60 s after muscle relaxant. Reported as excellent, good and poor after Viby-Mogensen et al. Based on conditions for laryngoscopy, vocal cords and reaction to intubation presented in a table

\begin{tabular}{ll}
\hline Adverse events & Erythema occurred in 6 participants who received succinlycholine and 17 who received rocuronium. \\
Bronchospasm occurred once in Group 2.
\end{tabular}

Time \& Place

The Queen's University of Belfast, the Helsinki University Central Hospital UK

\section{Funding and declarations Funding source: Organon Teknika}

Declarations of interest: none declared

Notes Efficacy analysis

\section{Risk of bias}

\begin{tabular}{|c|c|c|}
\hline Bias & Authors' judgement & Support for judgement \\
\hline $\begin{array}{l}\text { Random sequence genera- } \\
\text { tion (selection bias) }\end{array}$ & Low risk & Computer-generated randomizations \\
\hline $\begin{array}{l}\text { Allocation concealment } \\
\text { (selection bias) }\end{array}$ & Low risk & Intubator unaware of drug given \\
\hline $\begin{array}{l}\text { Blinding of participants } \\
\text { and personnel (perfor- } \\
\text { mance bias) } \\
\text { All outcomes }\end{array}$ & Low risk & $\begin{array}{l}\text { Participant asleep and personnel performance does not affect intubating con- } \\
\text { ditions }\end{array}$ \\
\hline $\begin{array}{l}\text { Blinding of outcome as- } \\
\text { sessment (detection bias) } \\
\text { All outcomes }\end{array}$ & Low risk & $\begin{array}{l}\text { "intubation were carried out by an assessor, blinded to the treatment adminis- } \\
\text { tered, 50s after the end of injection of the neuro-muscular blocking drug This } \\
\text { assessor was not present in the room until about } 45 \text { s after the neuromuscular } \\
\text { blocking drug had been given." }\end{array}$ \\
\hline $\begin{array}{l}\text { Incomplete outcome data } \\
\text { (attrition bias) } \\
\text { All outcomes }\end{array}$ & Low risk & Incomplete data were accounted for and well explained \\
\hline $\begin{array}{l}\text { Selective reporting (re- } \\
\text { porting bias) }\end{array}$ & Low risk & All outcomes reported \\
\hline
\end{tabular}

Mencke 2005

\begin{tabular}{ll}
\hline Methods & RCT \\
& Simulated RSI \\
$\mathrm{N}=120$ \\
\hline
\end{tabular}


Mencke 2005 (Continued)

Participants $\quad$ ASA I- II
Adults

Mean age 49.8

Mean weight $75 \mathrm{~kg}$

Interventions Rocuronium $0.6 \mathrm{mg} / \mathrm{kg}$ ( $\mathrm{n}=30 \mathrm{men})$
2. Rocuronium $0.6 \mathrm{mg} / \mathrm{kg}(\mathrm{n}=30$ women)
3. Succinylcholine $1.0 \mathrm{mg} / \mathrm{kg}(\mathrm{n}=30 \mathrm{men})$
4. Succinylcholine $1.0 \mathrm{mg} / \mathrm{kg}$ ( $\mathrm{n}=30$ women)
Premed: midazolam $7.5 \mathrm{mg}$
Sequence with: thiopental $5 \mathrm{mg} / \mathrm{kg}$, fentanyl $3 \mathrm{mcg} / \mathrm{kg}$

Outcomes

1. Intubation conditions 60 s after muscle relaxant. Reported as excellent, good and poor based on laryngoscopy, vocal cord position and reaction to tube

2. Intubation times

\begin{tabular}{ll}
\hline Adverse events & None reported. \\
\hline Time \& Place & Study dates not reported. \\
& University of Rostock, Rostock, Germany \\
\hline
\end{tabular}

Funding and declarations Funding source: none declared

Declarations of interest: none declared

Notes In German. Data aggregated for groups $1 \& 2$ and groups $3 \& 4$

\section{Risk of bias}

\begin{tabular}{lll}
\hline Bias & Authors' judgement & Support for judgement \\
\hline $\begin{array}{l}\text { Random sequence genera- } \\
\text { tion (selection bias) }\end{array}$ & Low risk & Computerized randomization \\
\hline $\begin{array}{l}\text { Allocation concealment } \\
\text { (selection bias) }\end{array}$ & Low risk & Intubation performed by blind operator \\
\hline $\begin{array}{l}\text { Blinding of participants } \\
\text { and personnel (perfor- } \\
\text { mance bias) }\end{array}$ & Low risk & Pll outcomes \\
\hline $\begin{array}{l}\text { Blinding of outcome as- } \\
\text { sessment (detection bias) } \\
\text { All outcomes }\end{array}$ & High risk & ditions \\
\hline $\begin{array}{l}\text { Incomplete outcome data } \\
\text { (attrition bias) } \\
\text { All outcomes }\end{array}$ & Low risk & No comment \\
\hline
\end{tabular}


Mencke 2005 (Continued)

Selective reporting (re- $\quad$ Low risk $\quad$ All outcomes reported
porting bias)
porting bias)

Mencke 2006

\begin{tabular}{ll}
\hline Methods & RCT \\
& Simulated RSI \\
& $\mathrm{N}=150$ \\
\hline Participants & ASA I - II \\
& $18-77$ years \\
& Uncertain location \\
& 1. Rocuronium $0.6 \mathrm{mg} / \mathrm{kg}(\mathrm{n}=76)$ \\
Interventions & Sequecinylcholine $1.0 \mathrm{mg} / \mathrm{kg}(\mathrm{n}=74)$ \\
& Sequence with: fentanyl $3 \mathrm{mcg} / \mathrm{kg}$, thiopental $5.0 \mathrm{mg} / \mathrm{kg}$
\end{tabular}

Outcomes 1. Intubation conditions 50 s after muscle relaxant by experienced anaesthesiologist. Reported as excellent, good and poor based on laryngoscopy, vocal cord movement and position and reaction to tube insertion or cuff inflation

2. Intubation time

3. Adverse outcomes: Postoperative hoarseness, sore throat, vocal cord injuries

\begin{tabular}{|c|c|c|}
\hline Adverse events & \multicolumn{2}{|c|}{ Thoroughly reported as one of the primary outcomes. } \\
\hline Time \& Place & \multicolumn{2}{|c|}{ Study dates not reported. Article accepted September 2005.} \\
\hline & \multicolumn{2}{|c|}{ University of Rostock, Rostock, Germany } \\
\hline Funding and declarations & \multicolumn{2}{|c|}{ Funding source: none declared } \\
\hline & \multicolumn{2}{|c|}{ Declarations of interest: none declared } \\
\hline Notes & \multicolumn{2}{|l|}{ Efficacy analysis } \\
\hline \multicolumn{3}{|l|}{ Risk of bias } \\
\hline Bias & Authors' judgement & Support for judgement \\
\hline $\begin{array}{l}\text { Random sequence genera- } \\
\text { tion (selection bias) }\end{array}$ & Low risk & Random number draws \\
\hline $\begin{array}{l}\text { Allocation concealment } \\
\text { (selection bias) }\end{array}$ & Low risk & "syringes were prepared by an independent investigator" \\
\hline $\begin{array}{l}\text { Blinding of participants } \\
\text { and personnel (perfor- } \\
\text { mance bias) } \\
\text { All outcomes }\end{array}$ & Low risk & $\begin{array}{l}\text { Participant asleep and personnel performance does not affect intubating con- } \\
\text { ditions }\end{array}$ \\
\hline $\begin{array}{l}\text { Blinding of outcome as- } \\
\text { sessment (detection bias) } \\
\text { All outcomes }\end{array}$ & Low risk & $\begin{array}{l}\text { "To prevent the anesthesiologist who performed the tracheal intubation from } \\
\text { noting succinylcholine-induced muscle fasciculations, he was called to enter } \\
\text { the study room after 40s" }\end{array}$ \\
\hline
\end{tabular}


Mencke 2006 (Continued)

Incomplete outcome data Low risk No missing data
(attrition bias)

All outcomes

Selective reporting (re- Low risk $\quad$ All outcomes reported
porting bias)

porting bias)

\section{Mitra 2001}

\begin{tabular}{|c|c|}
\hline Methods & $\begin{array}{l}\text { RCT } \\
\text { Modified RSI } \\
\mathrm{N}=40\end{array}$ \\
\hline \multirow[t]{3}{*}{ Participants } & $\begin{array}{l}\text { ASA I - II } \\
\text { Adult, mean age } 40\end{array}$ \\
\hline & $\begin{array}{l}\text { Mean weight } 59.6 \mathrm{~kg} \\
\text { Elective OR }\end{array}$ \\
\hline & Mallampati 1 or 2 airways \\
\hline \multirow[t]{2}{*}{ Interventions } & $\begin{array}{l}\text { 1. Rocuronium } 0.6 \mathrm{mg} / \mathrm{kg}(\mathrm{n}=20) \\
\text { 2. Succinylcholine } 1.5 \mathrm{mg} / \mathrm{kg}(\mathrm{n}=20) \\
\text { Premedication: diazepam } 5 \mathrm{mg}\end{array}$ \\
\hline & Sequence with: morphine $1 \mathrm{mg} / \mathrm{kg}$, propofol $2.0 \mathrm{mg} / \mathrm{kg}$ \\
\hline Outcomes & $\begin{array}{l}\text { 1. Intraocular pressure } \\
\text { 2. Intubating conditions } 60 \text { s after muscle relaxant. Reported as excellent, good, poor and inadequate }\end{array}$ \\
\hline Adverse events & None reported. \\
\hline \multirow[t]{2}{*}{ Time \& Place } & Study dates not reported. \\
\hline & Government Medical College and Hospital, Chandigarh, India \\
\hline
\end{tabular}

\section{Funding and declarations Funding source: none declared}

Declarations of interest: none declared

\begin{tabular}{|c|c|c|}
\hline Notes & Efficacy analysis & \\
\hline \multicolumn{3}{|l|}{ Risk of bias } \\
\hline Bias & Authors' judgement & Support for judgement \\
\hline $\begin{array}{l}\text { Random sequence genera- } \\
\text { tion (selection bias) }\end{array}$ & Unclear risk & "randomized" \\
\hline $\begin{array}{l}\text { Allocation concealment } \\
\text { (selection bias) }\end{array}$ & Low risk & $\begin{array}{l}\text { "all drugs administered into ...infusion by one anaesthetist who was unaware } \\
\text { of drug administered" }\end{array}$ \\
\hline $\begin{array}{l}\text { Blinding of participants } \\
\text { and personnel (perfor- } \\
\text { mance bias) } \\
\text { All outcomes }\end{array}$ & Low risk & $\begin{array}{l}\text { Participant asleep and personnel performance does not affect intubating con- } \\
\text { ditions }\end{array}$ \\
\hline
\end{tabular}


Mitra 2001 (Continued)

Blinding of outcome as- Low risk "he intubating anaesthetist were not allowed to observe the injection of the sessment (detection bias) neuromuscular blocking drug or the presence of fasciculation by making them All outcomes stand with their back to the patient for $45 \mathrm{~s}$ after injection of the drug"

\begin{tabular}{lll}
$\begin{array}{l}\text { Incomplete outcome data } \\
\text { (attrition bias) }\end{array}$ & Low risk cases reported \\
$\begin{array}{l}\text { All outcomes } \\
\text { Selective reporting (re- } \\
\text { porting bias) }\end{array}$ & Low risk & All outcomes reported \\
\hline
\end{tabular}

\section{Naguib 1994}

\begin{tabular}{ll}
\hline Methods & RCT \\
& Modified RSI \\
& $N=70$
\end{tabular}

\section{Outcomes}

\section{Onset time after priming of muscle blockade with TOF}

2. Intubation conditions with different priming sequences 30 s after thiopentone dose. Reported as excellent, good or poor based on jaw relaxation, vocal cord movement and diaphragm movement.

3. Recovery of twitch height to $10 \%$ of control

\begin{tabular}{ll}
\hline Adverse events & None reported \\
\hline Time \& Place & Study dates not reported. Article accepted April 1994. \\
& King Khalid University Hospital, Riyadh, Sadui Arabia \\
\hline
\end{tabular}

Funding and declarations Funding source: none declared

Declarations of interest: none declared

Notes Efficacy analysis

\section{Risk of bias}

Bias Authors' judgement Support for judgement

\begin{tabular}{lll}
\hline Random sequence genera- & Unclear risk & "patients were randomly assigned to seven groups" \\
tion (selection bias)
\end{tabular}
tion (selection bias) 
Naguib 1994 (Continued)

Allocation concealment Low risk Tracheal intubation was performed after complete neuromuscular block by (selection bias) an experienced anaesthetist who was not involved in the study and was not aware of the muscle relaxant used

$\begin{array}{ll}\begin{array}{l}\text { Blinding of participants } \\ \text { and personnel (perfor- }\end{array} & \text { Low risk }\end{array}$

mance bias)

All outcomes

\begin{tabular}{ll}
\hline Blinding of outcome as- & Unclear risk
\end{tabular}

All outcomes

Incomplete outcome data Low risk All cases reported
(attrition bias)
All outcomes

Selective reporting (re- Low risk $\quad$ All outcomes reported
porting bias)

\section{Naguib 1997}

\begin{tabular}{|c|c|}
\hline Methods & $\begin{array}{l}\text { RCT } \\
\text { Simulated RSI } \\
\mathrm{N}=60\end{array}$ \\
\hline Participants & $\begin{array}{l}\text { ASA I } \\
3 \text { - } 10 \text { years } \\
\text { weight } 12 \text { - } 40 \mathrm{~kg} \\
\text { Elective OR } \\
\text { Mean Age } 5.0 \\
\text { Mean weight } 20.1 \mathrm{~kg}\end{array}$ \\
\hline Interventions & $\begin{array}{l}\text { 1. Succinylcholine } 1 \mathrm{mg} / \mathrm{kg}(n=10) \\
\text { 2. Mivacurium } 0.2 \mathrm{mg} / \mathrm{kg}(n=10)^{*} \\
\text { 3. Rocuronium } 0.6 \mathrm{mg} / \mathrm{kg}(\mathrm{n}=10) \\
\text { 4. Rocuronium } 0.9 \mathrm{mg} / \mathrm{kg}(\mathrm{n}=10) \\
\text { 5. Mivacurium } 0.2 \mathrm{mg} / \mathrm{kg}+\text { rocuronium } 0.3 \mathrm{mg} / \mathrm{kg}(\mathrm{n}=10)^{\star} \\
\text { 6. Mivacurium } 0.1 \mathrm{mg} / \mathrm{kg}+\text { rocuronium } 0.45 \mathrm{mg} / \mathrm{kg}(\mathrm{n}=10)^{*} \\
\text { Premedication: trimeprazine } 2 \mathrm{mg} / \mathrm{kg} \text { po } \\
\text { Sequence with: fentanyl } 2 \mathrm{mcg} / \mathrm{kg} \text {, propofol } 2 \mathrm{mg} / \mathrm{kg}\end{array}$ \\
\hline Outcomes & $\begin{array}{l}\text { 1. Intubation conditions } 60 \text { s after muscle relaxant. Reported as excellent, good and poor based on jaw } \\
\text { relaxation, vocal cord movement and diaphragm movement. } \\
\text { 2. TOF at } 60 \text { s } \\
\text { 3. Pharmacodynamic study (not used) }\end{array}$ \\
\hline Adverse events & None reported. \\
\hline Time \& Place & $\begin{array}{l}\text { Study dates not reported. Article accepted May } 1997 . \\
\text { King Khalid University Hospital, Riyadh, Sadui Arabia }\end{array}$ \\
\hline
\end{tabular}

Funding and declarations

Funding source: none declared 
Naguib 1997 (Continued)

Declarations of interest: none declared

\begin{tabular}{ll}
\hline Notes & Efficacy analysis \\
\hline
\end{tabular}

\section{Risk of bias}

\begin{tabular}{lll}
\hline Bias & Authors' judgement & Support for judgement \\
\hline $\begin{array}{l}\text { Random sequence genera- } \\
\text { tion (selection bias) }\end{array}$ & Unclear risk & "allocated randomly" \\
\hline $\begin{array}{l}\text { Allocation concealment } \\
\text { (selection bias) }\end{array}$ & Low risk & $\begin{array}{l}\text { To maintain blinding, participants who received a single neuromuscular block- } \\
\text { ing drug had a simultaneous injection of placebo. } 60 \text { s after the end of injection } \\
\text { the trachea was intubated in all participants by the same anaesthetist who } \\
\text { was unaware of the participant's grouping }\end{array}$ \\
\hline
\end{tabular}

$\begin{array}{ll}\begin{array}{l}\text { Blinding of participants } \\ \text { and personnel (perfor- }\end{array} & \text { Low risk }\end{array}$

mance bias)

All outcomes

$\begin{array}{ll}\text { Blinding of outcome as- } & \text { High risk } \quad \text { No mention of blinding muscle relaxant used } \\ \text { sessment (detection bias) }\end{array}$

All outcomes

Incomplete outcome data Low risk All cases reported
(attrition bias)
All outcomes

Selective reporting (re- Low risk $\quad$ All outcomes reported
porting bias)

porting bias)

\begin{tabular}{|c|c|}
\hline Methods & $\begin{array}{l}\text { RCT } \\
\text { Modified RSI } \\
\mathrm{N}=42\end{array}$ \\
\hline Participants & $\begin{array}{l}\text { ASA I - II } \\
25-77 \text { years } \\
\text { Elective OR } \\
\text { Mean age } 50 \\
\text { Mean weight } 73.5 \mathrm{~kg}\end{array}$ \\
\hline Interventions & $\begin{array}{l}\text { 1. Rocuronium } 0.6 \mathrm{mg} / \mathrm{kg}(\mathrm{n}=20) \\
\text { 2. Succinylcholine } 1 \mathrm{mg} / \mathrm{kg}(\mathrm{n}=22) \\
\text { Premedication: midazolam } 0.02-0.03 \mathrm{mg} / \mathrm{kg} \\
\text { Sequence with: fentanyl } 2-3 \mathrm{mcg} / \mathrm{kg} \text {, thiopental } 4 \text { - } 5 \mathrm{mg} / \mathrm{kg}\end{array}$ \\
\hline Outcomes & $\begin{array}{l}\text { 1. Onset time of neuromuscular blocker } \\
\text { 2. Intubation conditions } 60 \text { s after injection of blinded syringe. Reported as excellent, good, fair or poor } \\
\text { based on jaw relaxation, vocal cord movement and cough response }\end{array}$ \\
\hline Adverse events & None reported. \\
\hline Time \& Place & Study dates not reported. Article accepted January 1997. \\
\hline
\end{tabular}

Rocuronium versus succinylcholine for rapid sequence induction intubation (Review) 
Nelson 1997 (Continued)

The Bowman Gray School of Medicine, Winston-Salem, USA

$\begin{array}{ll}\text { Funding and declarations } & \text { Funding source: none declared } \\ & \text { Declarations of interest: none declared }\end{array}$

Notes Efficacy analysis

\section{Risk of bias}

Bias Authors' judgement Support for judgement

\begin{tabular}{|c|c|c|}
\hline $\begin{array}{l}\text { Random sequence genera- } \\
\text { tion (selection bias) }\end{array}$ & Low risk & $\begin{array}{l}\text { "Patients were randomly assigned, via computer-generated random numbers } \\
\text { table" }\end{array}$ \\
\hline $\begin{array}{l}\text { Allocation concealment } \\
\text { (selection bias) }\end{array}$ & Low risk & Used blinded syringes \\
\hline $\begin{array}{l}\text { Blinding of participants } \\
\text { and personnel (perfor- } \\
\text { mance bias) } \\
\text { All outcomes }\end{array}$ & Low risk & $\begin{array}{l}\text { Participant asleep and personnel performance does not affect intubating con- } \\
\text { ditions }\end{array}$ \\
\hline $\begin{array}{l}\text { Blinding of outcome as- } \\
\text { sessment (detection bias) } \\
\text { All outcomes }\end{array}$ & Low risk & $\begin{array}{l}\text { Laryngoscopy and intubation began } 60 \text { s after the injection of the contents of } \\
\text { the final blinded syringe by an anaesthetist unaware of the treatment group. } \\
\text { This individual was not allowed to look at or touch the participant during the } \\
\text { period of time in which fasciculations would occur, nor was he or she allowed } \\
\text { to look at the polygraph tracing }\end{array}$ \\
\hline
\end{tabular}

Incomplete outcome data Unclear risk Did not explain why 2 participants were excluded from rocuronium group
(attrition bias)

All outcomes

\begin{tabular}{ll} 
Patel 1995 & \\
\hline Methods & RCT \\
& Modified RSI \\
& $\mathrm{N}=22$ \\
\hline Participants & Uncertain ASA \\
& Adult participants \\
& Emergency OR \\
& Mean age 44.2 \\
& Mean weight $74.7 \mathrm{~kg}$ \\
\hline Interventions & 1. Rocuronium $0.6 \mathrm{mg} / \mathrm{kg}(\mathrm{n}=7)$ \\
2. Rocuronium $0.9 \mathrm{mg} / \mathrm{kg}(\mathrm{n}=8)$ \\
3. Succinylcholine $1 \mathrm{mg} / \mathrm{kg}(\mathrm{n}=7)$ \\
Sequence with: fentanyl $(? \mathrm{dose})$, thiopental (?dose)
\end{tabular}

\begin{tabular}{ll}
\hline Outcomes & $\begin{array}{l}\text { 1. Intubation conditions after visual loss of orbicularis oculi TOF or after 90s. Reported as excellent, } \\
\text { good, fair based on jaw relaxation, vocal cord position and coughing }\end{array}$
\end{tabular}

\begin{tabular}{ll}
\hline Adverse events & None reported. \\
\hline Time \& Place & Study dates not reported. \\
\hline
\end{tabular}


Patel 1995 (Continued)

MetroHealth Medical Center, Cleveland, USA

Funding and declaration

Funding source: none declared

Declarations of interest: none declared

\begin{tabular}{ll}
\hline Notes & $\begin{array}{l}\text { Efficacy analysis } \\
\text { Abstract only }\end{array}$
\end{tabular}

\section{Risk of bias}

\begin{tabular}{|c|c|c|}
\hline Bias & Authors' judgement & Support for judgement \\
\hline $\begin{array}{l}\text { Random sequence genera- } \\
\text { tion (selection bias) }\end{array}$ & Unclear risk & "randomized" \\
\hline $\begin{array}{l}\text { Allocation concealment } \\
\text { (selection bias) }\end{array}$ & Low risk & Anaesthesiologist was blinded to relaxant \\
\hline $\begin{array}{l}\text { Blinding of participants } \\
\text { and personnel (perfor- } \\
\text { mance bias) } \\
\text { All outcomes }\end{array}$ & Low risk & $\begin{array}{l}\text { Participant asleep and personnel performance does not affect intubating con- } \\
\text { ditions }\end{array}$ \\
\hline $\begin{array}{l}\text { Blinding of outcome as- } \\
\text { sessment (detection bias) } \\
\text { All outcomes }\end{array}$ & High risk & No comment on blinding effects of drugs \\
\hline $\begin{array}{l}\text { Incomplete outcome data } \\
\text { (attrition bias) } \\
\text { All outcomes }\end{array}$ & Low risk & All cases reported \\
\hline $\begin{array}{l}\text { Selective reporting (re- } \\
\text { porting bias) }\end{array}$ & Low risk & All outcomes reported \\
\hline
\end{tabular}

\section{Pühringer 1992}

\begin{tabular}{ll}
\hline Methods & RCT \\
& Modified RSI \\
& $\mathrm{N}=30$
\end{tabular}


Pühringer 1992 (Continued)

Adverse events None reported.

Time \& Place S Study dates not reported. Article accepted February 1992.

Univeristy of Innsbruck, Innsbruck, Austria

Funding and declarations Funding source: grant from Organon Teknika

Declarations of interest: none declared

\begin{tabular}{|c|c|c|}
\hline Notes & Efficacy analysis & \\
\hline \multicolumn{3}{|l|}{ Risk of bias } \\
\hline Bias & Authors' judgement & Support for judgement \\
\hline $\begin{array}{l}\text { Random sequence genera- } \\
\text { tion (selection bias) }\end{array}$ & Low risk & Randomization table \\
\hline $\begin{array}{l}\text { Allocation concealment } \\
\text { (selection bias) }\end{array}$ & Low risk & "Unaware of the muscle relaxant used" \\
\hline $\begin{array}{l}\text { Blinding of participants } \\
\text { and personnel (perfor- } \\
\text { mance bias) } \\
\text { All outcomes }\end{array}$ & Low risk & $\begin{array}{l}\text { Participant asleep and personnel performance does not affect intubating con- } \\
\text { ditions }\end{array}$ \\
\hline $\begin{array}{l}\text { Blinding of outcome as- } \\
\text { sessment (detection bias) } \\
\text { All outcomes }\end{array}$ & Low risk & $\begin{array}{l}\text { "This person was unaware of the twitch response at the time of laryngoscopy, } \\
\text { unaware of the muscle relaxant used" }\end{array}$ \\
\hline $\begin{array}{l}\text { Incomplete outcome data } \\
\text { (attrition bias) } \\
\text { All outcomes }\end{array}$ & Low risk & All cases reported \\
\hline $\begin{array}{l}\text { Selective reporting (re- } \\
\text { porting bias) }\end{array}$ & Low risk & All outcomes reported \\
\hline
\end{tabular}

Singh 2011

\begin{tabular}{ll}
\hline Methods & RCT \\
& Modified RSI \\
& $\mathrm{N}=90$ \\
\hline Participants & ASA I - II \\
& Major elective surgery in OR \\
& 20 - 60 years \\
& Mean age 38 \\
& Mean weight $53 \mathrm{~kg}$ \\
\hline Interventions & 1. Succinylcholine $1.5 \mathrm{mg} / \mathrm{kg}(\mathrm{n}=30)$
\end{tabular}


Singh 2011 (Continued)

2. Rocuronium $0.6 \mathrm{mg} / \mathrm{kg}(\mathrm{n}=30)$

3. Vecuronium $0.08 \mathrm{mg} / \mathrm{kg}(\mathrm{n}=30)^{*}$

Sequence with propofol $2-2.5 \mathrm{mg} / \mathrm{kg}$

Outcomes

1. Intubation conditions were assessed as per Cooper et al. Reported as excellent, good, fair and poor from a score of 0 - 9

2. Intubation time

\begin{tabular}{ll}
\hline Adverse events & None reported \\
\hline Time \& Place & Study dates not reported. \\
& Regional Institute of Medical Sciences, Imphal, India \\
\hline
\end{tabular}

Funding and declarations Funding source: none declared

Declarations of interest: none declared

\section{Notes}

\section{Risk of bias}

\begin{tabular}{|c|c|c|}
\hline Bias & Authors' judgement & Support for judgement \\
\hline $\begin{array}{l}\text { Random sequence genera- } \\
\text { tion (selection bias) }\end{array}$ & Low risk & "Using computer generated randomization" \\
\hline $\begin{array}{l}\text { Allocation concealment } \\
\text { (selection bias) }\end{array}$ & High risk & No comment made \\
\hline $\begin{array}{l}\text { Blinding of participants } \\
\text { and personnel (perfor- } \\
\text { mance bias) } \\
\text { All outcomes }\end{array}$ & Low risk & $\begin{array}{l}\text { Participant asleep and personnel performance does not affect intubating con- } \\
\text { ditions }\end{array}$ \\
\hline $\begin{array}{l}\text { Blinding of outcome as- } \\
\text { sessment (detection bias) } \\
\text { All outcomes }\end{array}$ & High risk & $\begin{array}{l}\text { Once the control response had been noted, the neuromuscular blocking agent } \\
\text { was injected and the endotracheal intubation was carried out by the same per- } \\
\text { son (unblinded) }\end{array}$ \\
\hline $\begin{array}{l}\text { Incomplete outcome data } \\
\text { (attrition bias) } \\
\text { All outcomes }\end{array}$ & Low risk & All cases reported \\
\hline
\end{tabular}

Selective reporting (re- Low risk All outcomes reported
porting bias)

\begin{tabular}{ll} 
Sluga 2005 & \\
\hline Methods & RCT \\
& Simulated RSI \\
& $N=180$ \\
\hline Participants & ASA I - IV \\
& 18 years or older
\end{tabular}


Sluga 2005 (Continued)

$$
\text { Emergency OR }
$$

$\begin{array}{ll}\text { Interventions } & \text { 1. Rocuronium } 0.6 \mathrm{mg} / \mathrm{kg}(\mathrm{n}=90) \\ \text { 2. Succinylcholine } 1 \mathrm{mg} / \mathrm{kg}(\mathrm{n}=90)\end{array}$

1. Intubation conditions. Reported as excellent, good and poor based on a score that was evaluated
from laryngoscopy, vocal cords and response to intubation
2. Intubation time

\begin{tabular}{ll}
\hline Adverse events & 5 failure to intubate on first attempt. Desaturations in 5 of 90 in Group 2 and 9 of 90 in Group 1. \\
\hline Time \& Place & Study dates not reported. Article accepted April 2005. \\
& Krankenhaus Thusis, Switzerland \\
\hline
\end{tabular}

Funding and declarations Funding source: none declared

Declarations of interest: none declared

\begin{tabular}{ll}
\hline Notes & ITT analysis \\
& Exact numbers for intubating conditions provided by authors \\
\hline
\end{tabular}

\section{Risk of bias}

\begin{tabular}{lll}
\hline Bias & Authors' judgement & Support for judgement \\
\hline $\begin{array}{l}\text { Random sequence genera- } \\
\text { tion (selection bias) }\end{array}$ & Low risk & Sealed envelopes \\
\hline $\begin{array}{l}\text { Allocation concealment } \\
\text { (selection bias) }\end{array}$ & Low risk & "Patients were randomly allocated (sealed envelopes)" \\
\hline $\begin{array}{l}\text { Blinding of participants } \\
\text { and personnel (perfor- } \\
\text { mance bias) }\end{array}$ & Low risk & $\begin{array}{l}\text { Participant asleep and personnel performance does not affect intubating con- } \\
\text { ditions }\end{array}$ \\
\hline $\begin{array}{l}\text { Blinding of outcome as- } \\
\text { sessment (detection bias) }\end{array}$ & High risk & $\begin{array}{l}\text { The staff anaesthesiologist was not blinded to the neuromuscular blocking } \\
\text { drug used, and the management of difficulties and complications, if any, was } \\
\text { left to his discretion }\end{array}$ \\
\hline $\begin{array}{l}\text { Incomplete outcome data } \\
\text { (attrition bias) } \\
\text { All outcomes }\end{array}$ & Low risk & Adequately described \\
\hline $\begin{array}{l}\text { Selective reporting (re- } \\
\text { porting bias) }\end{array}$ & Low risk & \begin{tabular}{l} 
All outcomes reported \\
\hline
\end{tabular}
\end{tabular}

Sorensen 2012

\begin{tabular}{ll}
\hline Methods & RCT \\
& Modified RSI \\
& $\mathrm{N}=55$ \\
\hline Participants & Elective surgery \\
\hline
\end{tabular}


Sorensen 2012 (Continued)

$$
18 \text { - } 60 \text { years }
$$

Mean age 51

Mean weight $78 \mathrm{~kg}$

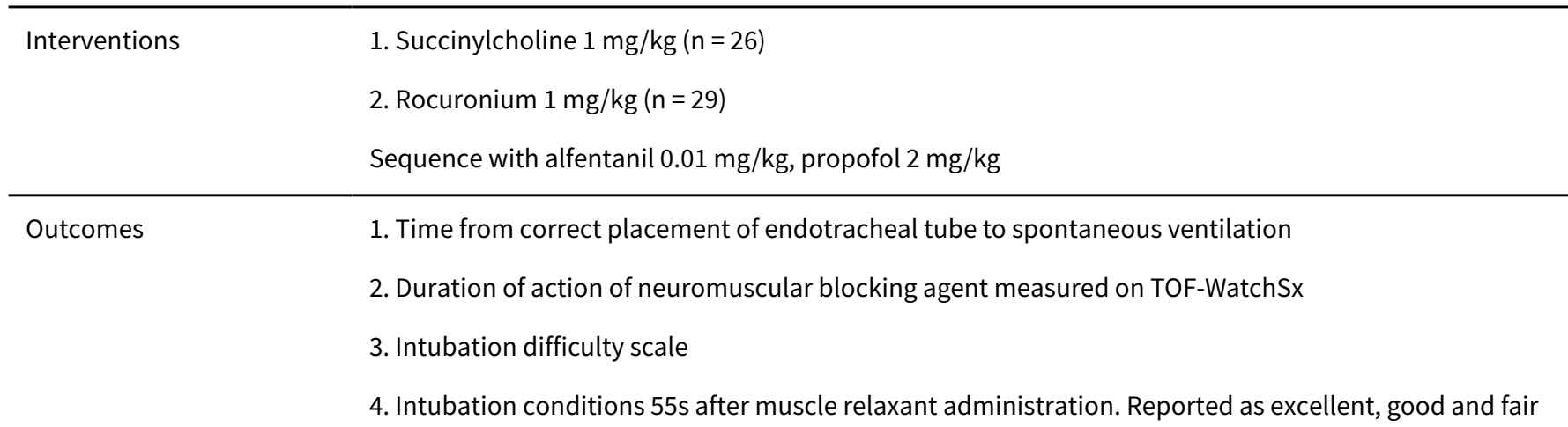

Adverse events Tachycardia above 100 beats per minute

Time \& Place Study dates not reported.

Copenhagen University Hospital, Copenhagen, Denmark

Funding and declarations Funding source: funding supported by Tryg Foundation, Lyngy Denmark

Declarations of interest: none declared

\section{Notes}

\section{Risk of bias}

\begin{tabular}{|c|c|c|}
\hline Bias & Authors' judgement & Support for judgement \\
\hline $\begin{array}{l}\text { Random sequence genera- } \\
\text { tion (selection bias) }\end{array}$ & Low risk & Computer- generated list \\
\hline $\begin{array}{l}\text { Allocation concealment } \\
\text { (selection bias) }\end{array}$ & Low risk & Opaque envelopes \\
\hline $\begin{array}{l}\text { Blinding of participants } \\
\text { and personnel (perfor- } \\
\text { mance bias) } \\
\text { All outcomes }\end{array}$ & Low risk & $\begin{array}{l}\text { Participant asleep and personnel performance does not affect intubating con- } \\
\text { ditions }\end{array}$ \\
\hline $\begin{array}{l}\text { Blinding of outcome as- } \\
\text { sessment (detection bias) } \\
\text { All outcomes }\end{array}$ & Low risk & $\begin{array}{l}\text { The investigator (in all cases, an anaesthesiology consultant) was blinded by } \\
\text { only being allowed to enter the operating theatre after correct placement of } \\
\text { the tracheal tube had been verified. The personnel doing the statistical eval- } \\
\text { uations were blinded to the allocation by being presented the allocation list } \\
\text { without the key. After statistical evaluation, an abstract and a conclusion were } \\
\text { written in } 2 \text { copies, } 1 \text { for each allocation possibility }\end{array}$ \\
\hline $\begin{array}{l}\text { Incomplete outcome data } \\
\text { (attrition bias) } \\
\text { All outcomes }\end{array}$ & Low risk & Adequate description of excluded participants \\
\hline $\begin{array}{l}\text { Selective reporting (re- } \\
\text { porting bias) }\end{array}$ & Low risk & All outcomes reported \\
\hline
\end{tabular}


Sparr 1996a

\begin{tabular}{|c|c|}
\hline Methods & $\begin{array}{l}\mathrm{RCT} \\
\text { Simulated RSI } \\
\mathrm{N}=50\end{array}$ \\
\hline Participants & $\begin{array}{l}\text { ASA I - II } \\
18-65 \text { years } \\
\text { Elective OR } \\
\text { Mean age } 31 \\
\text { Mean weight } 75.5 \mathrm{~kg}\end{array}$ \\
\hline Interventions & $\begin{array}{l}\text { 1. Rocuronium } 0.6 \mathrm{mg} / \mathrm{kg}(\mathrm{n}=25) \\
\text { 2. Succinylcholine } 1 \mathrm{mg} / \mathrm{kg}(\mathrm{n}=25) \\
\text { Sequence with: thiopentone } 6 \mathrm{mg} / \mathrm{kg}\end{array}$ \\
\hline Outcomes & $\begin{array}{l}\text { 1. Intubating conditions } 45 \text { s after administration of muscle relaxant. Reported as excellent, good, fair } \\
\text { and poor according to a scoring condition as per Cooper et al. Clinical variables include ease of laryn- } \\
\text { goscopy, aspect of vocal cords and response of diaphragm } \\
\text { 2. Presences of fasciculations } \\
\text { 3. Intubation time }\end{array}$ \\
\hline
\end{tabular}

\begin{tabular}{ll}
\hline Adverse events & One case of bronchospasm and 2 cases of ventricular ectopic beast in Group 2. One case of desatura- \\
tion in Group 1.
\end{tabular}

\begin{tabular}{ll}
\hline Time \& Place & Study dates not reported. Article accepted September 1995 \\
& University of Innsbruck, Innsbruck, Austria \\
\hline Funding and declarations & $\begin{array}{l}\text { Funding source: supported by Organon Teknika NV, Belgium. } \\
\text { Declarations of interest: none declared }\end{array}$ \\
\hline Notes & Efficacy analysis \\
\hline
\end{tabular}

\section{Risk of bias}

\begin{tabular}{|c|c|c|}
\hline Bias & Authors' judgement & Support for judgement \\
\hline $\begin{array}{l}\text { Random sequence genera- } \\
\text { tion (selection bias) }\end{array}$ & Unclear risk & Randomly allocated \\
\hline $\begin{array}{l}\text { Allocation concealment } \\
\text { (selection bias) }\end{array}$ & Low risk & "The intubator was blinded to the muscle relaxant administered" \\
\hline $\begin{array}{l}\text { Blinding of participants } \\
\text { and personnel (perfor- } \\
\text { mance bias) } \\
\text { All outcomes }\end{array}$ & Low risk & $\begin{array}{l}\text { Participant asleep and personnel performance does not affect intubating con- } \\
\text { ditions }\end{array}$ \\
\hline $\begin{array}{l}\text { Blinding of outcome as- } \\
\text { sessment (detection bias) } \\
\text { All outcomes }\end{array}$ & High risk & $\begin{array}{l}\text { " Forty seconds after the administration of the muscle relaxant, the intubator } \\
\text { was called to enter the study room...The occurrence of muscle fasciculations } \\
\text { or body movements was noted by both the intubator and the anaesthetist" }\end{array}$ \\
\hline $\begin{array}{l}\text { Incomplete outcome data } \\
\text { (attrition bias) } \\
\text { All outcomes }\end{array}$ & Low risk & Accounted for excluded participants \\
\hline
\end{tabular}


Sparr 1996a (Continued)

Selective reporting (re- Low risk $\quad$ All outcomes reported
porting bias)
porting bias)

Sparr 1996b

\begin{tabular}{ll}
\hline Methods & RCT \\
& Simulated RSI \\
& $\mathrm{N}=150$
\end{tabular}

Outcomes $\begin{aligned} & \text { 1. Intubating conditions } 45 \mathrm{~s} \text { after muscle relaxant administration. Reported as per Cooper et al as ex- } \\ & \text { cellent, good, fair and poor based on scores evaluating jaw relaxation, vocal cords and response to in- } \\ & \text { tubation } \\ & \text { 2. Intubating time } \\ & \text { 3. Fasciculations }\end{aligned}$

Adverse events Nonre reported

Time \& Place Study dates not reported. Article accepted April 1996

University of Innsbruck, Innsbruck, Austria

Funding and declarations Funding source: supported by Oganon GmbH, Division of Organon Teknika, Vienna, Austria

Declarations of interest: none declared

\begin{tabular}{|c|c|c|}
\hline Notes & Efficacy analysis & \\
\hline \multicolumn{3}{|l|}{ Risk of bias } \\
\hline Bias & Authors' judgement & Support for judgement \\
\hline $\begin{array}{l}\text { Random sequence genera- } \\
\text { tion (selection bias) }\end{array}$ & Unclear risk & "allocated randomly" \\
\hline $\begin{array}{l}\text { Allocation concealment } \\
\text { (selection bias) }\end{array}$ & Low risk & "Intubator was blinded to the treatment each patient received" \\
\hline $\begin{array}{l}\text { Blinding of participants } \\
\text { and personnel (perfor- } \\
\text { mance bias) } \\
\text { All outcomes }\end{array}$ & Low risk & $\begin{array}{l}\text { Participant asleep and personnel performance does not affect intubating con- } \\
\text { ditions. }\end{array}$ \\
\hline
\end{tabular}


Sparr 1996b (Continued)

$\begin{array}{ll}\begin{array}{l}\text { Blinding of outcome as- } \\ \text { sessment (detection bias) }\end{array} \quad \text { Low risk } & \text { "In order to prevent the intubator from noting .... muscle fasciculations.... } \\ \text { called to enter the study room 40s after the administration of the blocker" }\end{array}$

All outcomes

\begin{tabular}{lll}
\hline $\begin{array}{l}\text { Incomplete outcome data } \\
\text { (attrition bias) }\end{array}$ & Low risk & All cases accounted for \\
All outcomes & \\
\hline $\begin{array}{l}\text { Selective reporting (re- } \\
\text { porting bias) }\end{array}$ & Low risk & All outcomes reported \\
\hline
\end{tabular}

\section{Stevens 1996}

\begin{tabular}{ll}
\hline Methods & Modified RCT \\
N RSI \\
N $=70$
\end{tabular}

\begin{tabular}{ll}
\hline Participants & ASA I - II \\
& $18-65$ years \\
& Elective OR \\
& Mean age 37.6 \\
& Mean weight $73.9 \mathrm{~kg}$
\end{tabular}

Interventions Rocuronium $0.6 \mathrm{mg} / \mathrm{kg}(\mathrm{n}=30)$
2. Succinylcholine $1 \mathrm{mg} / \mathrm{kg}(\mathrm{n}=10)$
3. Mivacurium $0.15 \mathrm{mg} / \mathrm{kg}$ and rocuronium $0.6 \mathrm{mg} / \mathrm{kg}(\mathrm{n}=30)^{*}$
Premedication: midazolam $0.02-0.05 \mathrm{mg} / \mathrm{kg} \mathrm{iv}$
Sequence with: fentanyl $3 \mathrm{mcg} / \mathrm{kg}$, thiopental up to $7 \mathrm{mg} / \mathrm{kg}$

$\begin{array}{ll}\text { Outcomes } & \text { 1. Onset time of neuromuscular blocker } \\ \text { 2. Duration of neuromuscular blocker } \\ \text { 3. Intubation conditions }\end{array}$

\begin{tabular}{ll}
\hline Adverse events & None reported. \\
\hline Time \& Place & Study dates not reported. Article accepted November 1995. \\
& University of Texas Health Science Center, Texas, USA \\
\hline
\end{tabular}

Funding and declarations Funding source: none declared

Declarations of interest: none declared

\begin{tabular}{lll}
\hline Notes & Efficacy analysis & \\
\hline Risk of bias & \\
\hline Bias & Authors' judgement & Support for judgement \\
\hline $\begin{array}{l}\text { Random sequence genera- } \\
\text { tion (selection bias) }\end{array}$ & Low risk & Envelopes \\
\hline
\end{tabular}


Stevens 1996 (Continued)

$\begin{aligned} & \text { Allocation concealment } \quad \text { Low risk } \\ & \text { (selection bias) }\end{aligned}$
the three groups".

Blinding of participants Low risk
and personnel (performance bias)

All outcomes

Blinding of outcome as-
sessment (detection bias)

(dection bias)

All outcomes

\begin{tabular}{lll}
\hline $\begin{array}{l}\text { Incomplete outcome data } \\
\text { (attrition bias) }\end{array}$ & Low risk & \\
$\begin{array}{l}\text { All outcomes } \\
\text { Selective reporting (re- }\end{array}$ & Low risk & All outcomes reported \\
porting bias) & & \\
\hline
\end{tabular}

\section{Stoddart 1998}

\begin{tabular}{|c|c|}
\hline Methods & $\begin{array}{l}\text { RCT } \\
\text { Modified RSI } \\
\mathrm{N}=60\end{array}$ \\
\hline Participants & $\begin{array}{l}\text { Uncertain ASA } \\
3 \text { - } 15 \text { years } \\
\text { Elective OR for tonsillectomy } \\
\text { Mean Age } 7.5 \\
\text { Mean weight } 26.9 \mathrm{~kg}\end{array}$ \\
\hline Interventions & $\begin{array}{l}\text { 1. Rocuronium } 0.6 \mathrm{mg} / \mathrm{kg}(\mathrm{n}=30) \\
\text { 2. Succinylcholine } 1 \mathrm{mg} / \mathrm{kg}(\mathrm{n}=30) \\
\text { Premedication: paracetamol } 20 \mathrm{mg} / \mathrm{kg} \text { po } \\
\text { Sequence with: propofol } 3-4 \mathrm{mg} / \mathrm{kg}\end{array}$ \\
\hline Outcomes & $\begin{array}{l}\text { 1. Intubation conditions } 1 \text { min after muscle relaxant. Reported as excellent, good, fair or poor based on } \\
\text { scores evaluating jaw relaxation, vocal cords and response to intubation } \\
\text { 2. Duration of neuromuscular blocker } \\
\text { 3. Onset time of neuromuscular blocker }\end{array}$ \\
\hline Adverse events & None reported. \\
\hline Time \& Place & $\begin{array}{l}\text { Study dates not reported. } \\
\text { Bristol Hospital for Sick Children, Bristol, UK }\end{array}$ \\
\hline Funding and declarations & $\begin{array}{l}\text { Funding source: rocuronium and TOF guard device was provided by Organon Teknika Ltd, Cambridge } \\
\text { UK. } \\
\text { Declarations of interest: none declared }\end{array}$ \\
\hline Notes & Efficacy analysis \\
\hline
\end{tabular}


Stoddart 1998 (Continued)

Risk of bias

\begin{tabular}{lll}
\hline Bias & Authors' judgement & Support for judgement \\
\hline $\begin{array}{l}\text { Random sequence genera- } \\
\text { tion (selection bias) }\end{array}$ & Low risk & Sealed envelopes \\
\hline $\begin{array}{l}\text { Allocation concealment } \\
\text { (selection bias) }\end{array}$ & Low risk & Sealed envelopes \\
\hline $\begin{array}{l}\text { Blinding of participants } \\
\text { and personnel (perfor- } \\
\text { mance bias) }\end{array}$ & Low risk & Participant asleep and personnel performance does not affect intubating con- \\
All outcomes & ditions \\
\hline $\begin{array}{l}\text { Blinding of outcome as- } \\
\text { sessment (detection bias) }\end{array}$ & High risk & Bll outcomes \\
\hline $\begin{array}{l}\text { Incomplete outcome data } \\
\text { (attrition bias) } \\
\text { All outcomes }\end{array}$ & Low risk & All cases reported \\
\hline $\begin{array}{l}\text { Selective reporting (re- } \\
\text { porting bias) }\end{array}$ & Low risk & \\
\hline
\end{tabular}

Tang 1996

\begin{tabular}{|c|c|}
\hline Methods & $\begin{array}{l}\text { RCT } \\
\text { Modified RSI } \\
\mathrm{N}=100\end{array}$ \\
\hline Participants & $\begin{array}{l}\text { Uncertain ASA } \\
\text { All women getting elective laparoscopic surgery } \\
\text { Mean Age } 29.4 \\
\text { Mean weight } 70.0 \mathrm{~kg}\end{array}$ \\
\hline Interventions & $\begin{array}{l}\text { 1. Succinylcholine } 1 \mathrm{mg} / \mathrm{kg}+\text { rocuronium boluses }(\mathrm{n}=23) \\
\text { 2. Succinylcholine } 1 \mathrm{mg} / \mathrm{kg}+\text { mivacurium boluses }(\mathrm{n}=25) \\
\text { 3. Mivacurium } 0.2 \mathrm{mg} / \mathrm{kg}(\mathrm{n}=25)^{\star} \\
\text { 4. Rocuronium } 0.6 \mathrm{mg} / \mathrm{kg}(\mathrm{n}=27) \\
\text { Sequence with: fentanyl } 1.5 \mathrm{mcg} / \mathrm{kg} \text {, thiopental } 4 \mathrm{mg} / \mathrm{kg} \\
\text { Premedication: midazolam } 2 \mathrm{mg} \text { iv }\end{array}$ \\
\hline Outcomes & $\begin{array}{l}\text { 1. Intubating conditions } 90 \text { s after dose of muscle relaxant. Reported using a 3-point scale: excellent, } \\
\text { good and poor based on jaw relaxation and movement of vocal cords } \\
\text { 2. Neuromuscular effects }\end{array}$ \\
\hline Adverse events & $\begin{array}{l}1 \text { in Group } 1 \text { and } 6 \text { in Group } 4 \text { had upper body erythema not requiring treatment. 16\% in Group 1+ } 2 \text { de- } \\
\text { veloped postoperative myalgias. }\end{array}$ \\
\hline Time \& Place & $\begin{array}{l}\text { Study dates not reported. Article accepted January } 1996 . \\
\text { University of Texas Southwestern Medical Center, Dallas, USA }\end{array}$ \\
\hline
\end{tabular}


Tang 1996 (Continued)

Funding and declarations Funding source: none declared

Declarations of interest: none declared

Notes Efficacy analysis

\section{Risk of bias}

\begin{tabular}{|c|c|c|}
\hline Bias & Authors' judgement & Support for judgement \\
\hline $\begin{array}{l}\text { Random sequence genera- } \\
\text { tion (selection bias) }\end{array}$ & Unclear risk & "randomly assigned" \\
\hline $\begin{array}{l}\text { Allocation concealment } \\
\text { (selection bias) }\end{array}$ & High risk & No comment made \\
\hline $\begin{array}{l}\text { Blinding of participants } \\
\text { and personnel (perfor- } \\
\text { mance bias) } \\
\text { All outcomes }\end{array}$ & Low risk & $\begin{array}{l}\text { Participant asleep and personnel performance does not affect intubating con- } \\
\text { ditions }\end{array}$ \\
\hline $\begin{array}{l}\text { Blinding of outcome as- } \\
\text { sessment (detection bias) } \\
\text { All outcomes }\end{array}$ & Low risk & $\begin{array}{l}\text { "laryngoscopy was performed by an anesthesiologist who was unaware of the } \\
\text { twitch response" }\end{array}$ \\
\hline $\begin{array}{l}\text { Incomplete outcome data } \\
\text { (attrition bias) } \\
\text { All outcomes }\end{array}$ & Low risk & Complete data \\
\hline $\begin{array}{l}\text { Selective reporting (re- } \\
\text { porting bias) }\end{array}$ & Low risk & All outcomes reported \\
\hline
\end{tabular}

Tripathi 2010

\begin{tabular}{|c|c|}
\hline Methods & $\begin{array}{l}\text { RCT } \\
\text { Modified RSI } \\
\mathrm{N}=100\end{array}$ \\
\hline Participants & $\begin{array}{l}\text { ASA I - II } \\
\text { Elective OR } \\
20-60 \text { yrs } \\
\text { Mean age } 37 \\
\text { Mean weight } 51 \mathrm{~kg}\end{array}$ \\
\hline Interventions & $\begin{array}{l}\text { 1. Rocuronium } 0.9 \mathrm{mg} / \mathrm{kg}(\mathrm{n}=50) \\
\text { 2. Succinylcholine } 1.5 \mathrm{mg} / \mathrm{kg}(\mathrm{n}=50) \\
\text { Premedication: glycopyrrolate } 0.004 \mathrm{mg} / \mathrm{kg} \text { iv, ranitidine } 50 \mathrm{mg} \text { iv, tramadol } 1 \mathrm{mg} / \mathrm{kg} \text { iv, midazolam } \\
0.015 \mathrm{mg} / \mathrm{kg} \text { iv } \\
\text { Sequence with thiopental }\end{array}$ \\
\hline
\end{tabular}


Tripathi 2010 (Continued)
Outcomes
1. Onset time of neuromuscular blockade
2. Intubation conditions reported as excellent, good, fair and poor. Scores were based on jaw relax- ation, vocal cord motion and response to intubation
3. Haemodynamics
4. Complications at time of intubation \begin{tabular}{ll}
\hline Adverse events & Both groups demonstrated an increase in blood pressure, heart rate, arrhythmias and laryngospasm. \\
No significant difference between the two groups.
\end{tabular}

Time \& Place Study dates not reported.

Government Medical College, Bhavnagar, Gujarat, India

\section{Funding and declarations Funding source: none declared}

Declarations of interest: none declared

\section{Notes}

\section{Risk of bias}

\begin{tabular}{|c|c|c|}
\hline Bias & Authors' judgement & Support for judgement \\
\hline $\begin{array}{l}\text { Random sequence genera- } \\
\text { tion (selection bias) }\end{array}$ & Unclear risk & "sealed envelope" \\
\hline $\begin{array}{l}\text { Allocation concealment } \\
\text { (selection bias) }\end{array}$ & Low risk & "opening sealed envelope" \\
\hline $\begin{array}{l}\text { Blinding of participants } \\
\text { and personnel (perfor- } \\
\text { mance bias) } \\
\text { All outcomes }\end{array}$ & Low risk & $\begin{array}{l}\text { Participant asleep and personnel performance does not affect intubating con- } \\
\text { ditions }\end{array}$ \\
\hline $\begin{array}{l}\text { Blinding of outcome as- } \\
\text { sessment (detection bias) } \\
\text { All outcomes }\end{array}$ & High risk & No mention of blinding to fasciculations \\
\hline $\begin{array}{l}\text { Incomplete outcome data } \\
\text { (attrition bias) } \\
\text { All outcomes }\end{array}$ & Low risk & Complete data \\
\hline $\begin{array}{l}\text { Selective reporting (re- } \\
\text { porting bias) }\end{array}$ & Low risk & All outcomes reported \\
\hline
\end{tabular}

\section{Tryba 1994}

\begin{tabular}{ll}
\hline Methods & RCT \\
& Simulated RSI \\
& $\mathrm{N}=80$ \\
\hline Participants & ASA I- III \\
& $\begin{array}{l}\text { Adult participants } \\
\text { Elective OR }\end{array}$
\end{tabular}


Tryba 1994 (Continued)

Mean age 31.7

Mean weight $74.5 \mathrm{~kg}$

Interventions
2. Rocuronium $0.6 \mathrm{mg} / \mathrm{kg}$ prior to induction agent $(\mathrm{n}=20)$
3. Rocuronium $0.6 \mathrm{mg} / \mathrm{kg}$ following induction agent $($ true $\mathrm{RSI})(\mathrm{n}=20)$
4. Succinylcholine $1.5 \mathrm{mg} / \mathrm{kg}$ (with rocuronium primer $0.04 \mathrm{mg} / \mathrm{kg})(\mathrm{n}=20)$
Premedication: lormethazepam $2-3 \mathrm{mg}$ po and clorazepate $0.4 \mathrm{mg} / \mathrm{kg}$ po
Sequence with: fentanyl $2 \mathrm{mcg} / \mathrm{kg}$, thiopental $6 \mathrm{mg} / \mathrm{kg}$

\begin{tabular}{ll}
\hline Outcomes & $\begin{array}{l}\text { 1. Intubating conditions 30s after 3rd dose of muscle relaxant. Reported as scores according to scoring } \\
\text { system of Damaoal et al and modified by Krieg et al. Factors evaluated include laryngoscopy, severity } \\
\text { of coughing and movement of vocal cords }\end{array}$ \\
\hline Adverse events & 1 case of severe coughing in Group 1 and 5 in Group 2. \\
\hline Time \& Place & Study dates not reported. \\
& University Hospital Bergmannsheil, Bochum, Germany \\
\hline
\end{tabular}

Funding and declarations Funding source: none declared

Declarations of interest: none declared

Notes ITT analysis

\section{Risk of bias}

\begin{tabular}{|c|c|c|}
\hline Bias & Authors' judgement & Support for judgement \\
\hline $\begin{array}{l}\text { Random sequence genera- } \\
\text { tion (selection bias) }\end{array}$ & Unclear risk & "Prospective randomized double blind" \\
\hline $\begin{array}{l}\text { Allocation concealment } \\
\text { (selection bias) }\end{array}$ & Low risk & "The investigator preparing the syringes was not involved with the induction" \\
\hline $\begin{array}{l}\text { Blinding of participants } \\
\text { and personnel (perfor- } \\
\text { mance bias) } \\
\text { All outcomes }\end{array}$ & Low risk & $\begin{array}{l}\text { Participant asleep and personnel performance does not affect intubating con- } \\
\text { ditions }\end{array}$ \\
\hline $\begin{array}{l}\text { Blinding of outcome as- } \\
\text { sessment (detection bias) } \\
\text { All outcomes }\end{array}$ & High risk & No blinding of fasciculations \\
\hline $\begin{array}{l}\text { Incomplete outcome data } \\
\text { (attrition bias) } \\
\text { All outcomes }\end{array}$ & Low risk & Complete data \\
\hline $\begin{array}{l}\text { Selective reporting (re- } \\
\text { porting bias) }\end{array}$ & Low risk & All outcomes reported \\
\hline
\end{tabular}

Turan 1999

\begin{tabular}{ll}
\hline Methods & RCT \\
& Modified RSI
\end{tabular}


Turan 1999 (Continued)

$$
N=40
$$

$\begin{array}{ll}\text { Participants } & \text { Uncertain ASA } \\ & \text { Adult participants } \\ \text { Uncertain type of OR } \\ \text { Mean age } 36.3 \text { years } \\ \text { Mean weight } 74.5 \mathrm{~kg}\end{array}$

\begin{tabular}{ll}
\hline Interventions & 1. Rocuronium $1.2 \mathrm{mg} / \mathrm{kg}(\mathrm{n}=20)$ \\
& 2. Succinylcholine $1.0 \mathrm{mg} / \mathrm{kg}(\mathrm{n}=20)$ \\
& Sequence with: thiopentone $6 \mathrm{mg} / \mathrm{kg}$
\end{tabular}

$\begin{array}{ll}\text { Outcomes } & \text { 1. Intubation conditions 45s after muscle relaxant reported as excellent, good, poor and inadequate. } \\ \text { Evaluated based on Magorian et all and Dubois et all based on jaw relaxation, vocal cords and di- } \\ \text { aphragm movement } \\ \text { 2. SBP }\end{array}$

\begin{tabular}{ll}
\hline Adverse events & None reported \\
\hline Time \& Place & Study dates not reported. \\
& Turkey \\
\hline Funding and declarations & Funding source: none declared \\
& Declarations of interest: none declared \\
\hline Notes & ITT analysis \\
\hline
\end{tabular}

\section{Risk of bias}

Bias Authors'judgement Support for judgement

Random sequence genera- Unclear risk $\quad$ "divided into two groups randomly"
tion (selection bias)

tion (selection bias)

\begin{tabular}{|c|c|c|}
\hline $\begin{array}{l}\text { Allocation concealment } \\
\text { (selection bias) }\end{array}$ & High risk & No comment \\
\hline $\begin{array}{l}\text { Blinding of participants } \\
\text { and personnel (perfor- } \\
\text { mance bias) } \\
\text { All outcomes }\end{array}$ & Low risk & $\begin{array}{l}\text { Participant asleep and personnel performance does not affect intubating con- } \\
\text { ditions }\end{array}$ \\
\hline $\begin{array}{l}\text { Blinding of outcome as- } \\
\text { sessment (detection bias) } \\
\text { All outcomes }\end{array}$ & Unclear risk & No comment \\
\hline $\begin{array}{l}\text { Incomplete outcome data } \\
\text { (attrition bias) } \\
\text { All outcomes }\end{array}$ & Low risk & No missing data \\
\hline $\begin{array}{l}\text { Selective reporting (re- } \\
\text { porting bias) }\end{array}$ & Low risk & All outcomes reported \\
\hline
\end{tabular}


Türkmen 2004

\begin{tabular}{ll}
\hline Methods & RCT \\
Modified RSI \\
Adult elective surgery \\
$\mathrm{N}=60$ \\
\hline
\end{tabular}

\begin{tabular}{ll}
\hline Participants & ASA I - II \\
& Age $19-73$ years \\
(Baseline demographics table unavailable) & 1. Mivacurium $0.25 \mathrm{mg} / \mathrm{kg}(\mathrm{n}=20)^{\star}$ \\
\hline 2. Rocuronium $0.6 \mathrm{mg} / \mathrm{kg}(\mathrm{n}=20)$ \\
3. Succinylcholine $1 \mathrm{mg} / \mathrm{kg}(\mathrm{n}=20)$ \\
Premedication: Midazolam $10 \mathrm{mg}$ im \\
Sequence with: fentanyl $2 \mathrm{mg} / \mathrm{kg}$, propofol $2 \mathrm{mg} / \mathrm{kg}$
\end{tabular}

Outcomes 1. Intubation conditions after full relaxation as measured by TOF monitoring. Reported as excellent, good and bad

2. Haemodaynamics

Adverse events None reported.

Time \& Place Study dates not reported.

Istanbul Hospital, Istanbul, Turkey

Funding and declarations Funding source: none declared

Declarations of interest: none declared

\begin{tabular}{ll}
\hline Notes & In Turksih \\
& Only data for excellent intubation conditions were available (paper missing tables)
\end{tabular}

\section{Risk of bias}

\begin{tabular}{|c|c|c|}
\hline Bias & Authors' judgement & Support for judgement \\
\hline $\begin{array}{l}\text { Random sequence genera- } \\
\text { tion (selection bias) }\end{array}$ & Unclear risk & "randomized'" \\
\hline $\begin{array}{l}\text { Allocation concealment } \\
\text { (selection bias) }\end{array}$ & Low risk & $\begin{array}{l}\text { "intubation was performed by an anesthesiologist who do not know muscle } \\
\text { relaxant used" }\end{array}$ \\
\hline $\begin{array}{l}\text { Blinding of participants } \\
\text { and personnel (perfor- } \\
\text { mance bias) } \\
\text { All outcomes }\end{array}$ & Low risk & $\begin{array}{l}\text { Participant asleep and personnel performance does not affect intubating con- } \\
\text { ditions }\end{array}$ \\
\hline
\end{tabular}

$\begin{array}{lll}\begin{array}{l}\text { Blinding of outcome as- } \\ \text { sessment (detection bias) }\end{array} & \text { High risk } & \text { No comment made }\end{array}$


Türkmen 2004 (Continued)

All outcomes

Incomplete outcome data $\quad$ Unclear risk
(attrition bias)

All outcomes

Vinik 1999

\begin{tabular}{|c|c|}
\hline Methods & $\begin{array}{l}\text { RCT } \\
\text { Modified RSI } \\
\mathrm{N}=45\end{array}$ \\
\hline Participants & $\begin{array}{l}\text { ASA I - III } \\
18 \text { - } 65 \text { years } \\
\text { Elective OR for eye surgery } \\
\text { Mean age } 41.4 \\
\text { Mean weight } 74.5 \mathrm{~kg}\end{array}$ \\
\hline Interventions & $\begin{array}{l}\text { 1. Rocuronium } 0.6 \mathrm{mg} / \mathrm{kg}(\mathrm{n}=15) \\
\text { 2. Succinylcholine } 1-1.5 \mathrm{mg} / \mathrm{kg}(\mathrm{n}=15) \\
\text { 3. Atracurium } 0.5 \mathrm{mg} / \mathrm{kg}(\mathrm{n}=15)^{\star} \\
\text { Sequence with: alfentanyl } 0.025 \mathrm{mg} / \mathrm{kg} \text {, propofol } 1.5 \mathrm{mg} / \mathrm{kg} \text {, midazolam } 0.025 \mathrm{mg} / \mathrm{kg}\end{array}$ \\
\hline Outcomes & $\begin{array}{l}\text { 1. Intraocular pressure } \\
\text { 2. Intubating conditions } 60 \mathrm{~s} \text { after muscle relaxant administration. Reported as excellent, good, poor } \\
\text { and inadequate based on jaw relaxation, vocal cord movement and diaphragm movement }\end{array}$ \\
\hline
\end{tabular}

\section{Adverse events}

Time \& Place
None reported.

Study dates not reported. Article accepted December 1998

Eye Foundation Hospital, Birmingham, USA

Declarations of interest: none declared

\begin{tabular}{|c|c|c|}
\hline Notes & Efficacy analysis & \\
\hline \multicolumn{3}{|l|}{ Risk of bias } \\
\hline Bias & Authors' judgement & Support for judgement \\
\hline $\begin{array}{l}\text { Random sequence genera- } \\
\text { tion (selection bias) }\end{array}$ & Unclear risk & "Randomized" \\
\hline $\begin{array}{l}\text { Allocation concealment } \\
\text { (selection bias) }\end{array}$ & High risk & "Open-label" \\
\hline $\begin{array}{l}\text { Blinding of participants } \\
\text { and personnel (perfor- } \\
\text { mance bias) } \\
\text { All outcomes }\end{array}$ & Low risk & $\begin{array}{l}\text { Participant asleep and personnel performance does not affect intubating con- } \\
\text { ditions }\end{array}$ \\
\hline
\end{tabular}

Blinding of outcome as-

High risk

No attempt at blinding made

sessment (detection bias) 
Vinik 1999 (Continued)

All outcomes

Incomplete outcome data Low risk No missing data
(attrition bias)

(attrition bias)

All outcomes

Selective reporting (re- Low risk All outcomes reported

porting bias)

Weiss 1997

\begin{tabular}{ll}
\hline Methods & RCT \\
& Simulated RSI \\
& $\mathrm{N}=45$ \\
\hline Participants & ASA I- II \\
& $18-65$ years \\
& Elective OR \\
& Mean age 36.7 \\
& Mean weight $73.2 \mathrm{~kg}$ \\
\hline
\end{tabular}

\begin{tabular}{ll}
\hline Interventions & 1. Rocuronium $0.7 \mathrm{mg} / \mathrm{kg}(\mathrm{n}=15)$ \\
2. Rocuronium $0.9 \mathrm{mg} / \mathrm{kg}(\mathrm{n}=16)$ \\
3. Succinylcholine $1.5 \mathrm{mg} / \mathrm{kg}(\mathrm{n}=14)$ \\
Sequence with: fentanyl $2 \mathrm{mcg} / \mathrm{kg}$, thiopental $4-5 \mathrm{mg} / \mathrm{kg}$
\end{tabular}

Outcomes 1. Intubating conditions $60 \mathrm{~s}$ after muscle relaxation. Reported as excellent, good, poor or impossible based on ease of laryngoscopy, vocal cords and response to intubation

\begin{tabular}{ll}
\hline Adverse events & None reported. \\
\hline Time \& Place & Study dates not reported. Accepted March 1997. \\
& Robert Wood Johnson Medical School at Camden, Camden, USA \\
\hline Funding and declarations & Funding source: none declared \\
& Declarations of interest: none declared \\
\hline Notes & Efficacy analysis \\
\hline
\end{tabular}

\section{Risk of bias}

\begin{tabular}{lll}
\hline Bias & Authors' judgement & Support for judgement \\
\hline $\begin{array}{l}\text { Random sequence genera- } \\
\text { tion (selection bias) }\end{array}$ & Low risk & $\begin{array}{l}\text { "patients were randomly assigned, via computer-generated random numbers } \\
\text { table" }\end{array}$ \\
\hline $\begin{array}{l}\text { Allocation concealment } \\
\text { (selection bias) }\end{array}$ & Low risk & $\begin{array}{l}\text { "Both the patient and the anesthesiologist intubating the patient were blinded } \\
\text { to the muscle relaxant used" }\end{array}$ \\
\hline $\begin{array}{l}\text { Blinding of participants } \\
\text { and personnel (perfor- } \\
\text { mance bias) }\end{array}$ & Low risk & $\begin{array}{l}\text { Participant asleep and personnel performance does not affect intubating con- } \\
\text { ditions }\end{array}$ \\
\hline
\end{tabular}


Weiss 1997 (Continued)

Blinding of outcome as- Low risk "anesthesiologist performing the intubation was out of the OR during the insessment (detection bias) duction to avoid witnessing the fasciculations from succinylcholine."

All outcomes

\begin{tabular}{lll}
$\begin{array}{l}\text { Incomplete outcome data } \\
\text { (attrition bias) } \\
\text { All outcomes }\end{array}$ & Low risk & No missing data \\
\hline $\begin{array}{l}\text { Selective reporting (re- } \\
\text { porting bias) }\end{array}$ & Low risk & All outcomes reported \\
\hline
\end{tabular}

\section{Yorukoglu 2003}

\begin{tabular}{ll}
\hline Methods & RCT \\
& Modified RSI \\
& $\mathrm{N}=125$ \\
\hline Participants & ASA I-II \\
& Adult \\
elective OR & \\
& Excluded expected difficult intubations \\
\hline
\end{tabular}

Interventions $\begin{aligned} & \text { 1. Succinylcholine } 1 \mathrm{mg} / \mathrm{kg} \text { intubated } 60 \mathrm{~s}(\mathrm{n}=25) \\ & \text { 2. Rocuronium } 0.6 \mathrm{mg} / \mathrm{kg} \text { intubated } 60 \mathrm{~s}(\mathrm{n}=25) \\ & \text { 3. Rocuronium } 0.6 \mathrm{mg} / \mathrm{kg} \text { intubated } 60 \mathrm{~s} \text { with lidocaine } 1.5 \mathrm{mg} / \mathrm{kg}(\mathrm{n}=25)^{*} \\ & \text { 4. Rocuronium } 0.6 \mathrm{mg} / \mathrm{kg} \text { intubated } 90 \mathrm{~s}(\mathrm{n}=25)^{\star} \\ & \text { 5. Rocuronium } 0.6 \mathrm{mg} / \mathrm{kg} \text { intubated } 90 \mathrm{~s} \text { with lidocaine } 1.5 \mathrm{mg} / \mathrm{kg}(\mathrm{n}=25)^{*} \\ & \text { Premedication: atropine } 0.5 \mathrm{mg} / \mathrm{kg} \text {, pethidine } 50 \mathrm{mg} \mathrm{im} \\ & \text { Sequence with: alfentanyl } 10 \mathrm{mcg} / \mathrm{kg} \text {, propofol } 2 \mathrm{mg} / \mathrm{kg}\end{aligned}$

Outcomes $\begin{aligned} & \text { 1. Intubating conditions } 60 \text { or } 90 \text { s after end of muscle relaxant injection. Reported as excellent, good, } \\ & \text { poor and inadequate as per Goldberg et al, based on vocal cords and coughing } \\ & \text { 2. Haemodynamic changes }\end{aligned}$

\begin{tabular}{ll}
\hline Adverse events & None reported \\
\hline Time \& Place & Study dates not reported. Article accepted November 2002 \\
& University of Ankara, Ankara, Turkey \\
\hline
\end{tabular}

Funding and declarations Funding source: none declared

Declarations of interest: none declared

Notes Efficacy analysis

\section{Risk of bias}

Bias Authors' judgement Support for judgement


Yorukoglu 2003 (Continued) $\begin{array}{ll}\begin{array}{l}\text { Random sequence genera- } \\ \text { tion (selection bias) }\end{array} & \text { "Patients were randomly allocated into five groups using a computer-generat- } \\ \end{array}$

$\begin{array}{ll}\begin{array}{l}\text { Allocation concealment } \quad \text { Low risk } \\ \text { (selection bias) }\end{array} & \begin{array}{l}\text { "patients and the intubating anesthetist were blinded to the study solutions } \\ \text { administered" }\end{array}\end{array}$

\begin{tabular}{|c|c|c|}
\hline $\begin{array}{l}\text { Blinding of participants } \\
\text { and personnel (perfor- } \\
\text { mance bias) } \\
\text { All outcomes }\end{array}$ & Low risk & $\begin{array}{l}\text { Participant asleep and personnel performance does not affect intubating con- } \\
\text { ditions }\end{array}$ \\
\hline
\end{tabular}

\begin{tabular}{|c|c|c|}
\hline $\begin{array}{l}\text { Blinding of outcome as- } \\
\text { sessment (detection bias) } \\
\text { All outcomes }\end{array}$ & Low risk & $\begin{array}{l}60 \text { or } 90 \text { secs after the end of the muscle relaxant injection, the intubating } \\
\text { anaesthesist was called to enter the study room and the intubating anaesthe- } \\
\text { sist was instructed by an assistant to start laryngoscopy }\end{array}$ \\
\hline $\begin{array}{l}\text { Incomplete outcome data } \\
\text { (attrition bias) } \\
\text { All outcomes }\end{array}$ & Low risk & 125 participants were enrolled and all completed the study \\
\hline $\begin{array}{l}\text { Selective reporting (re- } \\
\text { porting bias) }\end{array}$ & Low risk & All outcomes reported \\
\hline
\end{tabular}

* Not used in analysis

ASA status: American Society of Anesthesia score I - IV, determined by health (decreased health as score increases)

BMI: Body mass index, $\mathrm{kg} / \mathrm{m}^{2}$

EMG: electromyogram

i.m: intramuscular

IOP: Intraocular pressure

ITT: Intention-to-treat

iv: intravenous

$\mathrm{N}$ : number

OR: operating room

po: per os

$\mathrm{R}$ : rocuronium

RAE: name of endotracheal tube

$\mathrm{RCT}$ : randomized controlled trial

RSI: rapid sequence induction

$\mathrm{S}$ : succinylcholine

$\mathrm{s}$ : seconds

SBP: systolic blood pressure

$\mathrm{T}_{1}$ : first twitch of train of four

TOF: train-of-four

Characteristics of excluded studies [ordered by study ID]

\begin{tabular}{ll}
\hline Study & Reason for exclusion \\
\hline Dobson 1999 & $\begin{array}{l}\text { Only looked at rocuronium with propofol versus rocuronium with thiopental without comparing to } \\
\text { succinylcholine }\end{array}$ \\
\hline Dubois 1992 & No comparison with succinylcholine \\
\hline Hemmerling 2000 & No outcome of intubation conditions \\
\hline Huizinga 1992 & $\begin{array}{l}\text { The control group used not only succinylcholine but also gallamine in the sequence which cannot } \\
\text { be controlled for when combining studies }\end{array}$ \\
\hline
\end{tabular}




\begin{tabular}{|c|c|}
\hline Study & Reason for exclusion \\
\hline Lam 1997 & Abstract data only. Unclear what intubation scores were based on results given \\
\hline Martin 1998 & $\begin{array}{l}\text { No comparison of single intubating dose of rocuronium versus succinylcholine. Study looks at } \\
\text { priming dose of non-depolarizing muscle relaxants with succinylcholine only }\end{array}$ \\
\hline Misiolek 2009 & Used double lumen tubes \\
\hline Naguib 1994b & No comparison with succinylcholine \\
\hline Ortiz-Gómez 2005 & $\begin{array}{l}\text { RCT but intubation condition data is presented in graphic form only and cannot be reliably extract- } \\
\text { ed }\end{array}$ \\
\hline Robertson 2004 & No outcome of intubation conditions \\
\hline Stourac 2013 & Conference abstract only, no data could be abstracted \\
\hline Vianna 1997 & Does not document intubation scores in paper \\
\hline Vincent 1996 & $\begin{array}{l}\text { Abstract only. Unable to obtain document from North American source. Will reconsider if able to } \\
\text { obtain in future }\end{array}$ \\
\hline Woolf 1997 & Did not record intubating conditions, measures other parameters only \\
\hline
\end{tabular}

$\mathrm{RCT}=$ randomized controlled trial

$\mathrm{RSI}$ : rapid sequence intubation

\section{DATA AND ANALYSES}

\section{Comparison 1. Rocuronium any dose versus succinylcholine}

\begin{tabular}{|c|c|c|c|c|}
\hline Outcome or subgroup title & $\begin{array}{l}\text { No. of } \\
\text { studies }\end{array}$ & $\begin{array}{l}\text { No. of } \\
\text { partici- } \\
\text { pants }\end{array}$ & Statistical method & Effect size \\
\hline $\begin{array}{l}1 \text { Excellent versus other intubation condi- } \\
\text { tions }\end{array}$ & 50 & 4151 & Risk Ratio (M-H, Random, 95\% Cl) & $0.86[0.81,0.92]$ \\
\hline 1.1 Simulated RSI & 23 & 2535 & Risk Ratio (M-H, Random, 95\% Cl) & $0.80[0.72,0.89]$ \\
\hline 1.2 Modified RSI & 25 & 1468 & Risk Ratio (M-H, Random, 95\% Cl) & $0.92[0.85,0.99]$ \\
\hline 1.3 Mixed simulated and modified RSI & 2 & 148 & Risk Ratio (M-H, Random, 95\% Cl) & $0.59[0.33,1.08]$ \\
\hline $\begin{array}{l}2 \text { Acceptable versus suboptimal intubation } \\
\text { conditions }\end{array}$ & 48 & 3992 & Risk Ratio (M-H, Random, 95\% Cl) & $0.97[0.95,0.99]$ \\
\hline 2.1 Simulated RSI & 22 & 2416 & Risk Ratio (M-H, Random, 95\% Cl) & $0.94[0.90,0.98]$ \\
\hline 2.2 Modified RSI & 24 & 1428 & Risk Ratio (M-H, Random, 95\% Cl) & $1.00[0.99,1.01]$ \\
\hline 2.3 Mixed simulated and modified RSI & 2 & 148 & Risk Ratio (M-H, Random, 95\% Cl) & $0.82[0.66,1.01]$ \\
\hline
\end{tabular}


Analysis 1.1. Comparison 1 Rocuronium any dose versus succinylcholine, Outcome 1 Excellent versus other intubation conditions.

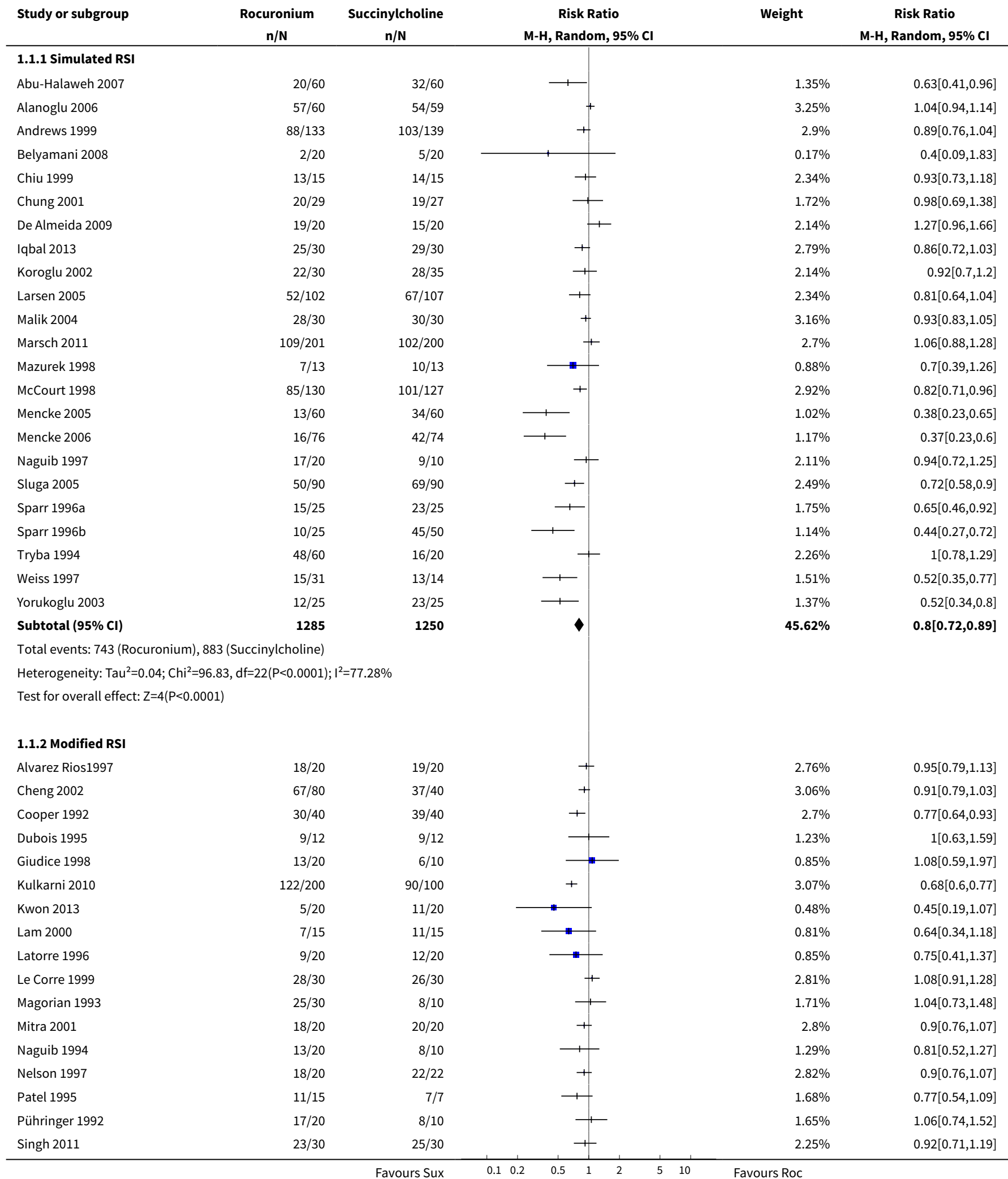




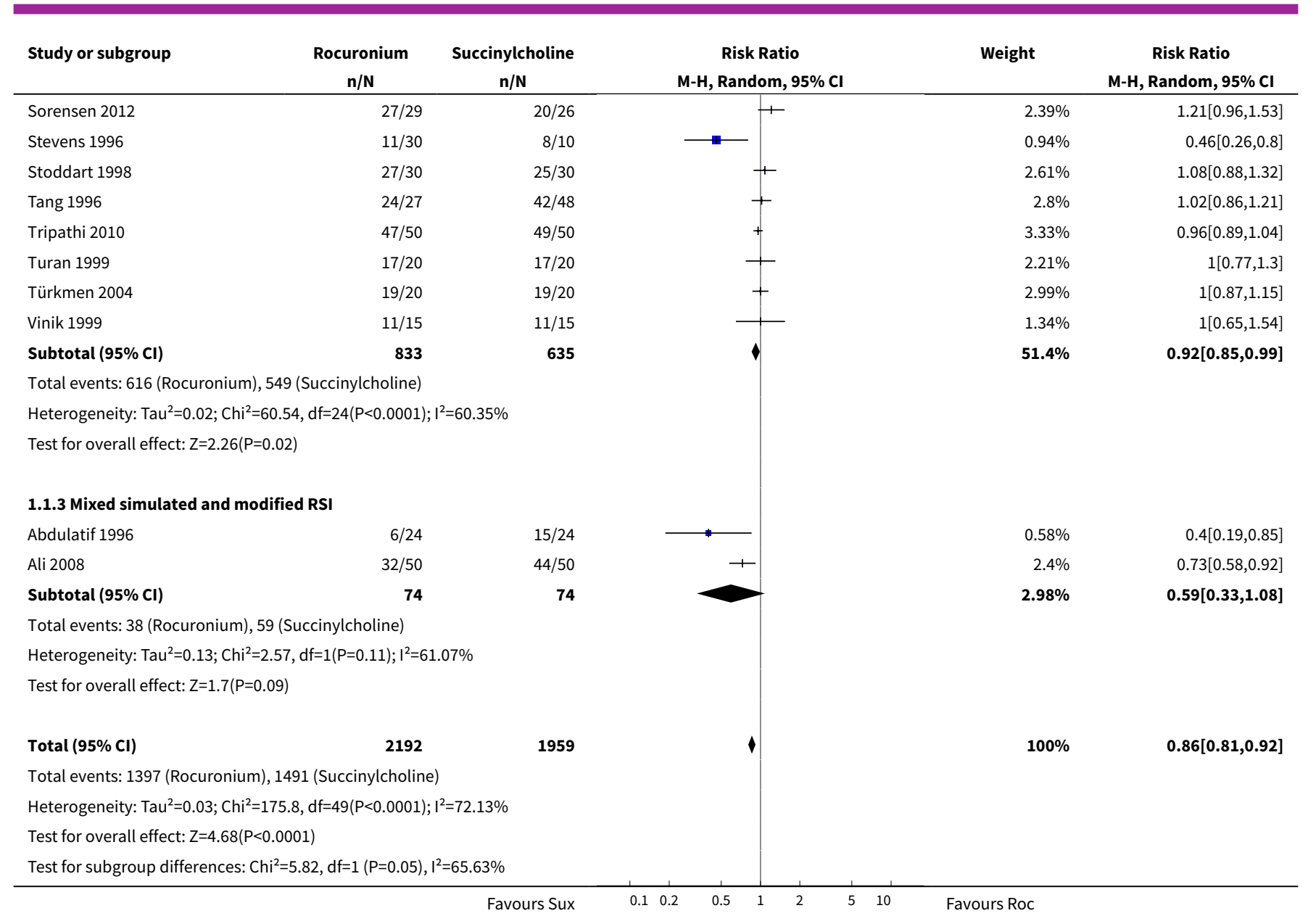

Analysis 1.2. Comparison 1 Rocuronium any dose versus succinylcholine, Outcome 2 Acceptable versus suboptimal intubation conditions.

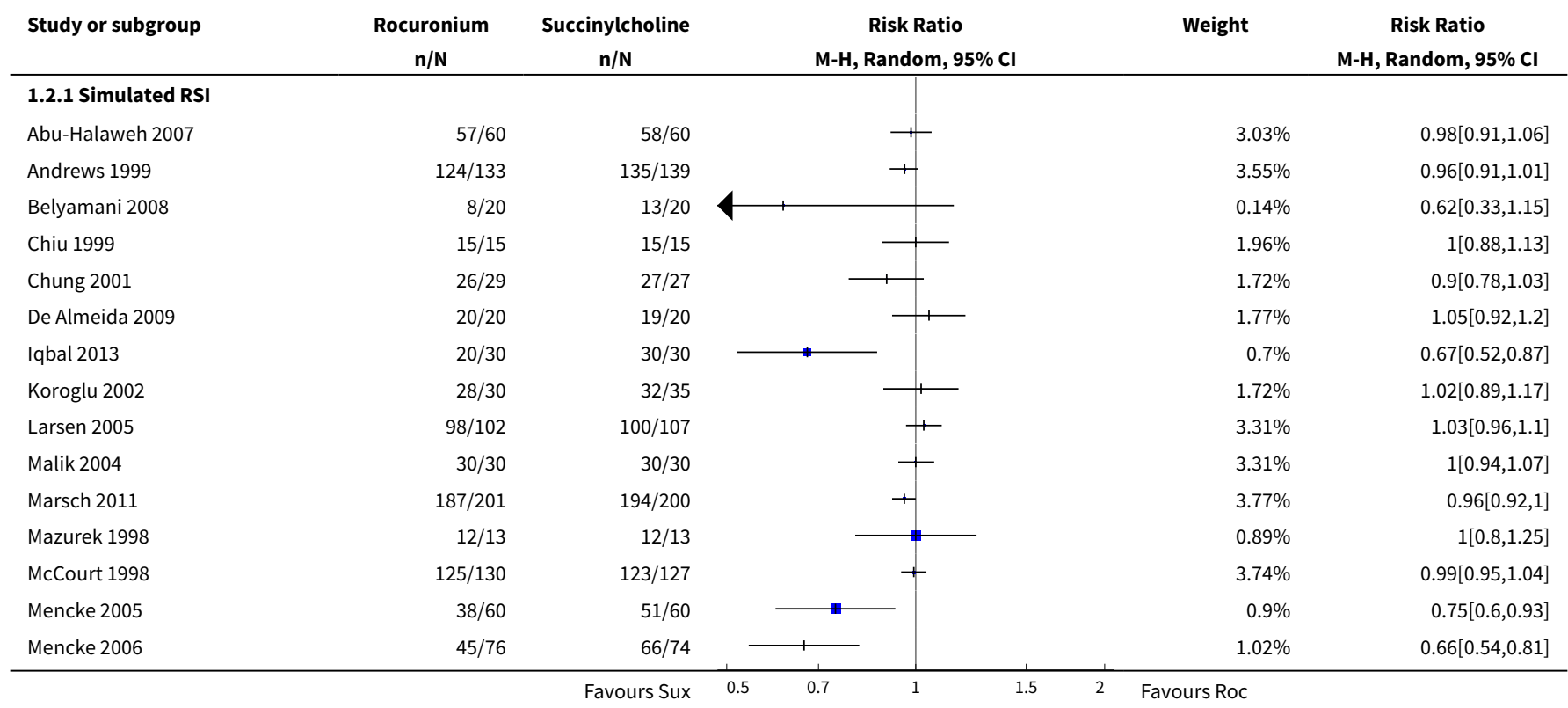




\begin{tabular}{|c|c|c|c|c|c|c|c|c|}
\hline \multirow{2}{*}{$\begin{array}{l}\text { Study or subgroup } \\
\text { Naguib } 1997\end{array}$} & \multirow{2}{*}{$\begin{array}{l}\begin{array}{l}\text { Rocuronium } \\
\text { n/N }\end{array} \\
20 / 20\end{array}$} & \multirow{2}{*}{$\begin{array}{l}\begin{array}{l}\text { Succinylcholine } \\
\mathbf{n} / \mathbf{N}\end{array} \\
10 / 10\end{array}$} & \multicolumn{3}{|c|}{$\begin{array}{c}\text { Risk Ratio } \\
\text { M-H, Random, 95\% Cl } \\
\end{array}$} & & Weight & \multirow{2}{*}{$\begin{array}{c}\text { Risk Ratio } \\
\text { M-H, Random, 95\% Cl }\end{array}$} \\
\hline & & & & . & 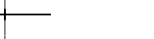 & & $1.63 \%$ & \\
\hline Sluga 2005 & $78 / 90$ & $83 / 90$ & & $\longrightarrow$ & - & & $2.42 \%$ & $0.94[0.85,1.04]$ \\
\hline Sparr 1996a & $24 / 25$ & $25 / 25$ & & $\longrightarrow$ & - & & $2.24 \%$ & $0.96[0.86,1.07]$ \\
\hline Sparr 1996b & $20 / 25$ & $50 / 50$ & & - & & & $1.04 \%$ & $0.8[0.65,0.97]$ \\
\hline Tryba 1994 & $53 / 60$ & $20 / 20$ & & + & & & $2.13 \%$ & $0.9[0.8,1.01]$ \\
\hline Weiss 1997 & $21 / 31$ & $13 / 14$ & & - & & & $0.59 \%$ & $0.73[0.55,0.97]$ \\
\hline Yorukoglu 2003 & $24 / 25$ & $25 / 25$ & & -1 & - & & $2.24 \%$ & $0.96[0.86,1.07]$ \\
\hline Subtotal $(95 \% \mathrm{Cl})$ & 1225 & 1191 & & $>$ & & & $43.82 \%$ & $0.94[0.9,0.98]$ \\
\hline \multicolumn{9}{|c|}{ Total events: 1073 (Rocuronium), 1131 (Succinylcholine) } \\
\hline \multicolumn{9}{|c|}{ Heterogeneity: $\mathrm{Tau}^{2}=0.01 ; \mathrm{Chi}^{2}=69.18, \mathrm{df}=21(\mathrm{P}<0.0001) ; \mathrm{I}^{2}=69.65 \%$} \\
\hline \multicolumn{9}{|c|}{ Test for overall effect: $\mathrm{Z}=2.88(\mathrm{P}=0)$} \\
\hline \multicolumn{9}{|l|}{ 1.2.2 Modified RSI } \\
\hline Alvarez Rios1997 & $20 / 20$ & $20 / 20$ & & $\longrightarrow$ & — & & $2.56 \%$ & $1[0.91,1.1]$ \\
\hline Cheng 2002 & $75 / 80$ & $40 / 40$ & & + & & & $3.2 \%$ & $0.94[0.88,1.01]$ \\
\hline Cooper 1992 & $39 / 40$ & $40 / 40$ & & $一$ & & & $3.18 \%$ & $0.98[0.91,1.04]$ \\
\hline Dubois 1995 & $12 / 12$ & $11 / 12$ & & & & & $0.87 \%$ & $1.09[0.87,1.36]$ \\
\hline Giudice 1998 & $20 / 20$ & $10 / 10$ & & 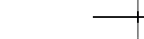 & & & $1.63 \%$ & $1[0.86,1.16]$ \\
\hline Kulkarni 2010 & $200 / 200$ & $100 / 100$ & & & & & $4.3 \%$ & $1[0.98,1.02]$ \\
\hline Kwon 2013 & $17 / 20$ & $18 / 20$ & & & & & $0.81 \%$ & $0.94[0.75,1.19]$ \\
\hline Lam 2000 & $13 / 15$ & $15 / 15$ & & 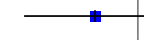 & - & & $0.85 \%$ & $0.87[0.69,1.09]$ \\
\hline Latorre 1996 & $18 / 20$ & $18 / 20$ & & & & & $0.99 \%$ & $1[0.81,1.23]$ \\
\hline Le Corre 1999 & $30 / 30$ & $30 / 30$ & & & + & & $3.31 \%$ & $1[0.94,1.07]$ \\
\hline Magorian 1993 & $30 / 30$ & $10 / 10$ & & & - & & $1.76 \%$ & $1[0.87,1.15]$ \\
\hline Mitra 2001 & $20 / 20$ & $20 / 20$ & & $\longrightarrow$ & + & & $2.56 \%$ & $1[0.91,1.1]$ \\
\hline Naguib 1994 & $20 / 20$ & $10 / 10$ & & & 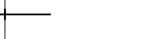 & & $1.63 \%$ & $1[0.86,1.16]$ \\
\hline Nelson 1997 & $20 / 20$ & $22 / 22$ & & - & + & & $2.65 \%$ & $1[0.91,1.09]$ \\
\hline Patel 1995 & $14 / 15$ & $7 / 7$ & & 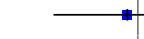 & & & $0.79 \%$ & $0.97[0.76,1.23]$ \\
\hline Pühringer 1992 & $20 / 20$ & $9 / 10$ & & & $\longrightarrow$ & & $0.76 \%$ & $1.13[0.89,1.44]$ \\
\hline Singh 2011 & $29 / 30$ & $30 / 30$ & & - & - & & $2.63 \%$ & $0.97[0.88,1.06]$ \\
\hline Sorensen 2012 & $29 / 29$ & $26 / 26$ & & 7 & + & & $3.16 \%$ & $1[0.93,1.07]$ \\
\hline Stevens 1996 & $29 / 30$ & $10 / 10$ & & 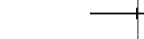 & - & & $1.55 \%$ & $1[0.86,1.16]$ \\
\hline Stoddart 1998 & $30 / 30$ & $30 / 30$ & & & 十 & & $3.31 \%$ & $1[0.94,1.07]$ \\
\hline Tang 1996 & $27 / 27$ & $47 / 48$ & & - & 1 & & $3.14 \%$ & $1.01[0.94,1.09]$ \\
\hline Tripathi 2010 & $50 / 50$ & $50 / 50$ & & & + & & $3.92 \%$ & $1[0.96,1.04]$ \\
\hline Turan 1999 & $20 / 20$ & $20 / 20$ & & $\longrightarrow$ & + & & $2.56 \%$ & $1[0.91,1.1]$ \\
\hline Vinik 1999 & $14 / 15$ & $14 / 15$ & & 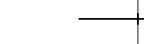 & + & & $1.12 \%$ & $1[0.83,1.21]$ \\
\hline Subtotal $(95 \% \mathrm{Cl})$ & 813 & 615 & & & 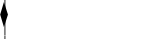 & & $53.24 \%$ & $1[0.99,1.01]$ \\
\hline \multicolumn{9}{|c|}{ Total events: 796 (Rocuronium), 607 (Succinylcholine) } \\
\hline \multicolumn{9}{|c|}{ Heterogeneity: $\operatorname{Tau}^{2}=0 ; \mathrm{Chi}^{2}=7.68, \mathrm{df}=23(\mathrm{P}=1) ; \mathrm{I}^{2}=0 \%$} \\
\hline \multicolumn{9}{|c|}{ Test for overall effect: $Z=0.46(P=0.64)$} \\
\hline \multicolumn{9}{|c|}{ 1.2.3 Mixed simulated and modified RSI } \\
\hline Abdulatif 1996 & $17 / 24$ & $24 / 24$ & & $\rightarrow$ & & & $0.67 \%$ & $0.71[0.55,0.93]$ \\
\hline Ali 2008 & $44 / 50$ & $50 / 50$ & & + & & & $2.26 \%$ & $0.88[0.79,0.98]$ \\
\hline Subtotal $(95 \% \mathrm{Cl})$ & 74 & 74 & & & & & $2.93 \%$ & $0.82[0.66,1.01]$ \\
\hline \multicolumn{9}{|c|}{ Total events: 61 (Rocuronium), 74 (Succinylcholine) } \\
\hline \multicolumn{9}{|c|}{ Heterogeneity: $\mathrm{Tau}^{2}=0.02 ; \mathrm{Chi}^{2}=2.52, \mathrm{df}=1(\mathrm{P}=0.11) ; \mathrm{I}^{2}=60.36 \%$} \\
\hline \multicolumn{9}{|c|}{ Test for overall effect: $\mathrm{Z}=1.83(\mathrm{P}=0.07)$} \\
\hline Total $(95 \% \mathrm{Cl})$ & 2112 & 1880 & & $\checkmark$ & & & $100 \%$ & $0.97[0.95,0.99]$ \\
\hline \multicolumn{9}{|c|}{ Total events: 1930 (Rocuronium), 1812 (Succinylcholine) } \\
\hline & & Favours Sux & 0.5 & 0.7 & 1.5 & 2 & Favours Roc & \\
\hline
\end{tabular}




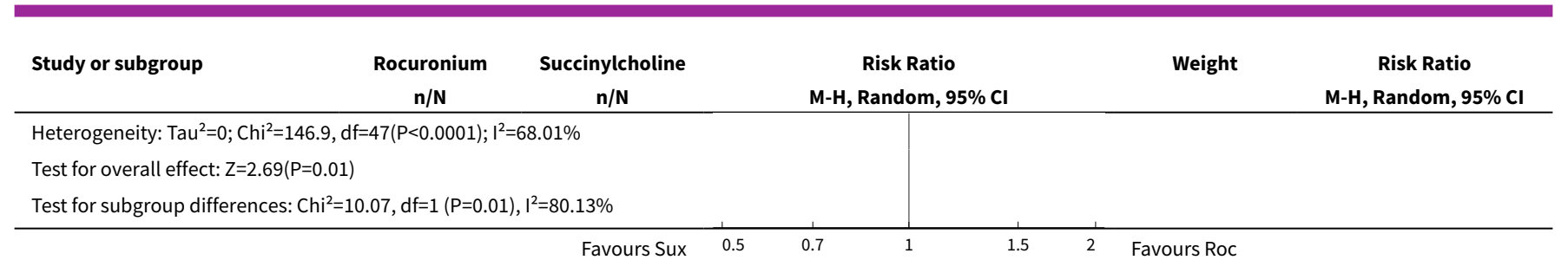

Comparison 2. Rocuronium specific dose versus succinylcholine

\begin{tabular}{lllll}
\hline Outcome or subgroup title & $\begin{array}{l}\text { No. of } \\
\text { studies }\end{array}$ & $\begin{array}{l}\text { No. of } \\
\text { partici- } \\
\text { pants }\end{array}$ & Statistical method & Effect size \\
\hline $\begin{array}{l}1 \text { Excellent versus other intuba- } \\
\text { tion conditions }\end{array}$ & 50 & 4352 & Risk Ratio (M-H, Random, 95\% Cl) & $0.86[0.81,0.92]$ \\
\hline 1.1 Rocuronium $0.6-0.7 \mathrm{mg} / \mathrm{kg}$ & 39 & 2808 & Risk Ratio (M-H, Random, 95\% Cl) & $0.80[0.72,0.88]$ \\
\hline 1.2 Rocuronium $0.9-1.0 \mathrm{mg} / \mathrm{kg}$ & 16 & 1458 & Risk Ratio (M-H, Random, 95\% Cl) & $0.95[0.89,1.00]$ \\
\hline 1.3 Rocuronium $1.2 \mathrm{mg} / \mathrm{kg}$ & 3 & 86 & Risk Ratio (M-H, Random, 95\% Cl) & $0.93[0.75,1.15]$ \\
\hline $\begin{array}{l}2 \text { Acceptable versus suboptimal } \\
\text { intubation conditions }\end{array}$ & 48 & 4193 & Risk Ratio (M-H, Random, 95\% Cl) & $0.98[0.96,0.99]$ \\
\hline 2.1 Rocuronium $0.6-0.7 \mathrm{mg} / \mathrm{kg}$ & 38 & 2768 & Risk Ratio (M-H, Random, 95\% Cl) & $0.96[0.93,0.99]$ \\
\hline 2.2 Rocuronium $0.9-1.0 \mathrm{mg} / \mathrm{kg}$ & 15 & 1339 & Risk Ratio (M-H, Random, 95\% Cl) & $1.00[0.98,1.01]$ \\
\hline 2.3 Rocuronium $1.2 \mathrm{mg} / \mathrm{kg}$ & 3 & 86 & Risk Ratio (M-H, Random, 95\% Cl) & $1.0[0.92,1.08]$ \\
\hline
\end{tabular}

Analysis 2.1. Comparison 2 Rocuronium specific dose versus succinylcholine, Outcome 1 Excellent versus other intubation conditions.

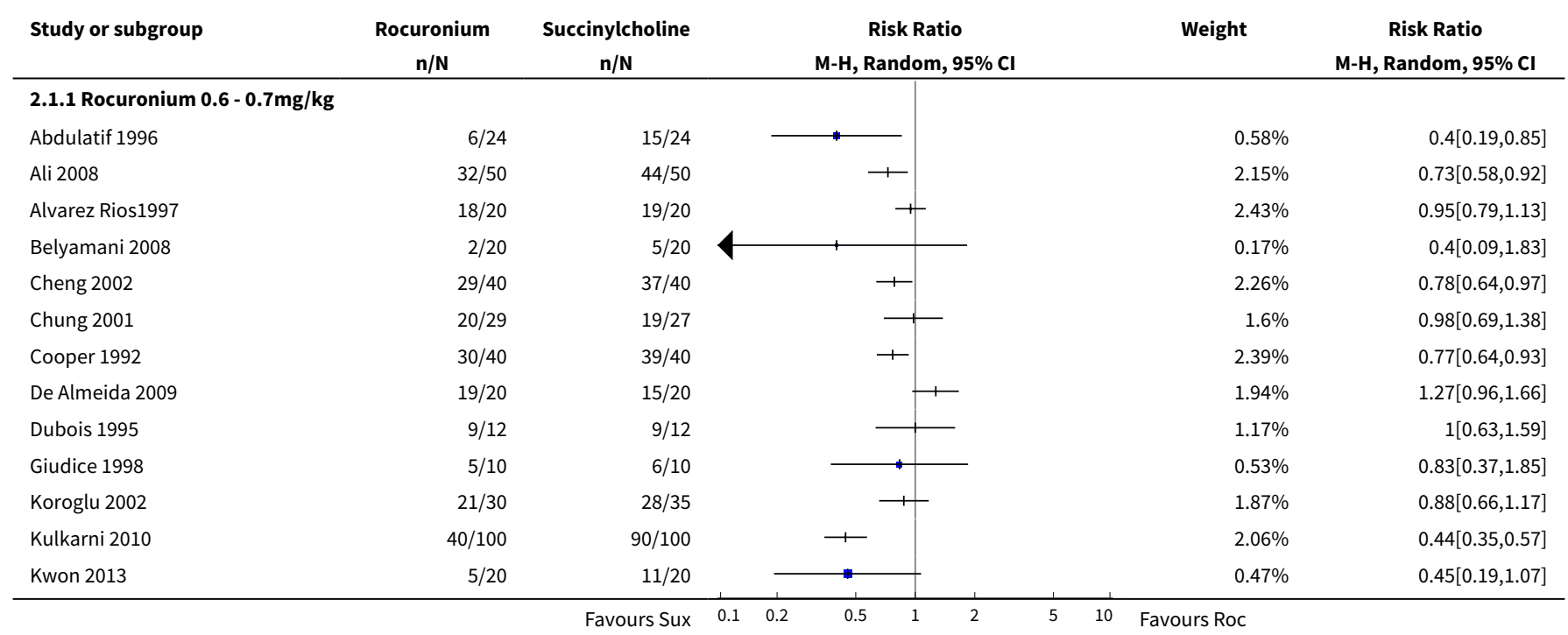




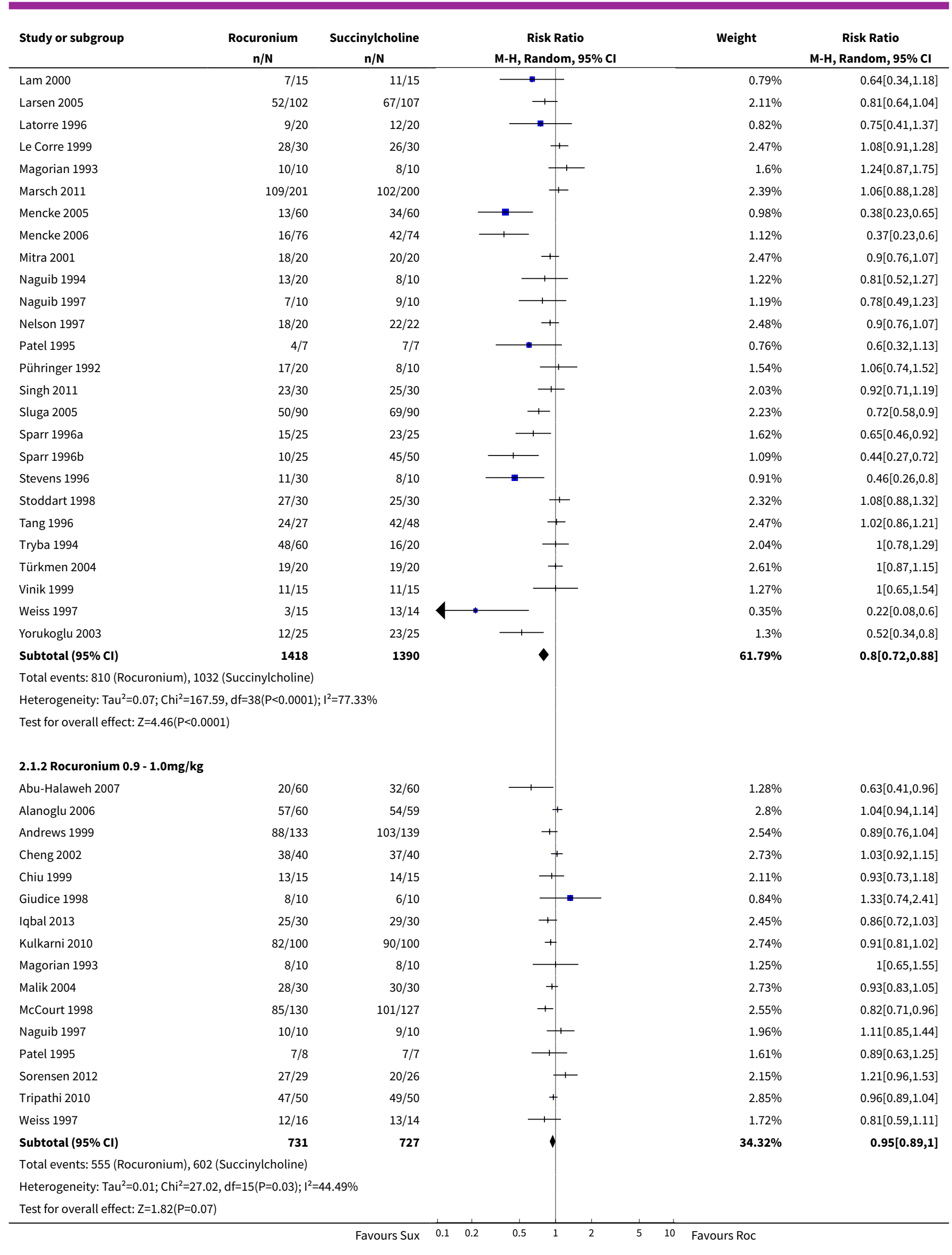




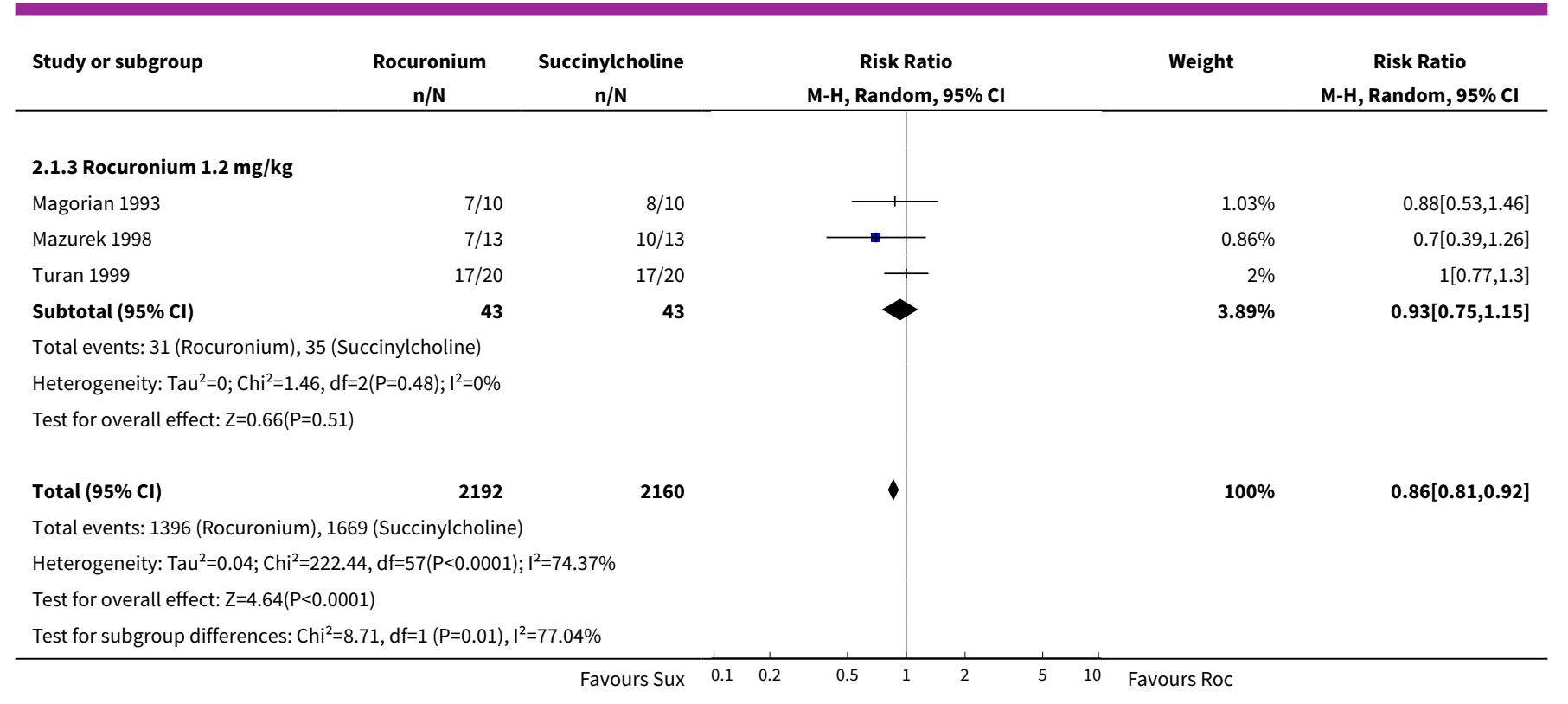

Analysis 2.2. Comparison 2 Rocuronium specific dose versus succinylcholine, Outcome 2 Acceptable versus suboptimal intubation conditions.

\begin{tabular}{|c|c|c|c|c|c|}
\hline Study or subgroup & $\begin{array}{c}\text { Rocuronium } \\
n / N\end{array}$ & $\begin{array}{c}\text { Succinylcholine } \\
n / N\end{array}$ & $\begin{array}{c}\text { Risk Ratio } \\
\text { M-H, Random, } 95 \% \mathrm{CI}\end{array}$ & Weight & $\begin{array}{c}\text { Risk Ratio } \\
\text { M-H, Random, } 95 \% \mathrm{Cl}\end{array}$ \\
\hline \multicolumn{6}{|c|}{ 2.2.1 Rocuronium $0.6-0.7 \mathrm{mg} / \mathrm{kg}$} \\
\hline Abdulatif 1996 & $17 / 24$ & $24 / 24$ & $\longrightarrow$ & $0.49 \%$ & $0.71[0.55,0.93]$ \\
\hline Ali 2008 & $44 / 50$ & $50 / 50$ & + & $1.9 \%$ & $0.88[0.79,0.98]$ \\
\hline Alvarez Rios1997 & $20 / 20$ & $20 / 20$ & & $2.22 \%$ & $1[0.91,1.1]$ \\
\hline Belyamani 2008 & $8 / 20$ & $13 / 20$ & - & $0.09 \%$ & $0.62[0.33,1.15]$ \\
\hline Cheng 2002 & $36 / 40$ & $40 / 40$ & + & $1.82 \%$ & $0.9[0.81,1.01]$ \\
\hline Chung 2001 & $26 / 29$ & $27 / 27$ & + & $1.37 \%$ & $0.9[0.78,1.03]$ \\
\hline Cooper 1992 & $39 / 40$ & $40 / 40$ & & $2.95 \%$ & $0.98[0.91,1.04]$ \\
\hline De Almeida 2009 & $20 / 20$ & $19 / 20$ & - & $1.42 \%$ & $1.05[0.92,1.2]$ \\
\hline Dubois 1995 & $12 / 12$ & $11 / 12$ & * - & $0.65 \%$ & $1.09[0.87,1.36]$ \\
\hline Giudice 1998 & $10 / 10$ & $10 / 10$ & & $0.91 \%$ & $1[0.83,1.2]$ \\
\hline Koroglu 2002 & $28 / 30$ & $32 / 35$ & & $1.37 \%$ & $1.02[0.89,1.17]$ \\
\hline Kulkarni 2010 & $100 / 100$ & $100 / 100$ & & $4.45 \%$ & $1[0.98,1.02]$ \\
\hline Kwon 2013 & $17 / 20$ & $18 / 20$ & $\longrightarrow$ & $0.6 \%$ & $0.94[0.75,1.19]$ \\
\hline Lam 2000 & $13 / 15$ & $15 / 15$ & $\rightarrow$ & $0.63 \%$ & $0.87[0.69,1.09]$ \\
\hline Larsen 2005 & $98 / 102$ & $100 / 107$ & t & $3.11 \%$ & $1.03[0.96,1.1]$ \\
\hline Latorre 1996 & $18 / 20$ & $18 / 20$ & & $0.74 \%$ & $1[0.81,1.23]$ \\
\hline Le Corre 1999 & $30 / 30$ & $30 / 30$ & - & $3.11 \%$ & $1[0.94,1.07]$ \\
\hline Magorian 1993 & $10 / 10$ & $10 / 10$ & - & $0.91 \%$ & $1[0.83,1.2]$ \\
\hline Marsch 2011 & $187 / 201$ & $194 / 200$ & + & $3.73 \%$ & $0.96[0.92,1]$ \\
\hline Mencke 2005 & $38 / 60$ & $51 / 60$ & $\longrightarrow$ & $0.67 \%$ & $0.75[0.6,0.93]$ \\
\hline Mencke 2006 & $45 / 76$ & $66 / 74$ & $\longrightarrow$ & $0.77 \%$ & $0.66[0.54,0.81]$ \\
\hline Mitra 2001 & $20 / 20$ & $20 / 20$ & - & $2.22 \%$ & $1[0.91,1.1]$ \\
\hline Naguib 1994 & $20 / 20$ & $10 / 10$ & + & $1.3 \%$ & $1[0.86,1.16]$ \\
\hline Naguib 1997 & $10 / 10$ & $10 / 10$ & - & $0.91 \%$ & $1[0.83,1.2]$ \\
\hline Nelson 1997 & $20 / 20$ & $22 / 22$ & - & $2.32 \%$ & $1[0.91,1.09]$ \\
\hline Patel 1995 & $6 / 7$ & $7 / 7$ & - & $0.25 \%$ & $0.87[0.59,1.26]$ \\
\hline
\end{tabular}




\begin{tabular}{|c|c|c|c|c|c|}
\hline Study or subgroup & $\begin{array}{c}\text { Rocuronium } \\
n / N\end{array}$ & $\begin{array}{c}\text { Succinylcholine } \\
n / \mathbf{N}\end{array}$ & $\begin{array}{c}\text { Risk Ratio } \\
\text { M-H, Random, } 95 \% \mathrm{Cl}\end{array}$ & Weight & $\begin{array}{c}\text { Risk Ratio } \\
\text { M-H, Random, } 95 \% \mathrm{Cl}\end{array}$ \\
\hline Pühringer 1992 & $20 / 20$ & $9 / 10$ & - & $0.56 \%$ & $1.13[0.89,1.44]$ \\
\hline Singh 2011 & $29 / 30$ & $30 / 30$ & + & $2.3 \%$ & $0.97[0.88,1.06]$ \\
\hline Sluga 2005 & $78 / 90$ & $83 / 90$ & + & $2.07 \%$ & $0.94[0.85,1.04]$ \\
\hline Sparr 1996a & $24 / 25$ & $25 / 25$ & + & $1.89 \%$ & $0.96[0.86,1.07]$ \\
\hline Sparr 1996b & $20 / 25$ & $50 / 50$ & $\longrightarrow$ & $0.78 \%$ & $0.8[0.65,0.97]$ \\
\hline Stevens 1996 & $29 / 30$ & $10 / 10$ & 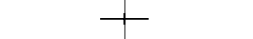 & $1.22 \%$ & $1[0.86,1.16]$ \\
\hline Stoddart 1998 & $30 / 30$ & $30 / 30$ & & $3.11 \%$ & $1[0.94,1.07]$ \\
\hline Tang 1996 & $27 / 27$ & $47 / 48$ & & $2.89 \%$ & $1.01[0.94,1.09]$ \\
\hline Tryba 1994 & $53 / 60$ & $20 / 20$ & + & $1.77 \%$ & $0.9[0.8,1.01]$ \\
\hline Vinik 1999 & $14 / 15$ & $14 / 15$ & & $0.85 \%$ & $1[0.83,1.21]$ \\
\hline Weiss 1997 & $7 / 15$ & $13 / 14$ & - & $0.12 \%$ & $0.5[0.29,0.88]$ \\
\hline Yorukoglu 2003 & $24 / 25$ & $25 / 25$ & $\rightarrow$ & $1.89 \%$ & $0.96[0.86,1.07]$ \\
\hline Subtotal $(95 \% \mathrm{Cl})$ & 1398 & 1370 & $\checkmark$ & $60.35 \%$ & $0.96[0.93,0.99]$ \\
\hline \multicolumn{6}{|c|}{ Total events: 1247 (Rocuronium), 1313 (Succinylcholine) } \\
\hline \multicolumn{6}{|c|}{ Heterogeneity: $\mathrm{Tau}^{2}=0.01 ; \mathrm{Chi}^{2}=130.83, \mathrm{df}=37(\mathrm{P}<0.0001) ; \mathrm{I}^{2}=71.72 \%$} \\
\hline \multicolumn{6}{|c|}{ Test for overall effect: $Z=2.57(P=0.01)$} \\
\hline \multicolumn{6}{|c|}{ 2.2.2 Rocuronium $0.9-1.0 \mathrm{mg} / \mathrm{kg}$} \\
\hline Abu-Halaweh 2007 & $57 / 60$ & $58 / 60$ & + & $2.76 \%$ & $0.98[0.91,1.06]$ \\
\hline Andrews 1999 & $124 / 133$ & $135 / 139$ & + & $3.43 \%$ & $0.96[0.91,1.01]$ \\
\hline Cheng 2002 & $39 / 40$ & $40 / 40$ & + & $2.95 \%$ & $0.98[0.91,1.04]$ \\
\hline Chiu 1999 & $15 / 15$ & $15 / 15$ & - & $1.6 \%$ & $1[0.88,1.13]$ \\
\hline Giudice 1998 & $10 / 10$ & $10 / 10$ & - & $0.91 \%$ & $1[0.83,1.2]$ \\
\hline Iqbal 2013 & $30 / 30$ & $30 / 30$ & $t$ & $3.11 \%$ & $1[0.94,1.07]$ \\
\hline Kulkarni 2010 & $100 / 100$ & $100 / 100$ & & $4.45 \%$ & $1[0.98,1.02]$ \\
\hline Magorian 1993 & $10 / 10$ & $10 / 10$ & & $0.91 \%$ & $1[0.83,1.2]$ \\
\hline Malik 2004 & $30 / 30$ & $30 / 30$ & + & $3.11 \%$ & $1[0.94,1.07]$ \\
\hline McCourt 1998 & $125 / 130$ & $123 / 127$ & $t$ & $3.68 \%$ & $0.99[0.95,1.04]$ \\
\hline Naguib 1997 & $10 / 10$ & $10 / 10$ & & $0.91 \%$ & $1[0.83,1.2]$ \\
\hline Patel 1995 & $8 / 8$ & $7 / 7$ & - & $0.58 \%$ & $1[0.79,1.27]$ \\
\hline Sorensen 2012 & $29 / 29$ & $26 / 26$ & t & $2.92 \%$ & $1[0.93,1.07]$ \\
\hline Tripathi 2010 & $50 / 50$ & $50 / 50$ & & $3.94 \%$ & $1[0.96,1.04]$ \\
\hline Weiss 1997 & $14 / 16$ & $13 / 14$ & $\longrightarrow$ & $0.6 \%$ & $0.94[0.74,1.19]$ \\
\hline Subtotal $(95 \% \mathrm{Cl})$ & 671 & 668 & & $35.86 \%$ & $1[0.98,1.01]$ \\
\hline \multicolumn{6}{|c|}{ Total events: 651 (Rocuronium), 657 (Succinylcholine) } \\
\hline \multicolumn{6}{|c|}{ Heterogeneity: $\mathrm{Tau}^{2}=0 ; \mathrm{Chi}^{2}=4.3, \mathrm{df}=14(\mathrm{P}=0.99) ; \mathrm{I}^{2}=0 \%$} \\
\hline \multicolumn{6}{|c|}{ Test for overall effect: $Z=0.72(P=0.47)$} \\
\hline \multicolumn{6}{|c|}{ 2.2.3 Rocuronium $1.2 \mathrm{mg} / \mathrm{kg}$} \\
\hline Magorian 1993 & $10 / 10$ & $10 / 10$ & $\rightarrow$ & $0.91 \%$ & $1[0.83,1.2]$ \\
\hline Mazurek 1998 & $12 / 13$ & $12 / 13$ & $\longrightarrow$ & $0.66 \%$ & $1[0.8,1.25]$ \\
\hline Turan 1999 & $20 / 20$ & $20 / 20$ & + & $2.22 \%$ & $1[0.91,1.1]$ \\
\hline Subtotal $(95 \% \mathrm{Cl})$ & 43 & 43 & 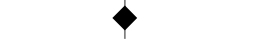 & $3.79 \%$ & $1[0.92,1.08]$ \\
\hline \multicolumn{6}{|c|}{ Total events: 42 (Rocuronium), 42 (Succinylcholine) } \\
\hline \multicolumn{6}{|c|}{ Heterogeneity: Tau $^{2}=0 ; \mathrm{Chi}^{2}=0, \mathrm{df}=2(\mathrm{P}=1) ; \mathrm{I}^{2}=0 \%$} \\
\hline \multicolumn{6}{|c|}{ Test for overall effect: Not applicable } \\
\hline Total $(95 \% \mathrm{Cl})$ & 2112 & 2081 & 1 & $100 \%$ & $0.98[0.96,0.99]$ \\
\hline \multicolumn{6}{|c|}{ Total events: 1940 (Rocuronium), 2012 (Succinylcholine) } \\
\hline \multicolumn{6}{|c|}{ Heterogeneity: $\mathrm{Tau}^{2}=0 ; \mathrm{Chi}^{2}=136.21, \mathrm{df}=55(\mathrm{P}<0.0001) ; \mathrm{I}^{2}=59.62 \%$} \\
\hline \multicolumn{6}{|c|}{ Test for overall effect: $Z=2.49(P=0.01)$} \\
\hline \multicolumn{6}{|c|}{ Test for subgroup differences: $\mathrm{Chi}^{2}=4.45, \mathrm{df}=1(\mathrm{P}=0.11), \mathrm{I}^{2}=55.08 \%$} \\
\hline & & Favours Sux & $0.5 \quad 0.7$ & Favours Roc & \\
\hline
\end{tabular}


Comparison 3. Rocuronium versus succinylcholine for induction agent

\begin{tabular}{|c|c|c|c|c|}
\hline Outcome or subgroup title & $\begin{array}{l}\text { No. of } \\
\text { studies }\end{array}$ & $\begin{array}{l}\text { No. of } \\
\text { partici- } \\
\text { pants }\end{array}$ & Statistical method & Effect size \\
\hline $\begin{array}{l}1 \text { Excellent versus other intubation } \\
\text { conditions }\end{array}$ & 49 & 3750 & Risk Ratio (M-H, Random, 95\% Cl) & $0.85[0.80,0.91]$ \\
\hline 1.1 Propofol & 22 & 1448 & Risk Ratio (M-H, Random, 95\% Cl) & $0.92[0.84,1.01]$ \\
\hline 1.2 Thiopental & 28 & 2302 & Risk Ratio (M-H, Random, 95\% Cl) & $0.81[0.73,0.88]$ \\
\hline $\begin{array}{l}2 \text { Acceptable versus suboptimal intu- } \\
\text { bation conditions }\end{array}$ & 47 & 3591 & Risk Ratio (M-H, Random, 95\% Cl) & $0.97[0.95,1.00]$ \\
\hline 2.1 Propofol & 21 & 1408 & Risk Ratio (M-H, Random, 95\% Cl) & $0.99[0.97,1.01]$ \\
\hline 2.2 Thiopental & 27 & 2183 & Risk Ratio (M-H, Random, 95\% Cl) & $0.96[0.92,0.99]$ \\
\hline
\end{tabular}

Analysis 3.1. Comparison 3 Rocuronium versus succinylcholine for induction agent, Outcome 1 Excellent versus other intubation conditions.

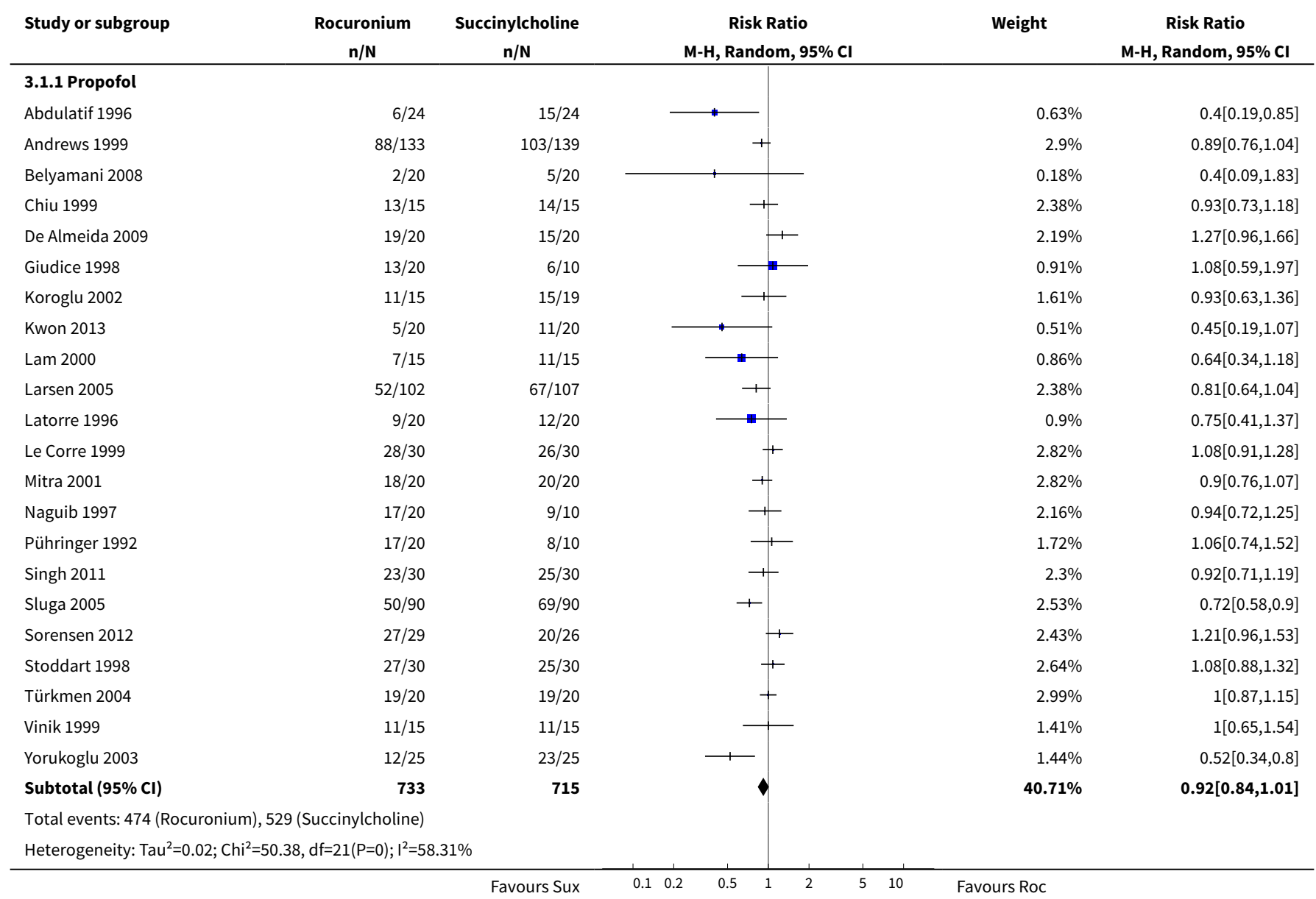




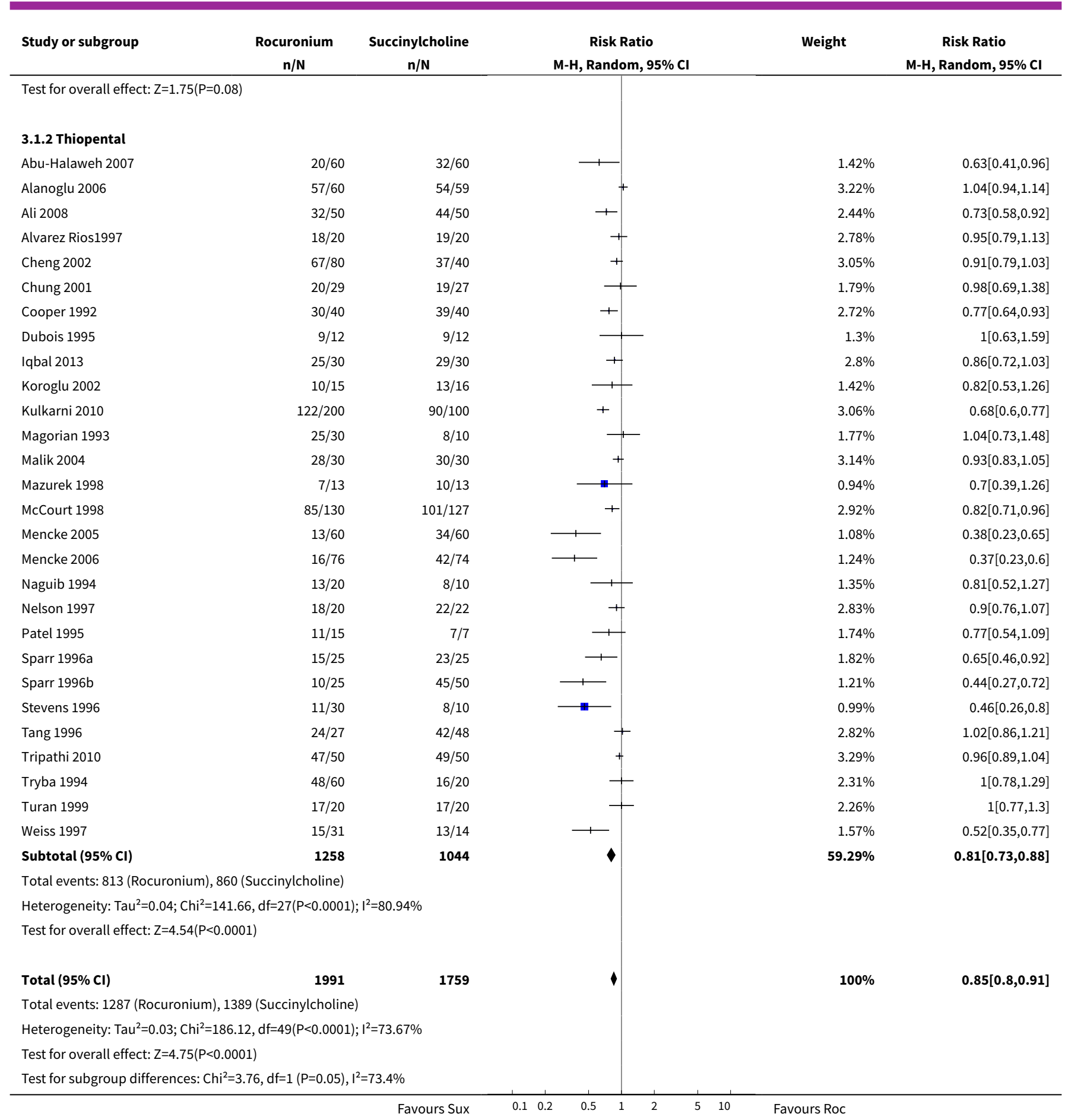

\section{Analysis 3.2. Comparison 3 Rocuronium versus succinylcholine for induction agent, Outcome 2 Acceptable versus suboptimal intubation conditions.}

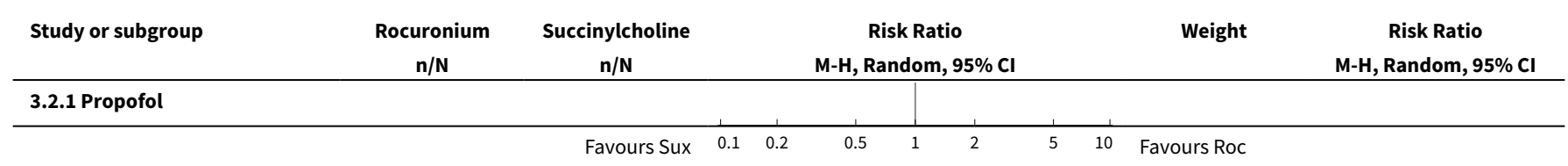




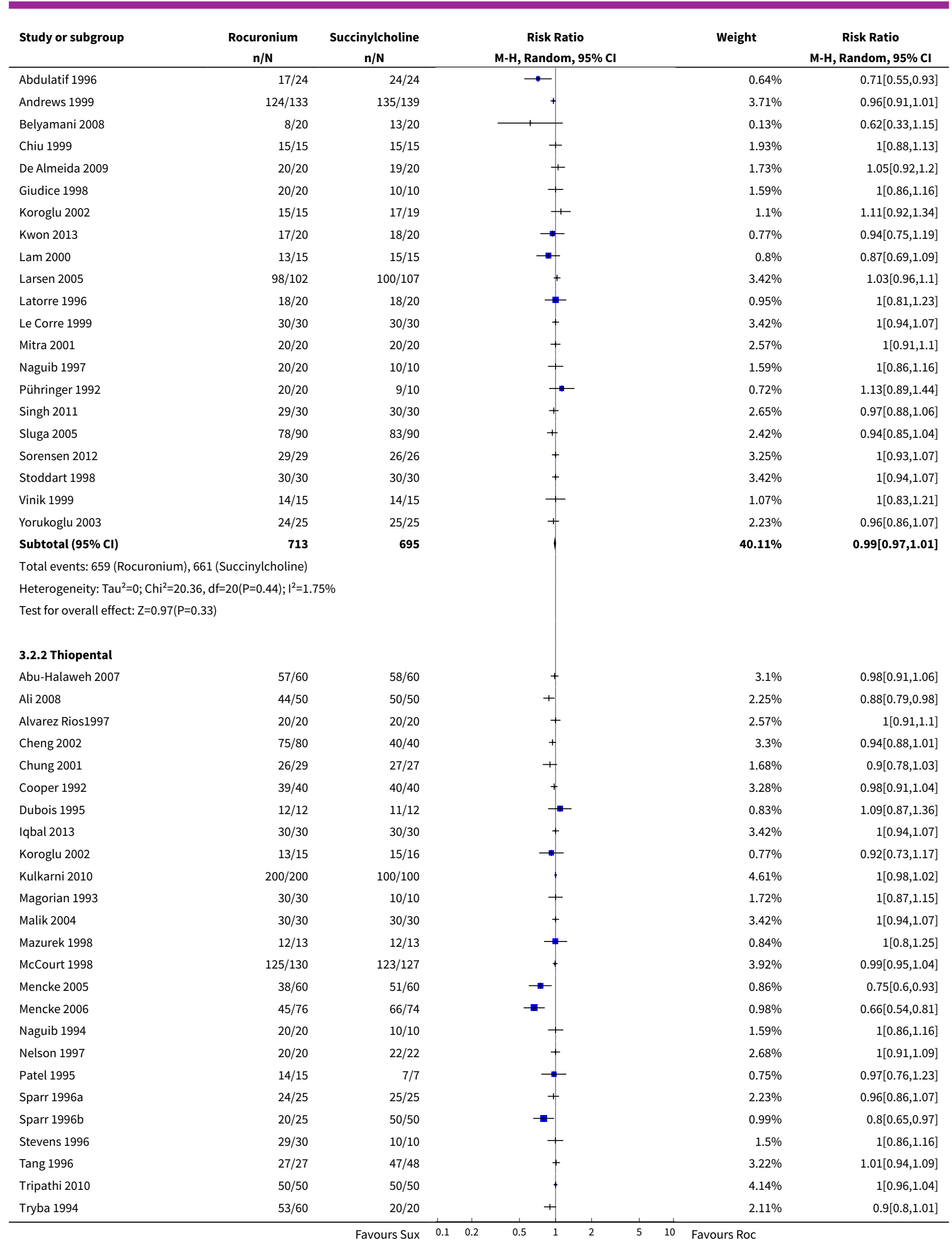




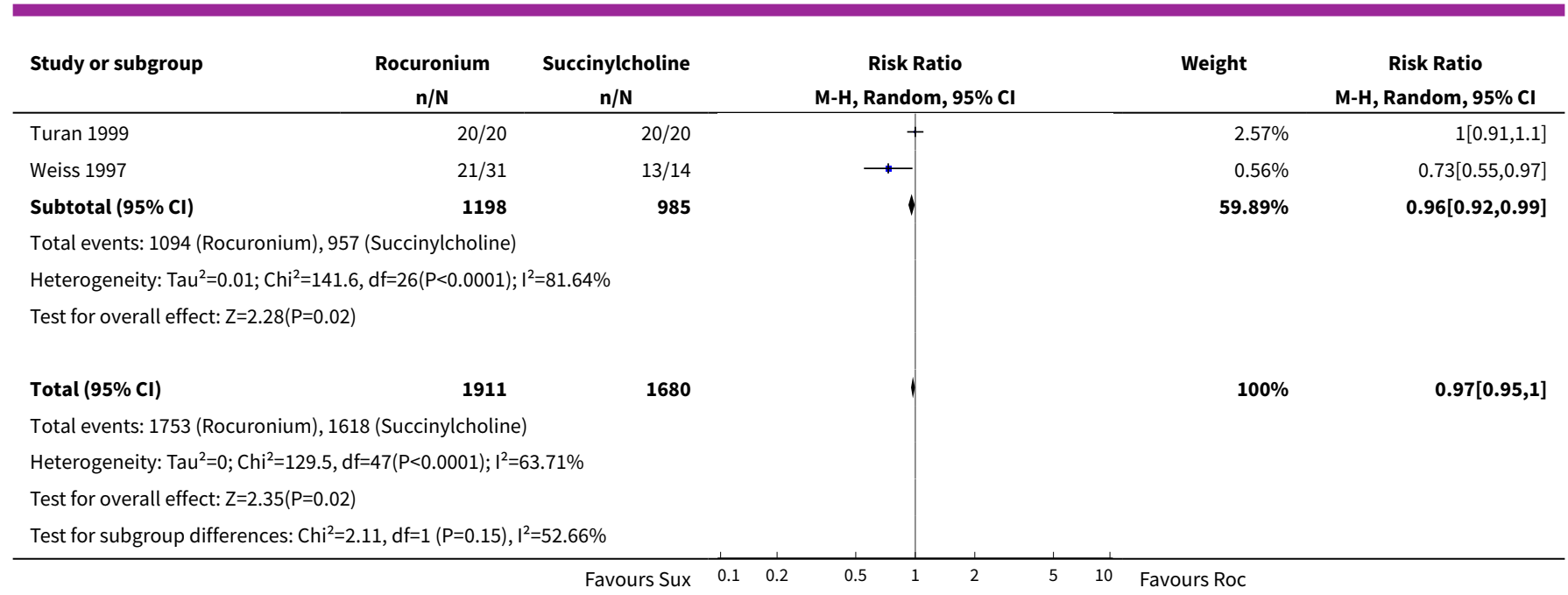

Comparison 4. Rocuronium versus succinylcholine with narcotic

\begin{tabular}{lllll}
\hline Outcome or subgroup title & $\begin{array}{l}\text { No. of } \\
\text { studies }\end{array}$ & $\begin{array}{l}\text { No. of } \\
\text { partici- } \\
\text { pants }\end{array}$ & Statistical method & Effect size \\
\hline $\begin{array}{l}1 \text { Excellent versus other intubation } \\
\text { outcomes }\end{array}$ & 34 & 2292 & Risk Ratio (M-H, Random, 95\% Cl) & $0.85[0.78,0.93]$ \\
\hline 1.1 Propofol Induction & 17 & 992 & Risk Ratio (M-H, Random, 95\% Cl) & $0.89[0.78,1.01]$ \\
\hline 1.2 Thiopental Induction & 17 & 1300 & Risk Ratio (M-H, Random, 95\% Cl) & $0.82[0.73,0.92]$ \\
\hline $\begin{array}{l}\text { 2 Acceptable versus suboptimal intu- } \\
\text { bation conditions }\end{array}$ & 32 & 2193 & Risk Ratio (M-H, Random, 95\% Cl) & $0.97[0.94,1.00]$ \\
\hline 2.1 Propofol Induction & 16 & 952 & Risk Ratio (M-H, Random, 95\% Cl) & $0.99[0.96,1.02]$ \\
\hline 2.2 Thiopental Induction & 16 & 1241 & Risk Ratio (M-H, Random, 95\% Cl) & $0.95[0.90,1.00]$ \\
\hline
\end{tabular}

\section{Analysis 4.1. Comparison 4 Rocuronium versus succinylcholine with narcotic, Outcome 1 Excellent versus other intubation outcomes.}

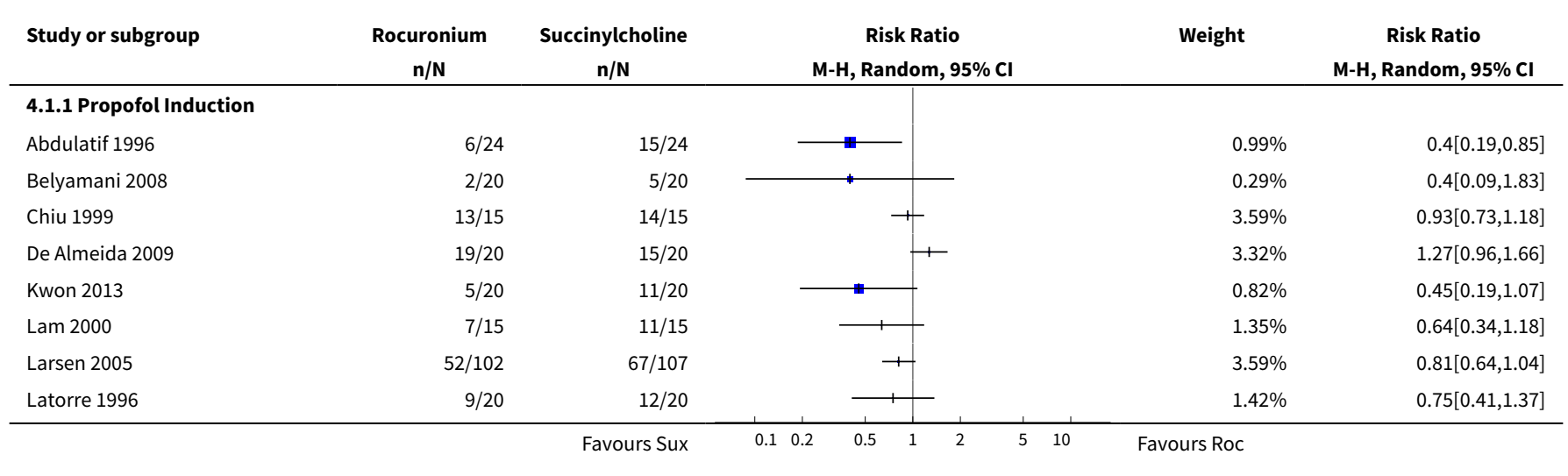




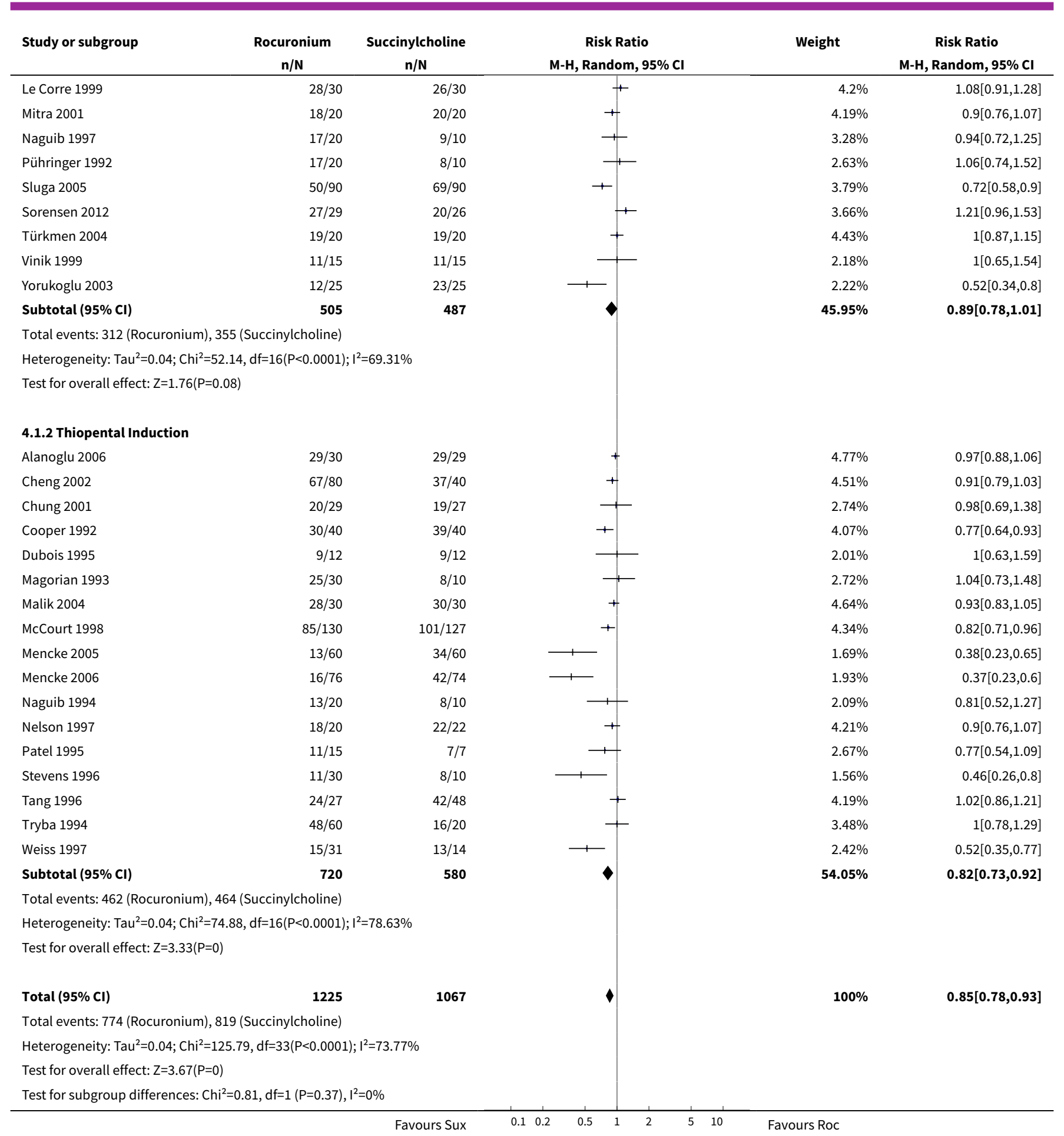


Analysis 4.2. Comparison 4 Rocuronium versus succinylcholine with narcotic, Outcome 2 Acceptable versus suboptimal intubation conditions.

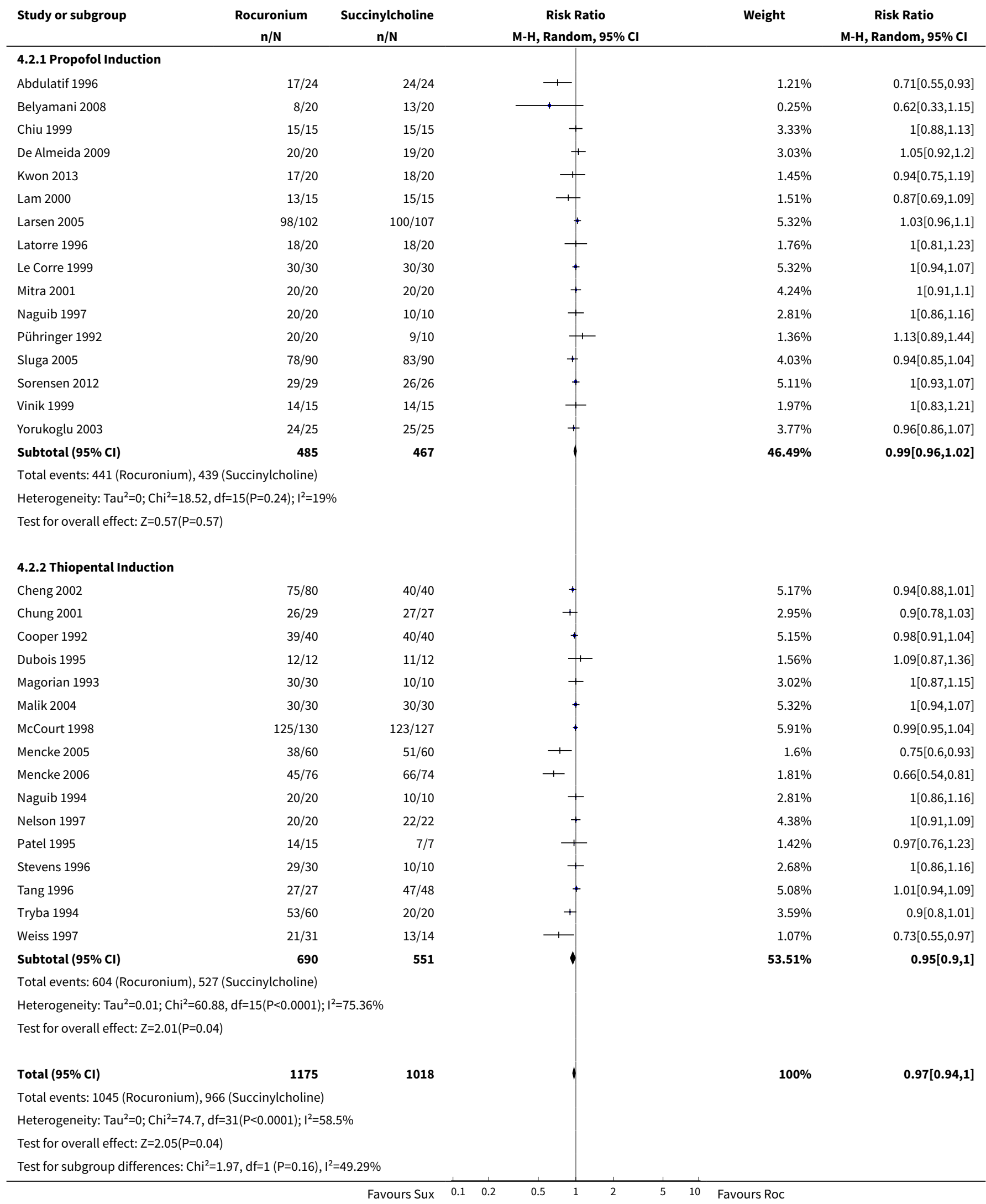


Comparison 5. Rocuronium versus succinylcholine without narcotic

\begin{tabular}{|c|c|c|c|c|}
\hline Outcome or subgroup title & $\begin{array}{l}\text { No. of } \\
\text { studies }\end{array}$ & $\begin{array}{l}\text { No. of } \\
\text { partici- } \\
\text { pants }\end{array}$ & Statistical method & Effect size \\
\hline $\begin{array}{l}1 \text { Excellent versus other intuba- } \\
\text { tion conditions }\end{array}$ & 15 & 1428 & Risk Ratio (M-H, Random, 95\% Cl) & $0.85[0.76,0.95]$ \\
\hline 1.1 Propofol Induction & 4 & 426 & Risk Ratio (M-H, Random, 95\% Cl) & $0.95[0.85,1.06]$ \\
\hline 1.2 Thiopental Induction & 12 & 1002 & Risk Ratio (M-H, Random, 95\% Cl) & $0.80[0.69,0.94]$ \\
\hline $\begin{array}{l}2 \text { Acceptable versus suboptimal } \\
\text { intubation conditions }\end{array}$ & 14 & 1368 & Risk Ratio (M-H, Random, 95\% Cl) & $0.98[0.95,1.01]$ \\
\hline 2.1 Propofol Induction & 4 & 426 & Risk Ratio (M-H, Random, 95\% Cl) & $0.98[0.94,1.02]$ \\
\hline 2.2 Thiopental Induction & 11 & 942 & Risk Ratio (M-H, Random, 95\% Cl) & $0.98[0.94,1.02]$ \\
\hline
\end{tabular}

\section{Analysis 5.1. Comparison 5 Rocuronium versus succinylcholine without narcotic, Outcome 1 Excellent versus other intubation conditions.}

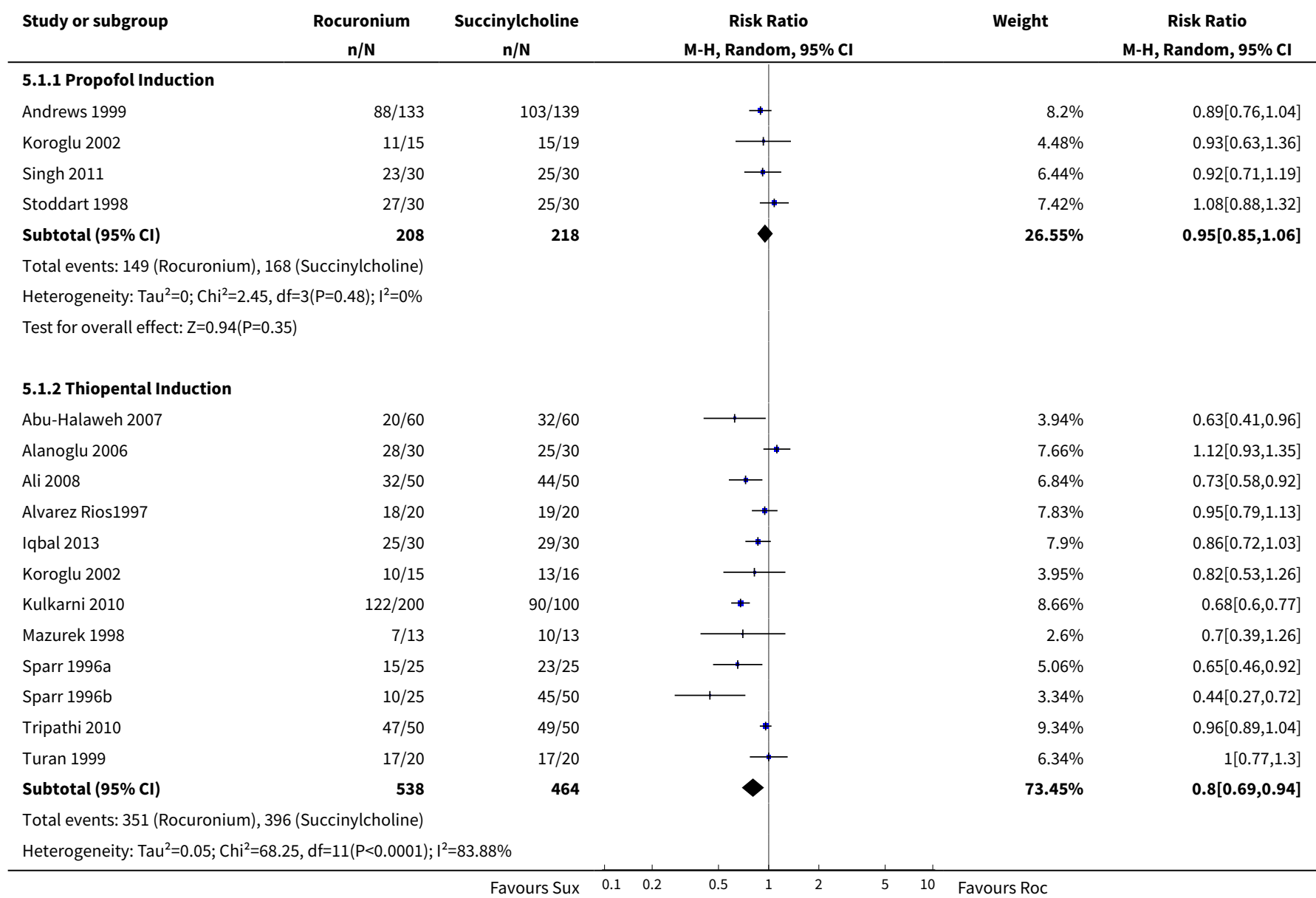




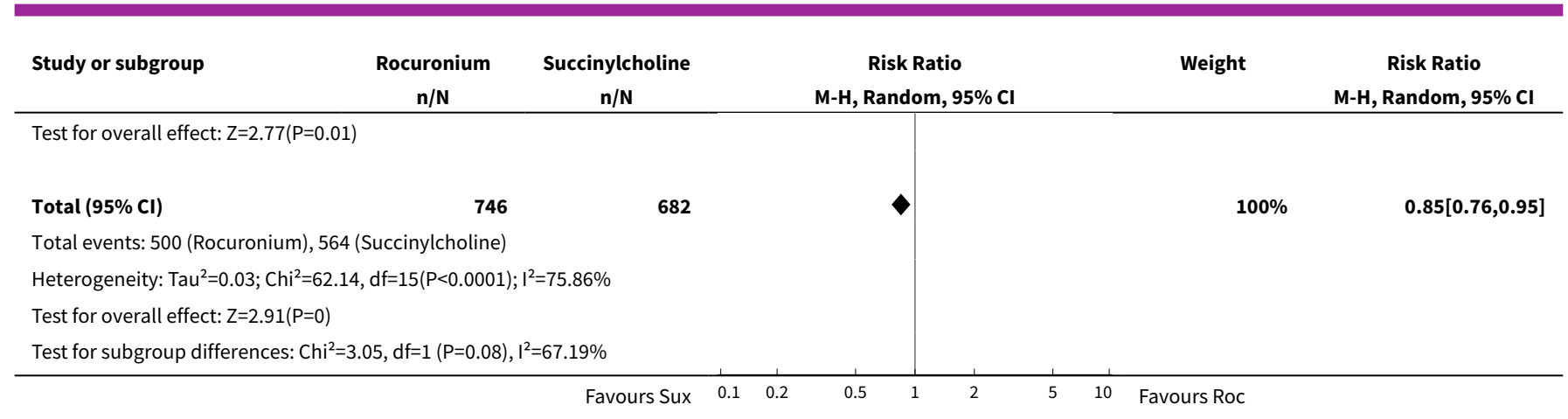

Analysis 5.2. Comparison 5 Rocuronium versus succinylcholine without narcotic, Outcome 2 Acceptable versus suboptimal intubation conditions.

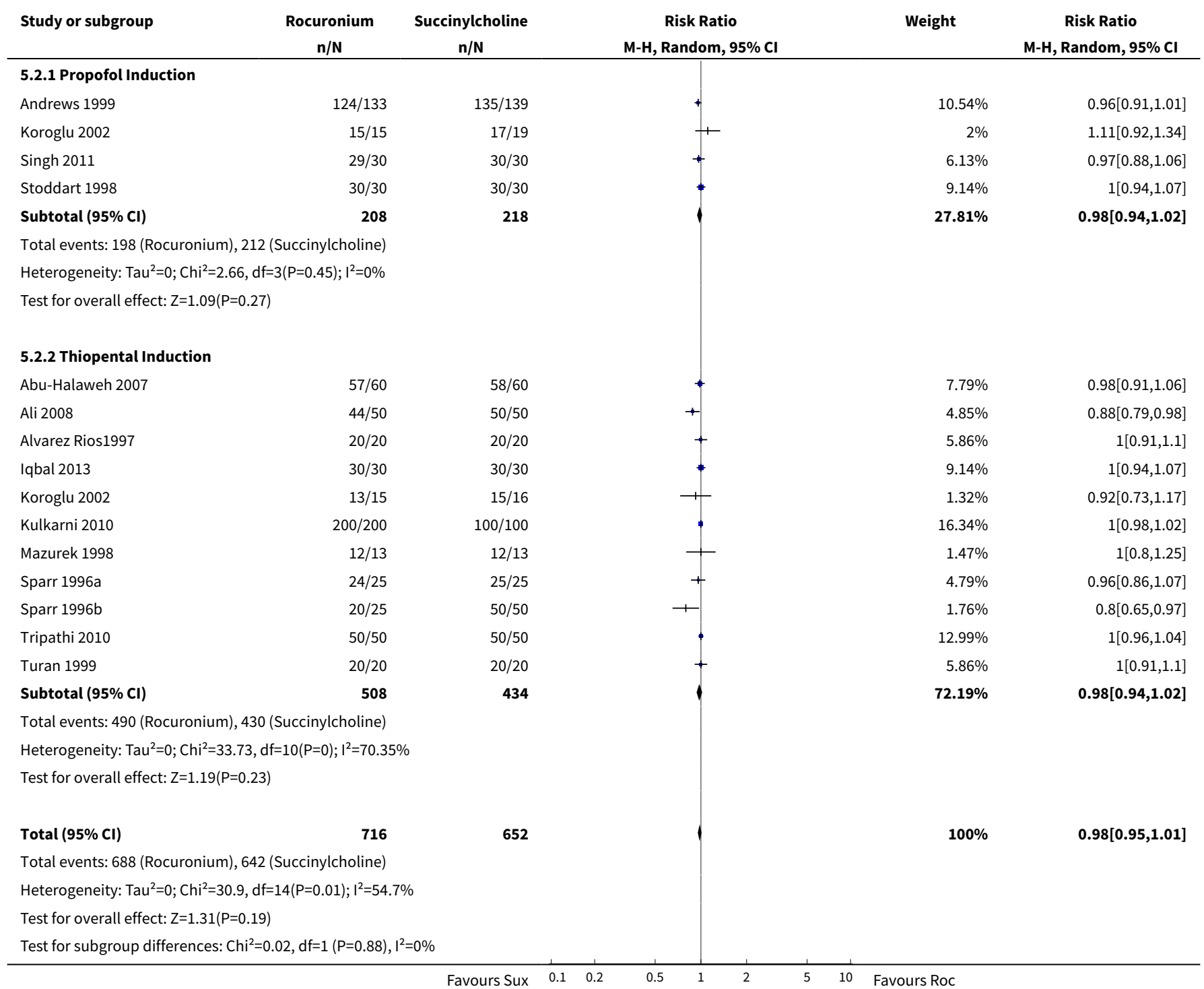


Comparison 6. Comparison of children and adults

\begin{tabular}{lllll}
\hline Outcome or subgroup title & $\begin{array}{l}\text { No. of } \\
\text { studies }\end{array}$ & $\begin{array}{l}\text { No. of } \\
\text { partici- } \\
\text { pants }\end{array}$ & Statistical method & Effect size \\
\hline $\begin{array}{l}1 \text { Excellent versus other intubation } \\
\text { conditions }\end{array}$ & 50 & 4151 & Risk Ratio (M-H, Random, 95\% Cl) & $0.86[0.80,0.91]$ \\
\hline $\begin{array}{l}1.1 \text { Adults } \\
1.2 \text { Children }\end{array}$ & 45 & 3615 & Risk Ratio (M-H, Random, 95\% Cl) & $0.85[0.80,0.92]$ \\
\hline $\begin{array}{l}2 \text { Acceptable versus suboptimal intu- } \\
\text { bation conditions }\end{array}$ & 48 & 3992 & Risk Ratio (M-H, Random, 95\% Cl) & $0.97[0.95,0.99]$ \\
\hline $\begin{array}{l}2.1 \text { Adults } \\
2.2 \text { Children }\end{array}$ & 43 & 3456 & Risk Ratio (M-H, Random, 95\% Cl) & $0.97[0.95,0.99]$ \\
\hline
\end{tabular}

Analysis 6.1. Comparison 6 Comparison of children and adults, Outcome 1 Excellent versus other intubation conditions.

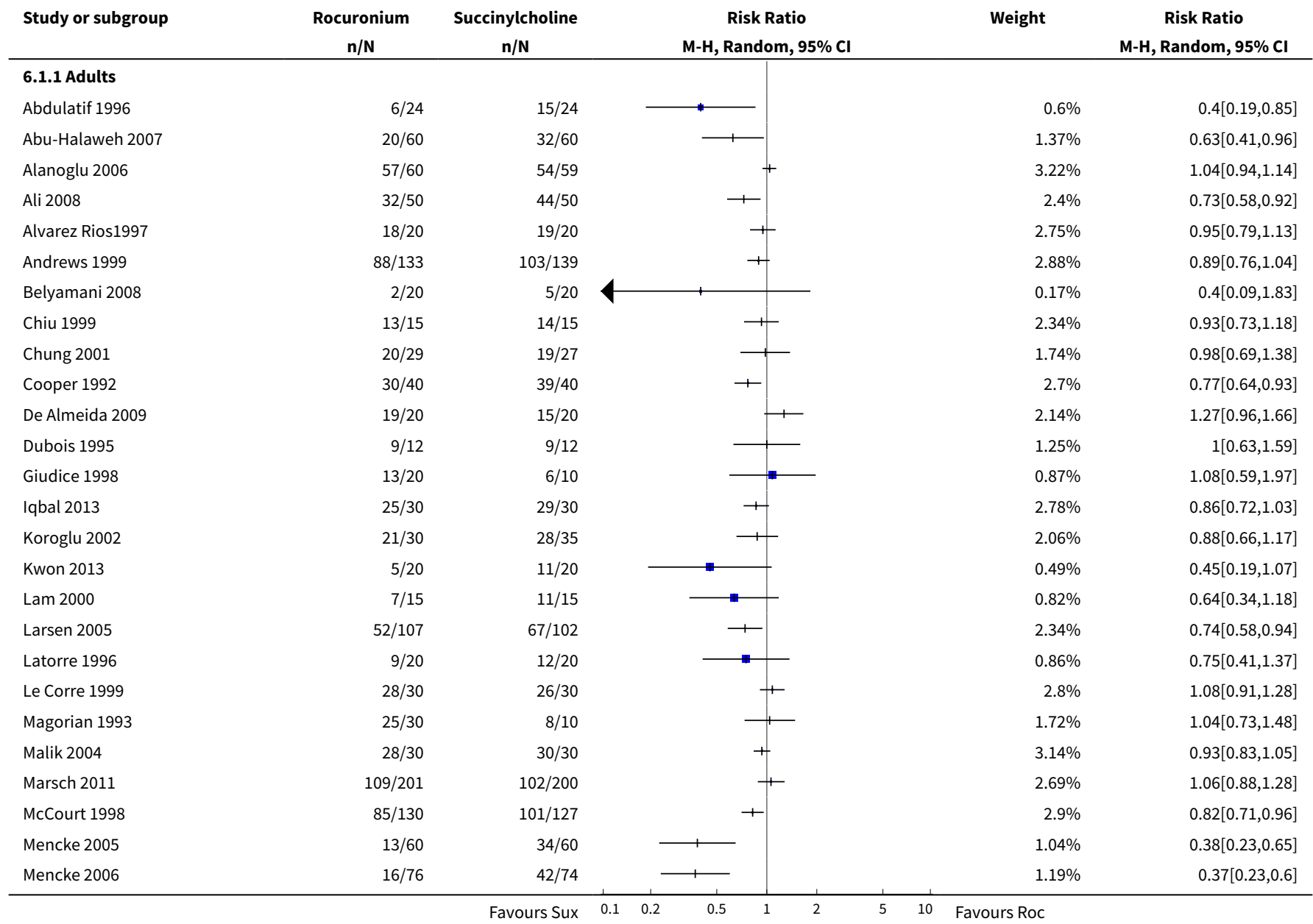




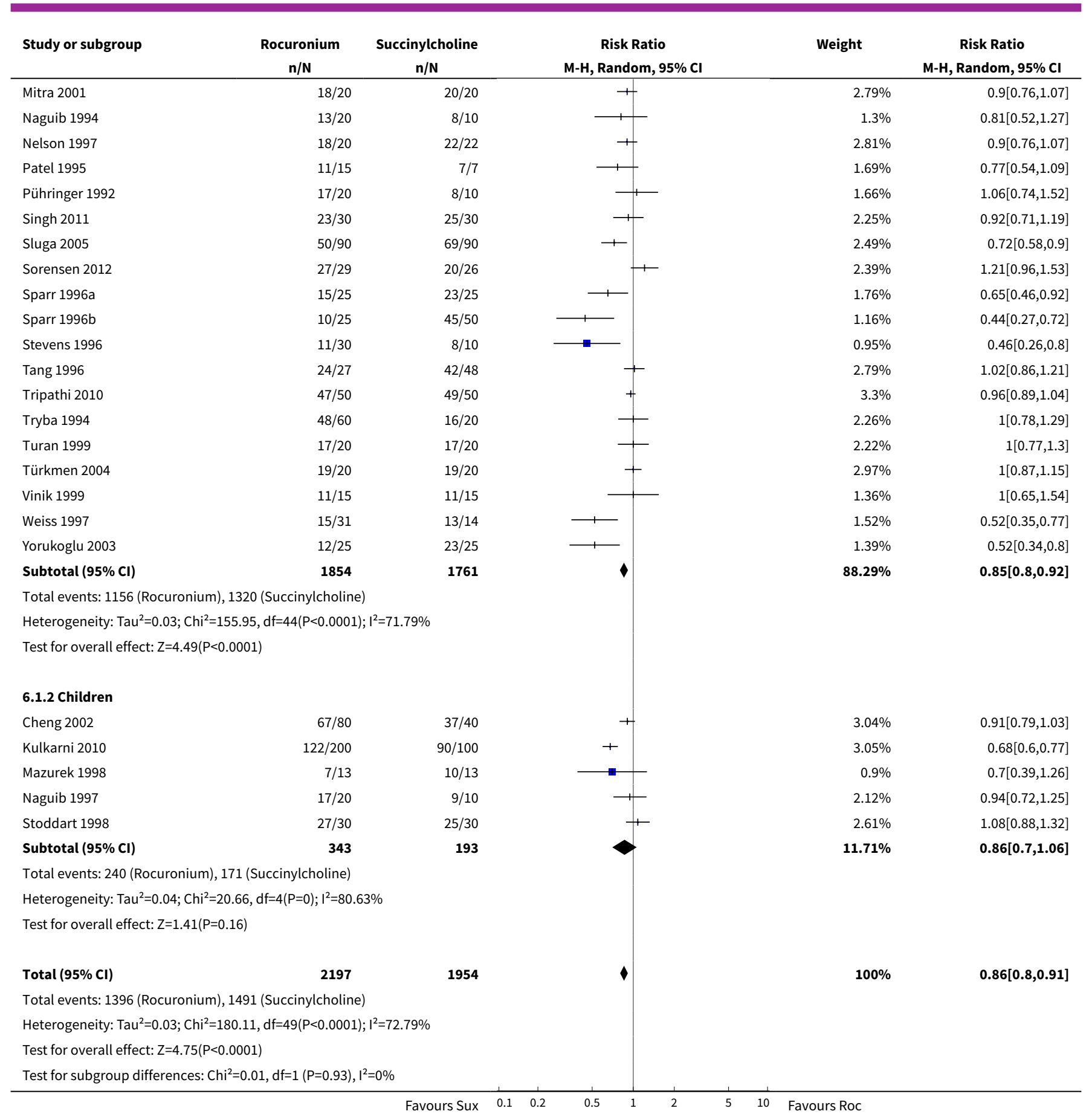

Analysis 6.2. Comparison 6 Comparison of children and adults, Outcome 2 Acceptable versus suboptimal intubation conditions.

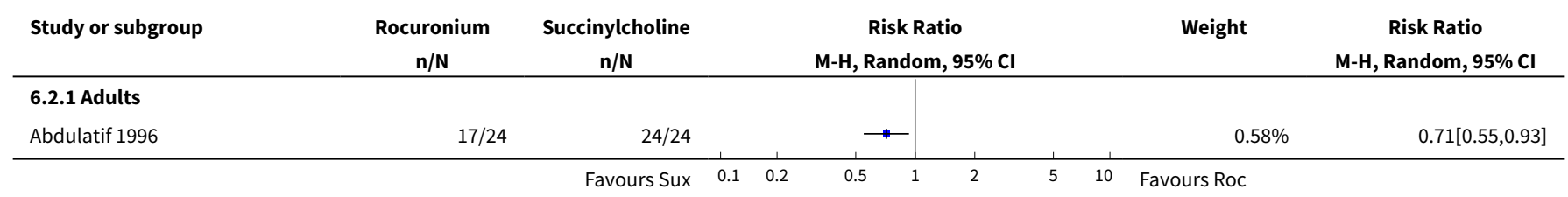




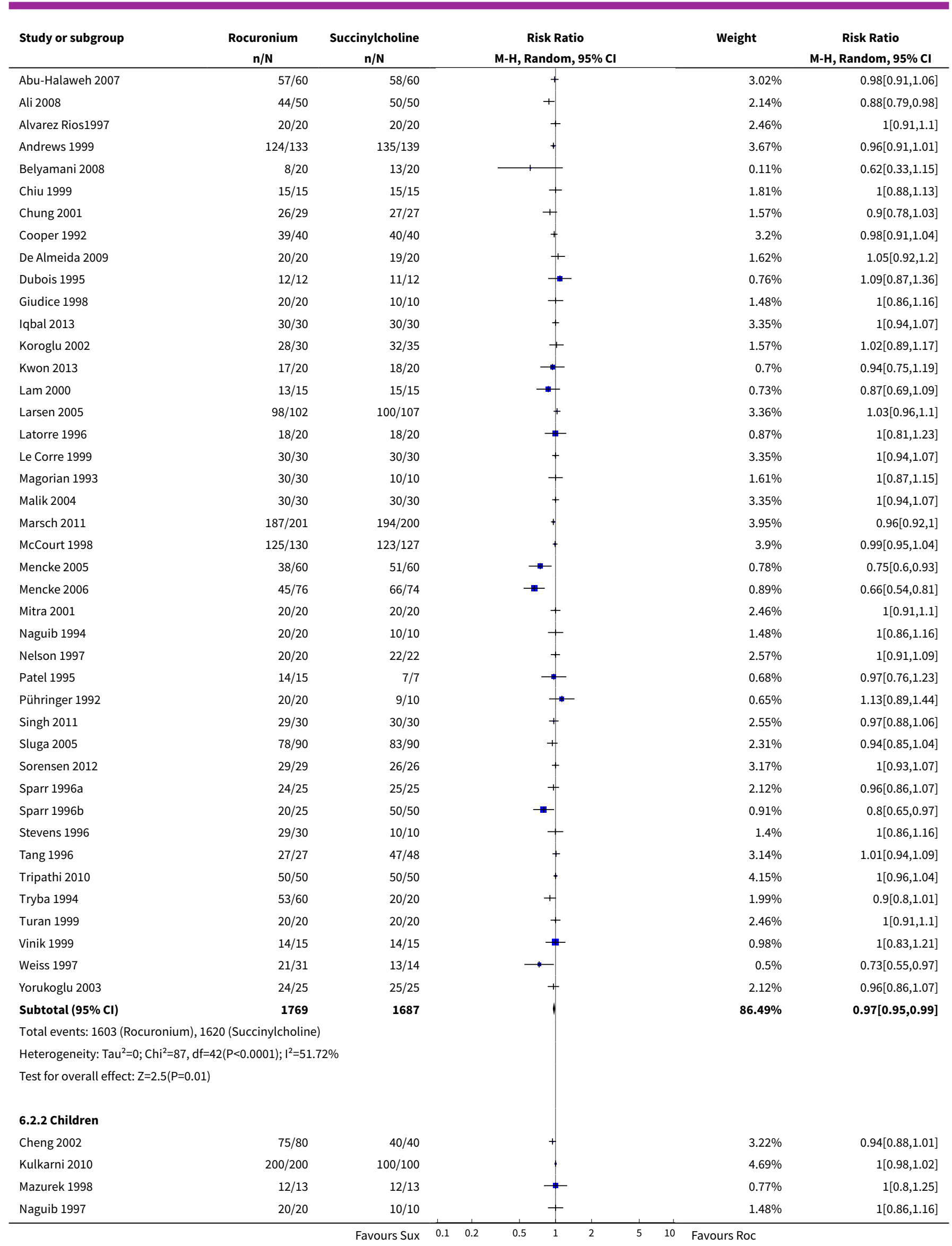




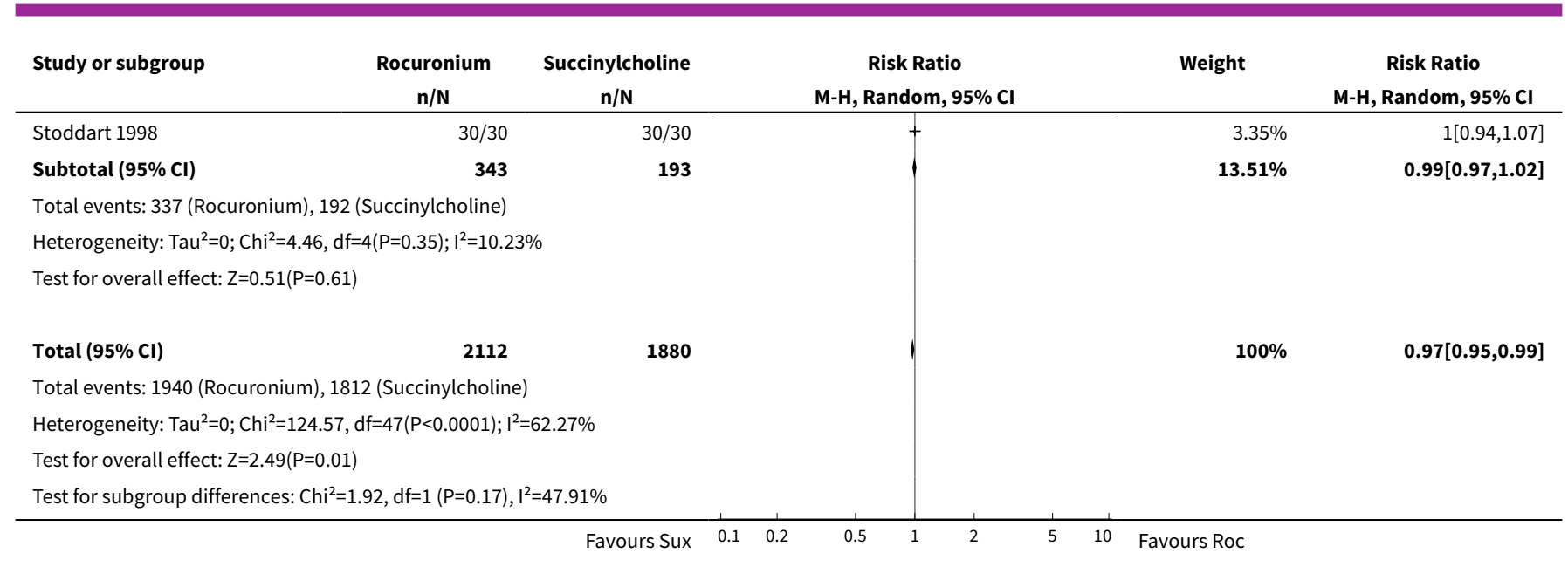

Comparison 7. Rocuronium versus succinylcholine in emergency intubation

\begin{tabular}{llllll}
\hline Outcome or subgroup title & $\begin{array}{l}\text { No. of } \\
\text { studies }\end{array}$ & $\begin{array}{l}\text { No. of } \\
\text { partici- } \\
\text { pants }\end{array}$ & Statistical method & Effect size \\
\hline 1 Excellent versus other intubation conditions & 5 & 1073 & Risk Ratio (M-H, Random, 95\% Cl) & $0.84[0.73,0.98]$ \\
\hline $\begin{array}{l}2 \text { Acceptable versus suboptimal intubation } \\
\text { conditions }\end{array}$ & 5 & 1073 & Risk Ratio (M-H, Random, 95\% Cl) & $0.98[0.96,1.01]$ \\
\hline
\end{tabular}

Analysis 7.1. Comparison 7 Rocuronium versus succinylcholine in emergency intubation, Outcome 1 Excellent versus other intubation conditions.

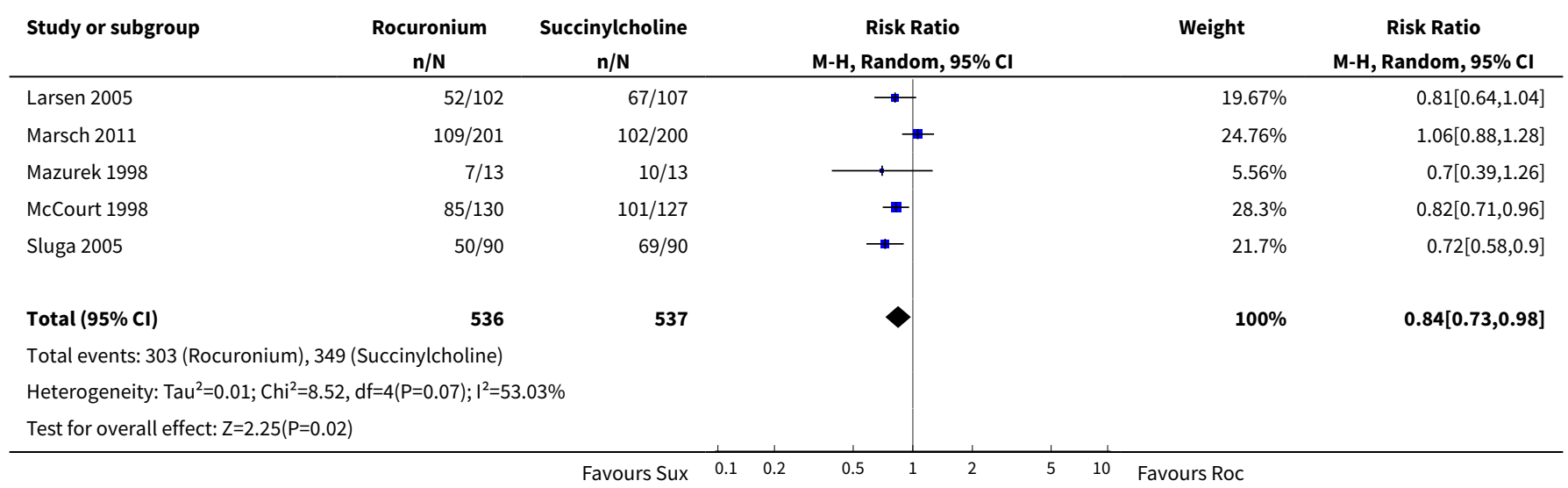


Analysis 7.2. Comparison 7 Rocuronium versus succinylcholine in emergency intubation, Outcome 2 Acceptable versus suboptimal intubation conditions.

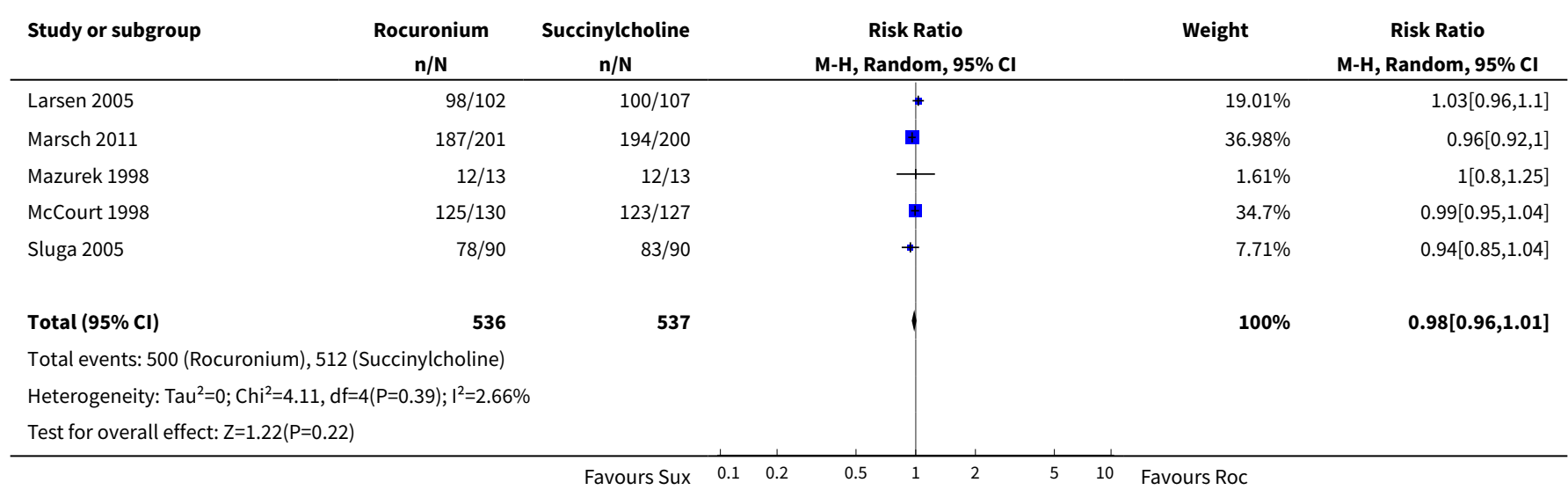

Comparison 8. Rocuronium versus succinylcholine by blinding of outcome assessment

\begin{tabular}{|c|c|c|c|c|}
\hline Outcome or subgroup title & $\begin{array}{l}\text { No. of } \\
\text { studies }\end{array}$ & $\begin{array}{l}\text { No. of } \\
\text { partici- } \\
\text { pants }\end{array}$ & Statistical method & Effect size \\
\hline $\begin{array}{l}1 \text { Excellent versus other intubation } \\
\text { conditions }\end{array}$ & 50 & 4151 & Risk Ratio (M-H, Random, 95\% Cl) & $0.86[0.81,0.92]$ \\
\hline 1.1 Low Risk & 21 & 1880 & Risk Ratio (M-H, Random, 95\% Cl) & $0.83[0.75,0.92]$ \\
\hline 1.2 Unclear Risk & 4 & 229 & Risk Ratio (M-H, Random, 95\% Cl) & $0.93[0.72,1.18]$ \\
\hline 1.3 High Risk & 25 & 2042 & Risk Ratio (M-H, Random, 95\% Cl) & $0.88[0.80,0.96]$ \\
\hline $\begin{array}{l}2 \text { Acceptable versus suboptimal in- } \\
\text { tubation conditions }\end{array}$ & 48 & 3992 & Risk Ratio (M-H, Random, 95\% Cl) & $0.97[0.95,0.99]$ \\
\hline 2.1 Low Risk & 23 & 1970 & Risk Ratio (M-H, Random, 95\% Cl) & $0.97[0.94,1.00]$ \\
\hline 2.2 Unclear Risk & 3 & 110 & Risk Ratio (M-H, Random, 95\% Cl) & $0.99[0.92,1.07]$ \\
\hline 2.3 High Risk & 22 & 1912 & Risk Ratio (M-H, Random, 95\% Cl) & $0.97[0.94,1.00]$ \\
\hline
\end{tabular}

Analysis 8.1. Comparison 8 Rocuronium versus succinylcholine by blinding of outcome assessment, Outcome 1 Excellent versus other intubation conditions.

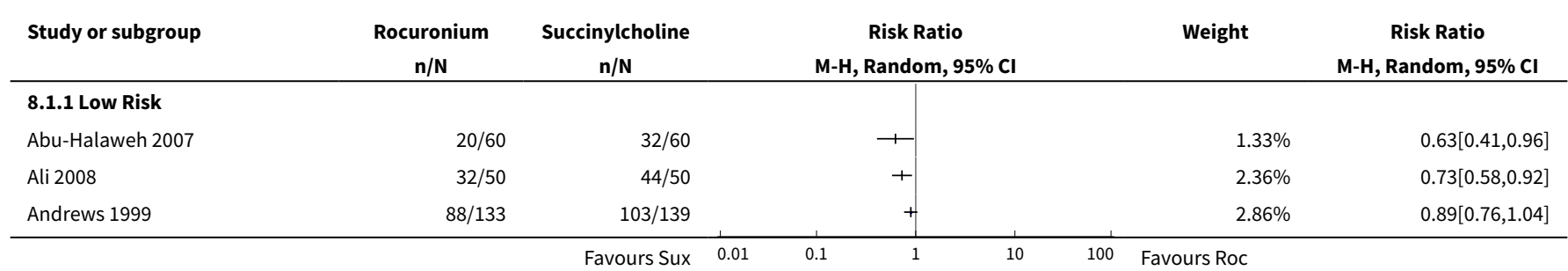




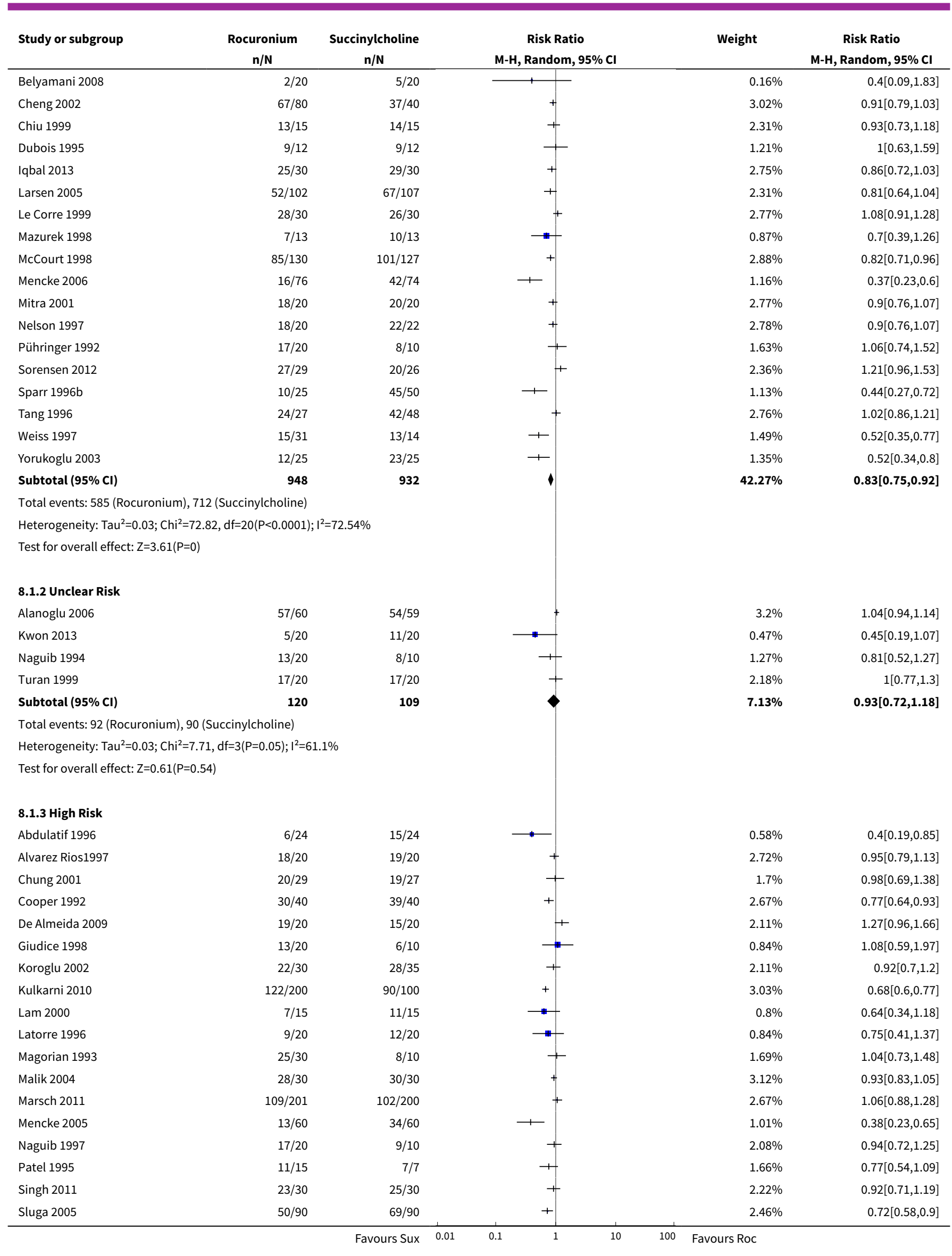




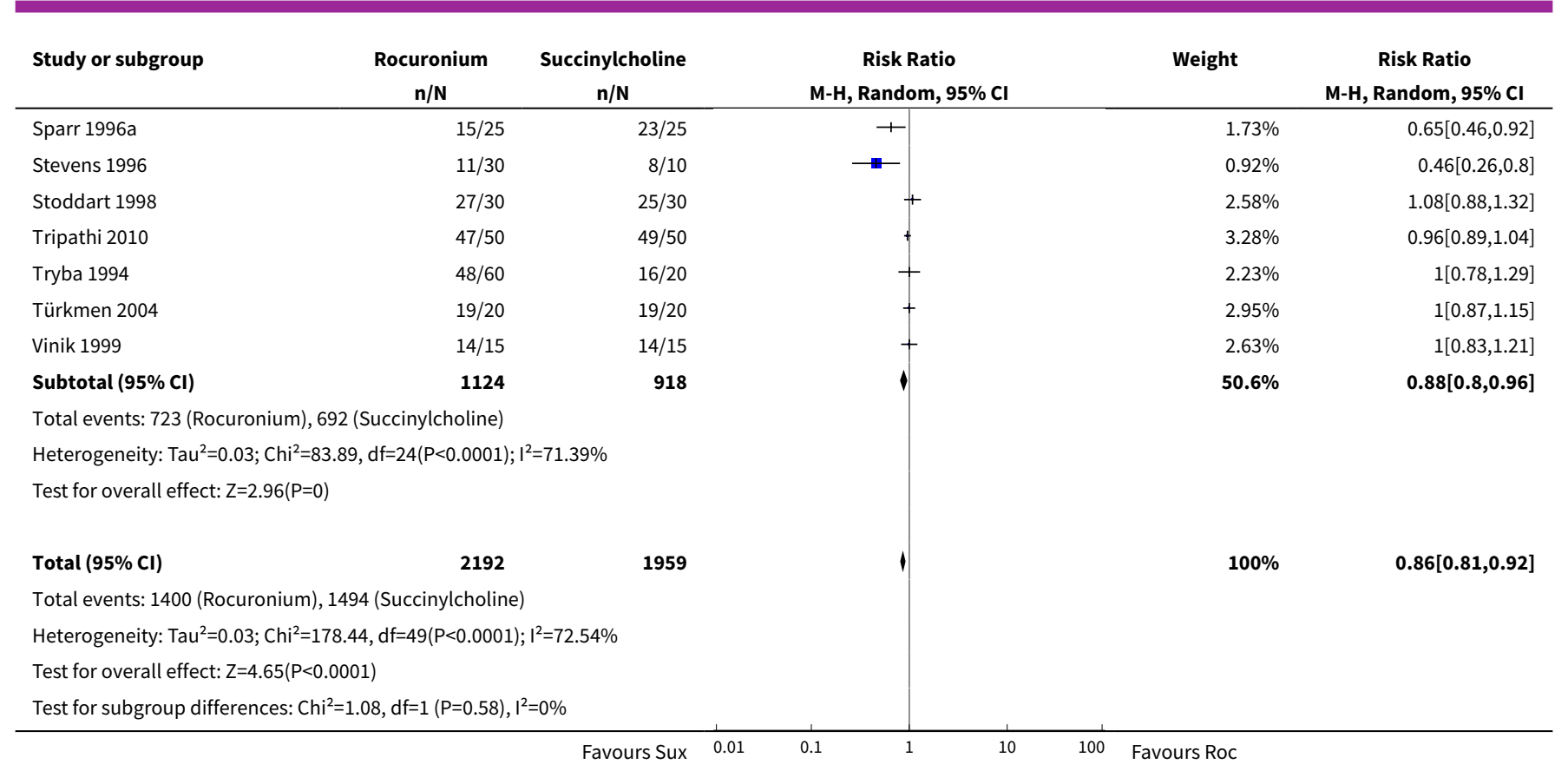

Analysis 8.2. Comparison 8 Rocuronium versus succinylcholine by blinding of outcome assessment, Outcome 2 Acceptable versus suboptimal intubation conditions.

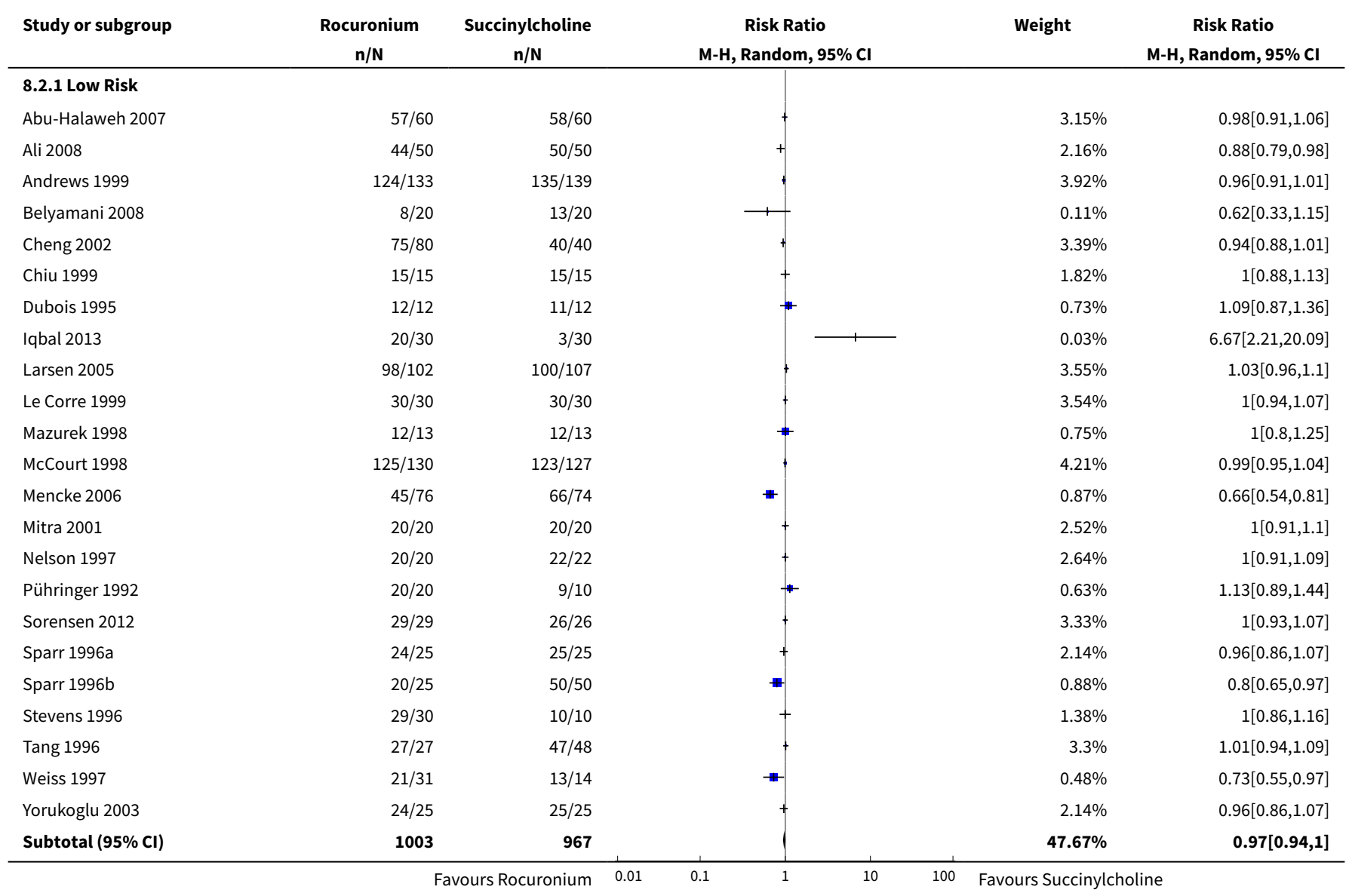




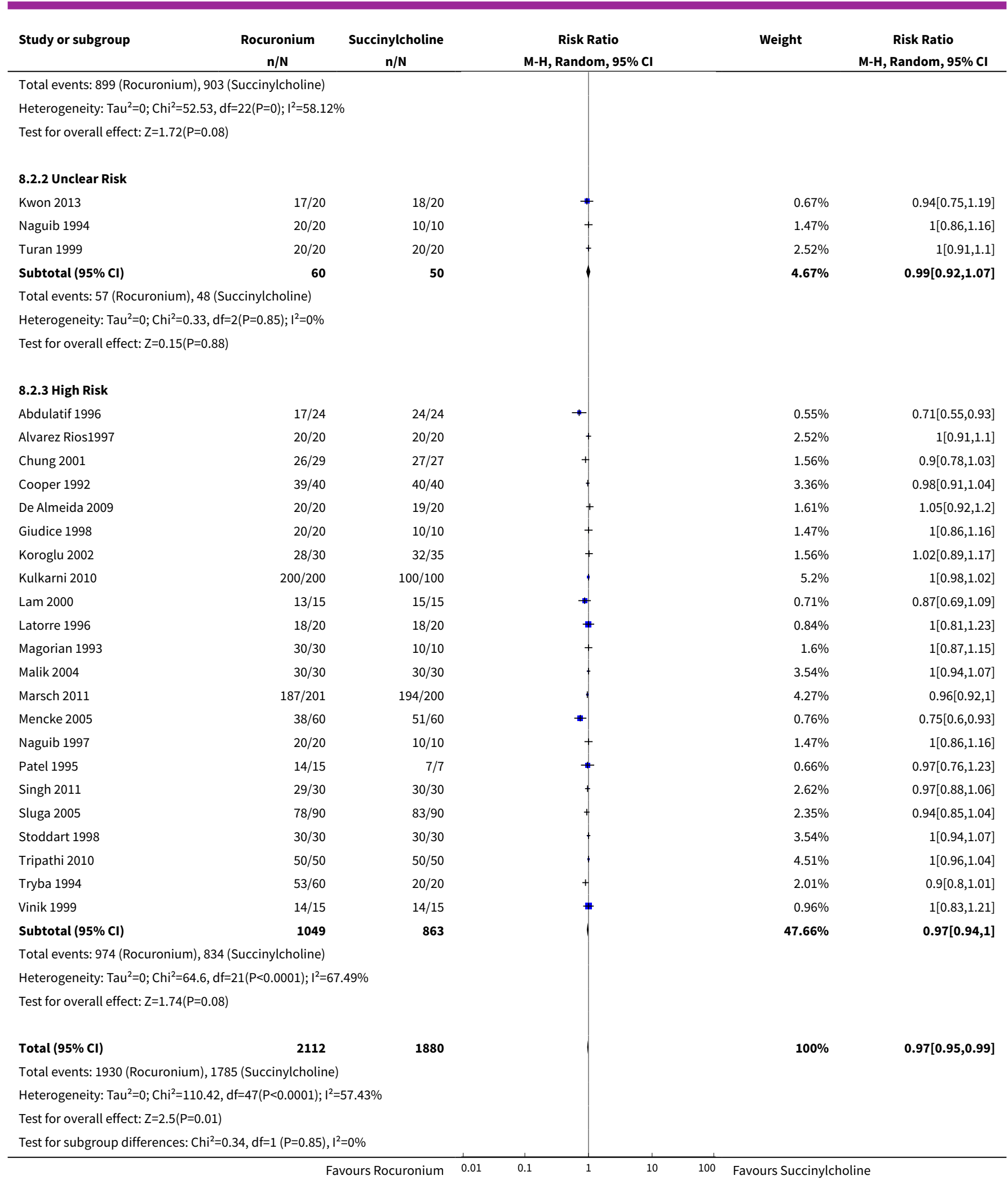

\section{ADDITIONAL TABLES}


Table 1. Intubating conditions

\begin{tabular}{llll}
\hline Score & Ease of laryngoscopy & Vocal cords & Intubation response \\
\hline 1. Excellent & Good & Open & None \\
\hline 2. Good & Fair & Open & Diaphragmatic movement \\
\hline 3. Poor & Difficult & Movement & Moderate coughing \\
\hline 4. Impossible & Poor & Closed & Severe coughing or bucking \\
\hline
\end{tabular}

\section{AP PE N D I C E S}

\section{Appendix 1. MEDLINE (via OVID) (1966 to February 14 2015)}

1. succinylcholine/ or succinylcholine.mp. or suxamethonium.mp. or succinyldicholine.mp. or anectine.mp. or quelicin.mp. or sucostrin.mp. or celocurine.mp. or deliclin.mp. or listenon.mp. or lysthenon.mp. or myorelaxin.mp. or succicuran.mp.

2. rocuronium. af. or zemuron.mp. or org $9426 . \mathrm{mp}$.

3. neuromuscular blocker/ or neuromuscular block\$.mp. or rapid sequence induction.mp. or rsi.mp. or intubat\$.mp. or anesthesia/ or anesthesia.mp.

4. 1 and 2 and 3

\section{Appendix 2. EMBASE (via OVID) (1988 to February 14 2015)}

1. succinylcholine/ or suxamethonium iodide/ or succinylcholine.mp. or suxamethonium.mp. or succinyldicholine.mp. or anectine.mp. or quelicin.mp. or sucostrin.mp. or celocurine.mp. or deliclin.mp. or listenon.mp. or lysthenon.mp. or myorelaxin.mp. or succicuran.mp.

2. rocuronium/ or rocuronium. af. or zemuron. mp. or org 9426. mp.

3 neuromuscular blocking agent/ or neuromuscular block\$.mp. or rapid sequence induction.mp. or rsi.mp. or intubat\$.mp. or general anesthesia/ or intubation/ or endotracheal intubation/ or rapid sequence induction.mp. or rsi.mp.

4. 1 and 2 and 3

5. (randomized-controlled-trial/or randomization/or controlled-study/or multicenter-study/or phase-3-clinical-trial/or phase-4-clinicaltrial/ or double-blind-procedure/ or single-blind-procedure/ or (random or cross?over ${ }^{\star}$ or factorial ${ }^{\star}$ or placebo* or volunteer ${ }^{\star}$.mp. or ((singl* or doubl* or trebl* or tripl $\left.l^{\star}\right)$ adj3 (blind* or mask $\left.{ }^{\star}\right)$ ).ti,ab.) not (animals not (humans and animals)).sh.

6. 4 and 5

\section{Appendix 3. CENTRAL, the Cochrane Library (February 2015 Issue 2)}

\#1 MeSH descriptor Succinylcholine explode all trees

\#2 succinylcholin* or suxamethonium or succinyldicholin* or anectine or quelicin or sucostrin or celocurine or deliclin or listenon or lysthenon or myorelaxin or succicuran

\#3 (\#1 OR \#2)

\#4 rocuronium or zemuron

\#5 org 9426

\#6 (ROCURONIUM) or (ROCURONIUM-INDUCED)

\#7 (\#4 OR \#5 OR \#6)

\#8 MeSH descriptor Neuromuscular Blocking Agents explode all trees

\#9 MeSH descriptor Neuromuscular Blockade explode all trees

\#10 neuromuscular near block

\#11 (\#8 OR \#9 OR \#10)

\#12 (\#3 AND \#7 AND \#11)

\section{WHAT'S NEW}

\begin{tabular}{lll}
\hline Date & Event & Description \\
\hline 15 October 2015 & $\begin{array}{l}\text { New citation required but conclusions } \\
\text { have not changed }\end{array}$ & $\begin{array}{l}\text { New authors (DT, EN) joined the team. Conclusions for the study } \\
\text { were not changed with inclusion of new citations. Methods now }\end{array}$ \\
\hline
\end{tabular}




\begin{tabular}{lll}
\hline Date & Event & Description \\
\hline & & $\begin{array}{l}\text { include a 'Risk of bias' table, 'Summary of findings' table and } \\
\text { GRADE assessment. }\end{array}$ \\
\hline 15 October 2015 & New search has been performed & $\begin{array}{l}\text { We ran the search to Week 2 of February 2015. We identified 13 } \\
\text { new trials, of which 11 were incorporated into the meta-analysis. } \\
\text { Two trials awaiting translation from the previous update were } \\
\text { translated and included in this review. }\end{array}$ \\
\hline
\end{tabular}

\section{HIST O R Y}

Protocol first published: Issue 4, 2000

Review first published: Issue 1, 2003

\begin{tabular}{lll}
\hline Date & Event & Description \\
\hline 20 August 2007 & $\begin{array}{l}\text { New citation required and conclusions } \\
\text { have changed }\end{array}$ & $\begin{array}{l}\text { Substantive amendment. We reran our searches until June 2007. } \\
\text { We found 18 new studies and included 11. The conclusions } \\
\text { changed. }\end{array}$ \\
\hline 19 August 2007 & New search has been performed & The review is substantially updated \\
\hline
\end{tabular}

\section{CONTRIBUTIONS OF AUTHORS}

Diem TT Tran (DT), Ethan K Newton (EN), Victoria AH Mount (VM), Jacques S Lee (JL), George A Wells (GW), Jeffrey J Perry (JJP)

Conceiving the review: JJP

Co-ordinating the review: JJP

Undertaking manual searches: JJP, VM EN

Screening search results: JJP, JL, VM, EN, DT

Organizing retrieval of papers: JJP, VM, EN, DT

Screening retrieved papers against inclusion criteria: JJP, JL, VM, EN, DT

Appraising quality of papers: JJP, JL, VM, EN, DT

Abstracting data from papers: JJP, JL, VM, EN, DT

Data management for the review: JJP, DT

Entering data into Review Manager: JJP, VM, EN, DT

Analysis of Data: JJP, JL, VS, GW, DT

Interpretation of data: JJP, VS, GW, DT

Statistical analysis: JJP, GW, DT

Writing the review: JJP, JL, VM, GW, DT

Securing funding for the review: JJP

Guarantor for the review (one author): JJP

Responsible for reading and checking review before submission: JJP, DT

\section{DECLARATIONS OF INTEREST}

Diem TT Tran: none known

Ethan K Newton: none known

Victoria AH Mount: none known

Jacques S Lee: none known

George A Wells: none known

Jeffrey J Perry: none known 


\section{SOURCES OF SUPPORT}

\section{Internal sources}

- No sources of support supplied

\section{External sources}

- Canadian Association of Emergency Physicians, Canada.

\section{DIFFERENCES BETWEEN PROTOCOL AND REVIEW}

We added a subgroup analysis based on detection bias after the meta-analysis was performed, to try to identify a source for the high statistical heterogeneity.

\section{NOTES}

August 2015: Methods now include a 'Risk of bias' table, a 'Summary of findings' table and GRADE assessment.

\section{INDEX TERMS}

\section{Medical Subject Headings (MeSH)}

Androstanols [ ${ }^{\star}$ administration \& dosage]; Intubation, Intratracheal [ ${ }^{*}$ methods]; Neuromuscular Depolarizing Agents [ ${ }^{*}$ administration \& dosage] [adverse effects]; Neuromuscular Nondepolarizing Agents [*administration \& dosage] [adverse effects]; Propofol [administration \& dosage]; Randomized Controlled Trials as Topic; Rocuronium; Succinylcholine [ ${ }^{\star}$ administration \& dosage] [adverse effects]

\section{MeSH check words}

Humans 